\author{
Universidade de São Paulo \\ Instituto de Física \\ Instituto de Química \\ Instituto de Biociências \\ Faculdade de Educação
}

\title{
O PENSAMENTO EM AÇÃO DOS ALUNOS NA RESOLUÇÃO DE UM PROBLEMA EXPERIMENTAL DE FÍSICA
}

\author{
José Eduardo Biasoto
}

Orientadora: Profa. Dra Anna Maria Pessoa de Carvalho

Dissertação de mestrado apresentada ao Instituto de Física, ao Instituto de Química, ao Instituto de Biociências e a Faculdade de Educação da Universidade de São Paulo, para a obtenção do título de Mestre em Ensino de Ciências.

São Paulo 


\section{FICHA CATALOGRÁFICA}

\section{Preparada pelo Serviço de Biblioteca e Informação do Instituto de Física da Universidade de São Paulo}

Biasoto, José Eduardo

O pensamento em açẫo dos alunos na resoluçẫo de um problema experimental de física. - . Sẫo Paulo 2009

Mestrado (Dissertaçâo) - Universidade de São Paulo. Faculdade de Educaçâo, Instituto de Física, Instituto de

Química e Instituto de Biociências

Orientadora: Profa. Dra. Anna Maria Pessoa de Carvalho

Área de Concentraçăo: Ensino de Física

Unitermos: 1. Física (Estudo e ensino); 2. Laboratório aberto; 3 . Enculturação científica : 4. Alfabetizaçâo

científica; 5 . Atividades experimentais.

USP/IF/SBI-005/2010 


\section{Agradecimentos}

Ao final de uma jornada como esta, a quem devo agradecer? Certamente, algumas pessoas que deram grandes ou pequenas contribuições a este trabalho poderão não encontrar o seu nome nestas poucas linhas. A estes, o meu primeiro agradecimento, aliás, um duplo agradecimento: primeiro, um obrigado pela sua contribuição e depois um sincero obrigado pela compreensão por não ser citado, o que torna a sua contribuição mais nobre e sincera.

Eu só poderia começar estes agradecimentos pelos meus pais que me deram a oportunidade da vida e sem eles, eu não estaria aqui e muito menos este trabalho. Agradeço a todos os meus professores, também sem os quais eu não teria aprendido a ler, escrever, fazer contas, a gostar de física e sem isso, este trabalho também não existiria.

Como poderia me esquecer de meus colegas do LAPEF e do IFUSP que me enriqueceram pelo convívio, pelas conversas e discussões.

A todos vocês um muito obrigado.

Preciso agora agradecer às professoras Maria Lúcia e Maria Eunice pelas valiosas contribuições que deram na minha qualificação.

Agradeço à professora Daise por aceitar participar da banca e à Maria Cândida, sempre disposta a participar.

Neste ponto, apresenta-me um problema. Como agradecer à professora Anna Maria, por ter me aceito como orientando, pela sua paciência e pela sua dedicação. Com palavras, é pouco. A melhor forma que eu encontro é procurar aprender com seu exemplo e colocar em cada aula minha, em cada artigo ou trabalho um pouco do que aprendi com ela, todos os dias. À professora Anna Maria, o meu muito obrigado e respeito.

Agora, um agradecimento do fundo do meu coração à minha eterna namoradinha, pela sua paciência, compreensão e participação. 
Por fim, um agradecimento especial a quem me ensinou que prestar homenagens é dever de quem entendeu o respeito.

“A evolução é meta do Universo, é medida universal." Dr. Celso Charuri. 


\section{Resumo}

BIASOTO, J.E. O Pensamento Em Ação dos Alunos Na Resolução De Um Problema Experimental De Física, 2010. Dissertação (Mestrado) - Instituto de Física e Faculdade de Educação da Universidade de São Paulo (USP).

Na nossa pesquisa, procuramos analisar uma atividade didática experimental, na qual os alunos receberam alguns materiais e com eles, deveriam elaborar uma situação experimental e nela, verificar se existia ou não a conservação da quantidade de movimento do sistema.

Para fazer esta verificação, os alunos tiveram que elaborar um procedimento para testar a hipótese da conservação da quantidade de movimento, fazer as medidas necessárias e chegar a uma conclusão.

A nossa pesquisa procurou determinar se esta atividade proporciona aos alunos a oportunidade de penetrar no universo das ciências, ou seja, se ele leva à enculturação científica. Para tanto, buscamos indicadores, nas falas dos alunos, através das gravações das aulas, desta enculturação. Buscamos, também, indicadores de envolvimento com a atividade. Analisamos, além disso, a postura do professor, durante o experimento e na discussão em grupo.

Esta pesquisa se insere no contexto da enculturação científica, baseada nos trabalhos de Gil Pérez, Carvalho, Jimenez, Driver e Lawson, adaptados a uma realidade vivida em muitas de nossas escolas, ou seja, uma quantidade muito grande de conteúdos a serem trabalhados, poucos recursos e principalmente pouco tempo.

Palavras chave: 1. Laboratório aberto. 2. Enculturação científica. 3. Alfabetização científica. 4. Atividades experimentais. 


\section{ABSTRACT}

BIASOTO, J.E. The Thinking In Action Of The Students In Resolution of a Physics' Experimental Problem 2010 Dissertation (Master's Degree) - Institute of Physics e Education School - USP

In our research we have analyzed an experimental didactic activity in which the students received some materials for the elaboration of an experimental situation so that they should verify whether there was the conservation of linear momentum of a system.

In order to have this verification, the students were supposed to elaborate the procedure to test the hypothesis of conservation of momentum, get the necessary measures and come to a conclusion.

Our research has tried to determine if this activity offered the students an opportunity to enter the Science world, that is, if it took them into scientific enculturation. With this objective in mind, through the recording of our classes, we searched for indicators in the students' speeches that showed this enculturation. We also searched for indicators that showed commitment to the activity. Besides, we analyzed the teacher's posture not only during the experiment, but also during the group discussion.

This research is set in a scientific enculturation context, based on Gil Pérez's, Carvalho's, Jimenez's, Driver's and Lawson's papers, and adapted to the reality of many of our schools which have a lot of content to deal with, few resources and mainly little time.

Key-words: 1. Open laboratory. 2. Scientific enculturation.

3. Scientific literacy.

4. Experimental activities. 


\section{ÍNDICE}

Resumo

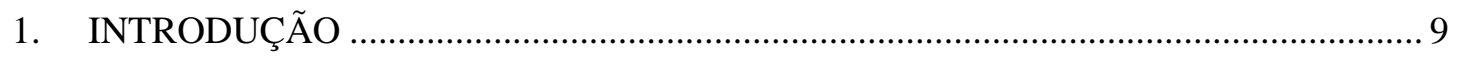

2. AS ATIVIDADES EXPERIMENTAIS NA SALA DE AULA …................................ 13

2.1 Críticas Às Aulas Tradicionais Na Área De Ciências .................................................. 13

2.2 Os Diversos Focos De Uma Atividade Experimental ................................................. 18

2.3 Propostas De Atividades Experimentais Que Levem À Enculturação Científica ......... 22

2.4 Habilidades A Serem Desenvolvidas Pelos Alunos Num Contexto De Enculturação

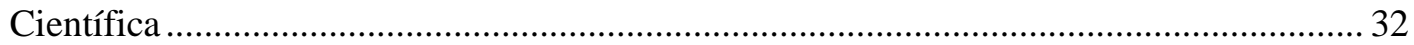

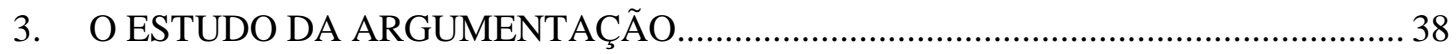

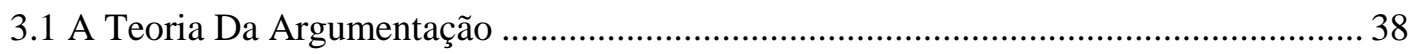

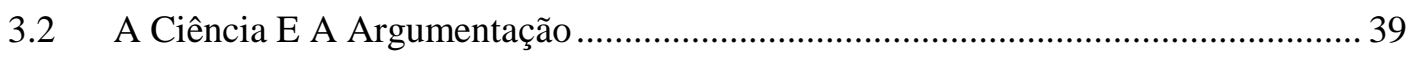

3.2.1 O Raciocínio Hipotético-Dedutivo.......................................................................... 40

3.3 A Argumentação E O Ensino de Ciências........................................................................ 42

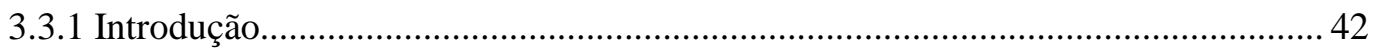

3.3.2 A Argumentação Dos Alunos Durante Atividades Experimentais ......................... 46

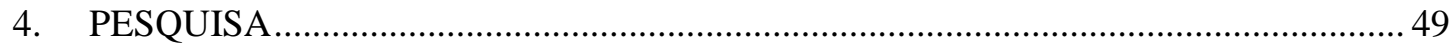

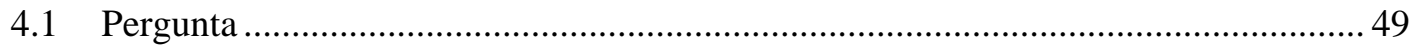

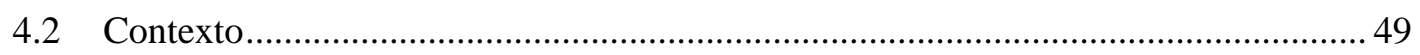

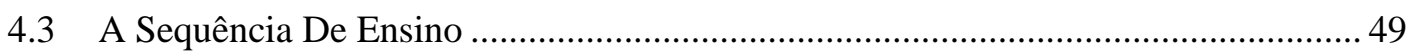

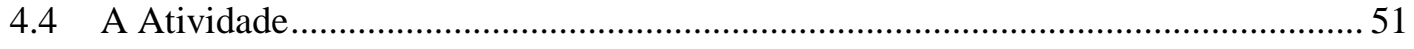

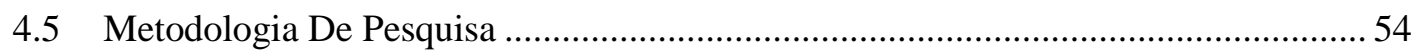

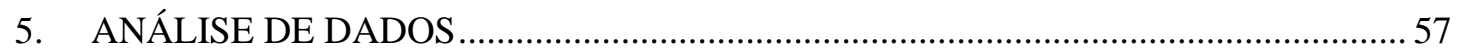

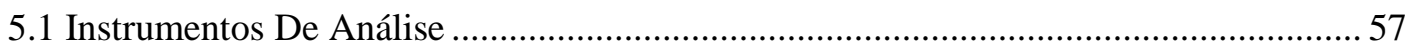

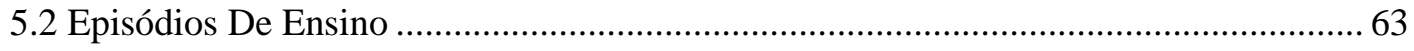

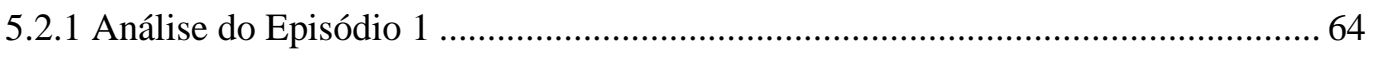

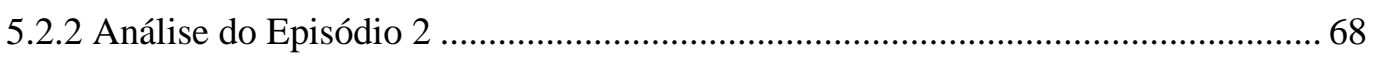

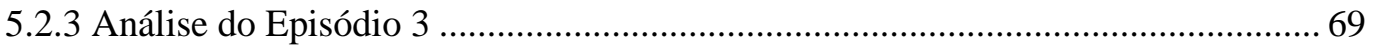

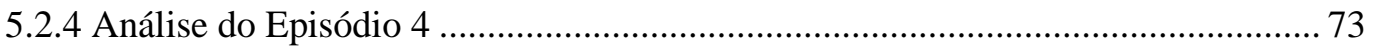


5.2.5Análise do Episódio 5

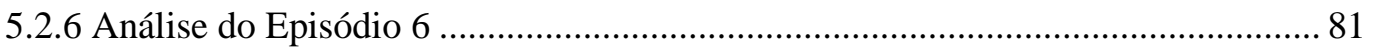

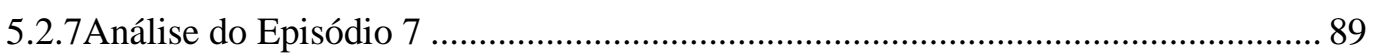

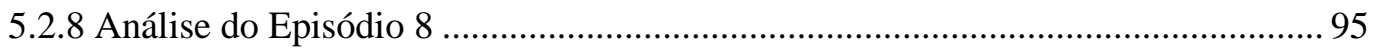

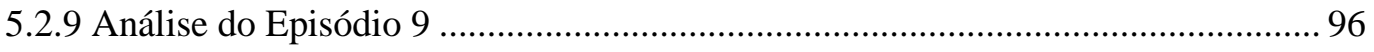

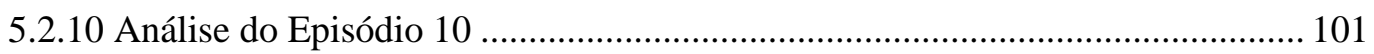

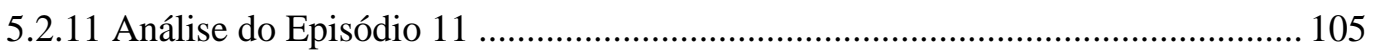

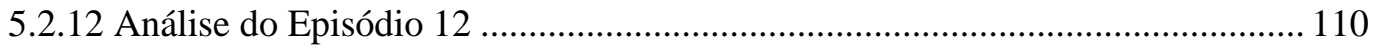

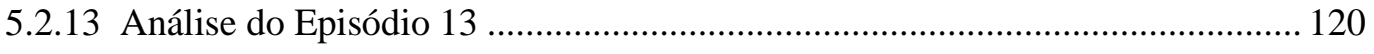

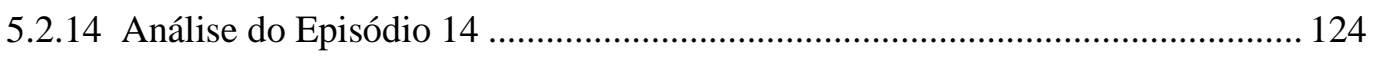

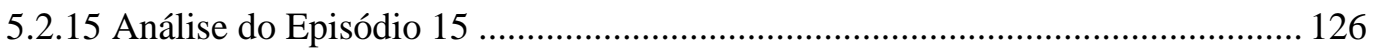

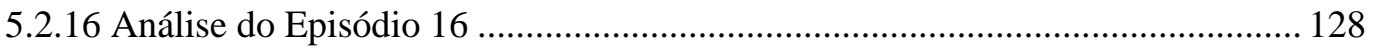

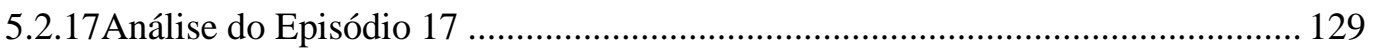

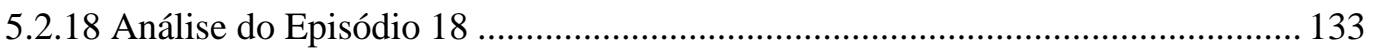

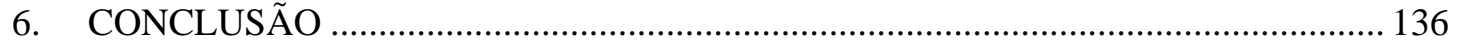

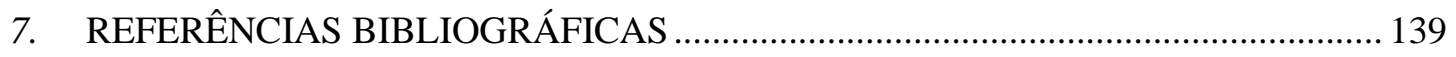

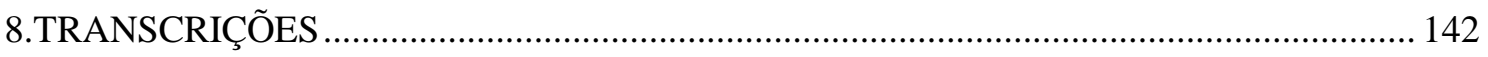




\section{INTRODUÇÃO}

Observando o panorama atual do ensino de Física no Brasil, o que vemos não é muito animador: uma preocupação excessiva com a memorização e aplicação de fórmulas, as quais, normalmente, não fazem o menor sentido, um descolamento dos conceitos ensinados com a realidade, a falta de interesse dos professores e alunos com as atividades experimentais, entre outros males que afligem em maior ou menor grau boa parte das escolas públicas e particulares no país.

No que se refere às atividades experimentais, o que observamos é que elas são utilizadas apenas como demonstrações de fenômenos, transformadas em meras curiosidades que procuram apenas motivar os alunos para o que realmente "interessa", do ponto de vista da maior parte da comunidade escolar (professores, diretores, coordenadores, pais, vestibulares, e consequentemente, alunos), que é a resolução algorítmica e automática de alguns exercícios pré-determinados. Nas vezes em que o laboratório didático é usado de maneira mais constante, o que nós observamos é a predominância de roteiros fechados e pré-determinados, os quais permitem que os alunos aprendam a manipular instrumentos, a fazer medições, mas que, quase nunca favorecem a elaboração e o teste de hipóteses, a conclusão, discussão e reelaboração de procedimentos experimentais por parte dos alunos.

Por outro lado, as PCNs, e muitas pesquisas na área de ensino de Física (Gil \& Castro, 2006; Driver et al., 2000; Carvalho, 2007) enfatizam a importância de colocar os alunos em contato com o universo das ciências, do qual fazem parte a elaboração e teste de hipóteses, a argumentação entre os pares, a tomada de decisões, durante uma investigação cientifica, e chegar a conclusões próprias do estudante ou do grupo que seja o resultado da própria investigação e não de respostas pré-determinadas.

Ao mesmo tempo, observamos um apoio teórico destes princípios por parte da mesma comunidade escolar citada anteriormente. Parece que todos querem um ensino de Física mais contextualizado, dinâmico que realmente permita aos jovens a apropriação de conceitos, o entendimento de fenômenos e a introdução dos estudantes neste universo próprio dos cientistas. 
Entretanto, o que acontece, muitas vezes, quando estes princípios são aplicados no dia a dia escolar? Atividades inovadoras que a principio são pedidas pela comunidade escolar, quando aplicadas, são questionadas, rejeitadas e o trabalho do professor (que não foi pouco) desvalorizado.

Por que isto acontece? Um levantamento da literatura com exemplos práticos de aplicações de atividades que têm como objetivo a enculturação cientifica dos estudantes mostra que estas atividades demandam, muitas vezes, um número de aulas incompatível com os currículos de Física atuais, nos quais há pouco tempo para se estudar uma enorme quantidade de temas, conceitos, fórmulas, etc.

Parece então que para que houvesse realmente um processo de ensino aprendizagem que proporcionasse aos alunos uma verdadeira enculturação cientifica, deveria antes, ocorrer uma revolução na Educação como um todo, ou estes objetivos ficariam restritos a poucos professores ou a poucas escolas que se abstivessem de apresentar todo o conteúdo do ensino médio ou a preparar os seus alunos para os vestibulares.

Paralelamente, alguns autores, como Laburu et al (2003) criticam a visão "a la Gil" (Laburu et al, 2003) das atividades didáticas experimentais. Para eles, estas atividades apresentam dificuldades conceituais e experimentais acima da capacidade dos alunos, o que os inviabiliza.

Neste ponto, surgem questões que afligem muitos professores. Será que é possível, no nosso contexto atual do ensino de Física, desenvolver habilidade de testar hipótese, através de experimentos, nos nossos alunos? Será que é possível um processo de ensino-aprendizagem que, ao mesmo tempo, inclua os estudantes no universo das ciências e os treine para o vestibular.

Será que é possível o desenvolvimento de atividades didáticas experimentais, as quais façam com que os alunos aprendam a resolver problemas experimentais utilizando um número reduzido de aulas?

A atividade didática experimental aplicada nas aulas analisadas nesta pesquisa procura ser uma possível resposta a estas perguntas. 
O seu objetivo é fazer com que os alunos criem uma situação, usando determinados materiais e com eles, verificar a hipótese de que a quantidade de movimento do sistema se conserva. Para tanto, os alunos devem elaborar um procedimento e fazer as medidas e cálculos necessários para testar a hipótese inicial.

Depois, os resultados são compartilhados com a classe.

Assim, o nosso problema de pesquisa é observar e analisar como os alunos resolvem este problema experimental, ou seja, como os conceitos aprendidos são mobilizados para este trabalho, como é desenvolvida a sua habilidade em resolver um problema experimental, como é a sua estrutura de pensamentos, porque fases ele passa durante o trabalho, como eles expõem este trabalho e qual é o papel do professor em tudo isso.

Esta dissertação está estruturada da seguinte forma: no capítulo dois, foi feita uma revisão bibliográfica dos trabalhos relacionados a atividades experimentais, especialmente os que trabalham no contexto da enculturação científica. Deu-se ênfase aos trabalhos que levantam parâmetros a serem seguidos por atividades didáticas de investigação dirigida, com o objetivo principal sendo o levantamento e o teste de hipóteses por parte dos alunos, permitindo aos estudantes estabelecer o seu próprio desenho experimental. Como contraponto, é mostrado o trabalho de Laburu, defendendo a multiplicidade de objetivos do trabalho experimental em sala de aula e chamando a atenção para as dificuldades práticas do desenvolvimento das aulas de investigação dirigida. A atividade analisada na nossa pesquisa se coloca entre estas duas concepções, pois ela tem como objetivo principal fazer com que os estudantes descrevam um procedimento para testar uma hipótese.

No capítulo três, foi feita uma revisão bibliográfica das pesquisas relacionadas à análise da argumentação dos estudantes, destacando-se os trabalhos de Toulmin, Driver et al. e Lawson, pois a atividade didática desenvolvida para a nossa pesquisa tem também como objetivo permitir e desenvolver a argumentação dos alunos.

No capítulo quatro, contextualizamos a nossa pesquisa, mostrando alguns aspectos da escola onde foi aplicada a atividade e do professor que a aplicou. Neste capítulo, também, detalhamos a atividade analisada bem como a metodologia da pesquisa e os instrumentos de análise. 
No capítulo cinco, analisamos os dados colhidos durante a atividade segundo os seguintes aspectos: a procura de indicadores de capacidade de resolver um problema experimental por parte dos alunos, a procura de indicadores de envolvimento dos alunos com a atividade, as ações do professor, a análise da argumentação dos alunos buscando em suas falas a estrutura de pensamento e a análise do entendimento dos conceitos físicos envolvidos na atividade.

No capítulo seis apresentamos as conclusões a que chegamos nesta pesquisa. 


\section{AS ATIVIDADES EXPERIMENTAIS NA SALA DE AULA}

\subsection{Críticas Às Aulas Tradicionais Na Área De Ciências}

Há uma aceitação cada vez maior das propostas educacionais que dão aos estudantes uma participação crescente na construção e reconstrução de conhecimentos a serem trabalhados em sala de aula. (Gil et al. 1999).

Isto não valida a proposta de pensar nos alunos como cientistas na fronteira do conhecimento, como pesquisadores autônomos que sob a orientação do professor aprendem por "descobrimento". Mais efetiva é a imagem de "investigadores novatos”, os quais, divididos em equipes cooperativas, trabalham situações problematizadas, interagindo com os colegas, o professor e o livro texto (uma metáfora da comunidade científica). (Gil et al. 1999)

Para tanto, faz-se necessária a superação de visões deformadas e simplificações do trabalho científico. O conceito que os professores e alunos têm do trabalho do cientista como a soma de alguma experiência e bom senso, bem como as omissões, a falta de contextualização e problematização na sala de aula, levam ao ensino de ciências que vemos hoje em dia. (Gil et al. 1999)

Uma concepção de ensino que aproxime a sala de aula do trabalho real do pesquisador deve integrar a teoria, a prática e a resolução de problemas.

É muito comum, numa sala de aula, o professor ao explicar um fenômeno ou um conceito, partir de situações idealizadas, distante das condições realmente existentes na natureza ou no cotidiano. Qual é o professor de física que nunca proferiu a expressão "despreze o atrito e a resistência do ar"? Acontece que o que os alunos mais observam no dia a dia é a influência do atrito e da resistência do ar no movimento de um corpo. Esta postura gera no aluno a sensação de que o que ele aprende na escola vale só na escola e não na vida real, o que gera no aluno uma grande frustração quando este tenta conciliar o que é aprendido nas aulas de ciências e em particular na física com o que ele observa no seu dia a dia. 
Rowe e Holland (1990) apud Lunetta et al.(2007) descrevem esta frustração na fala de um aluno de física que associa ao discurso científico a um jogo, que só pode ser jogado pelos cientistas, pois eles dizem que se um corpo é lançado num plano horizontal com certa velocidade, esta se manterá constante, desde que não haja atrito, resistência do ar ou nenhuma força contrária. Entretanto, qualquer pessoa pode observar que depois que soltamos um corpo, na horizontal, este começa a parar. Os professores, como representantes do mundo acadêmico dizem que isto acontece devido ao atrito e que se nós o retirarmos, o corpo não pararia. O aluno ouve aquilo e se frustra, pois ele não consegue observar esta condição (ausência de atrito) no seu dia a dia e, portanto, precisa acreditar no que o seu professor (representante da comunidade científica) diz sem provas o que contradiz o que este próprio professor diz, ou seja, que as ciências são baseadas em provas experimentais ou empíricas.

Explicações e textos nos quais aparecem situações idealizadas (ausência de atrito ou resistência do ar) não favorecem o aprendizado da parte do aluno, pois estas situações não fazem parte do cotidiano deles (Mathews, 1994 apud Lunetta et al., 2007). O laboratório didático pode ser um ambiente que favoreça esta aprendizagem se as condições nas quais forem realizados os experimentos forem mais próximas das encontradas no cotidiano dos alunos. Assim, partindo de uma situação concreta, real, pode-se discutir a possibilidade de se desprezar algumas variáveis (atrito, por exemplo), em cada caso tornando a ausência de atrito ou a sua irrelevância para o problema a ser resolvido, uma hipótese a ser considerada e que deve ser testada.

Desta maneira, o aluno percebe quais são as variáveis relevantes em cada situação e quais podem ser desconsideradas.

Agora, uma conclusão (por exemplo, que o atrito possa ser desprezado numa determinada situação), não é uma observação absoluta ou livre de contradições. Aliás, as contradições, discussões e disputa, fazem parte da natureza do trabalho cientifico e devem fazer parte do trabalho realizado em sala de aula (Mathews, 1994 apud Lunetta et al, 2007).

Esta visão do trabalho cientifico se contrapõe à visão que muitos alunos e professores têm deste mesmo trabalho. 
Mattews (1994) apud Lunetta et al.(2007) aponta alguns elementos presentes nesta visão idealizada do trabalho dos cientistas que dificultam a apropriação por parte dos estudantes de uma visão mais realista da natureza das ciências:

1- Os processos na natureza trazem implícitos, dentro de si, um estado final. É como se todo processo natural fosse um filme, cujo final já é conhecido. Esta visão é acentuada pela tendência dos professores de procurarem sempre valorizar o resultado final, em detrimento de processo. Se, no trabalho de laboratório, os alunos devem necessariamente chegar a um valor de uma constante já conhecida, esta visão se acentua, pois independentemente do processo, o final já está presente, podendo apenas os alunos estar certos ou errados.

2- O conhecimento é fixo e imutável.

Um ensino que não promove o debate, a argumentação e o levantamento e teste de hipóteses, apenas reforça estas idéias, tornando a figura do professor algo próximo ao de um mensageiro da verdade a qual os alunos apenas se submetem e observam.

3- O conhecimento cientifico é produzido apenas através da observação da natureza.

Esta visão é carregada da percepção de que qualquer pessoa ao se deparar com um fenômeno qualquer deveria chegar sempre à mesma conclusão. Se ela não chegou, é porque ela é que está errada e não porque existem visões diferentes do mesmo fenômeno. Novamente, um ensino de ciências que não possibilita o debate e a argumentação, apenas reforça esta visão.

4- Os conhecimentos científicos são válidos apenas pelo sucesso de suas provisões.

Um exemplo desta visão é o fato de muitos professores afirmarem que o modelo Geocêntrico foi substituído pelo Heliocêntrico porque este fornecia previsões mais exatas do movimento dos planetas do que o anterior, o que não é verdade, especialmente na sua gênese. De novo, esta visão exclui o debate, o contraditório, a luta entre duas visões de mundo diferentes (Lunetta et al., 2007). Estas afirmações fazem parte, consciente ou inconscientemente do processo de ensino-aprendizagem de grande parte de professores e estudantes. 
Um processo de ensino aprendizagem baseado apenas na exposição dos conceitos e em procedimentos experimentais fechados que visam apenas à confirmação de variáveis já conhecidas têm implícitas estas afirmações como verdadeiras.

Afinal, para que fomentar debates "inúteis" se o conhecimento já está estabelecido, fixo e não vai mudar?

Vários pesquisadores, ocupados em vencer estas visões deformadas do trabalho cientifico, têm colocada a sua atenção no desenvolvimento de atividades que favoreçam a argumentação e o debate entre os estudantes.

Lunetta et al. (2007), analisando diversos autores que pesquisam a postura dos alunos durante uma atividade experimental, chegam à conclusão que eles têm grande preocupação com a coleta e a interpretação de dados, no sentido de que estes dados devem ser interpretados para se chegar à "resposta correta", confirmando a conclusão a que chegou Mattews (1994) apud Lunetta et al. (2007), ou seja, que, para os alunos, existe uma única "resposta certa" em uma atividade experimental, à qual deve ser confirmada pela experimentação. Quando isto não acontece, foram os alunos que erraram em algum procedimento, e estes pouco cogitam a possibilidade de que seu procedimento esteja correto e que deve haver alguma outra variável não considerada que fez com que o resultado esperado não fosse alcançado. Por outro lado, Duschl (2002) apud Lunetta et al. (2007), afirma que os estudantes passam a compreender a natureza do trabalho cientifico quando eles empreendem investigações experimentais nas quais têm liberdade de argumentar e debater a respeito de boas evidências contraditórias no mesmo fenômeno e podem escolher por uma delas.

Schwartz e Ledermen (2002) disseram que os estudantes aprendem sobre a natureza do trabalho cientifico quando são promovidas, em sala de aula, reflexões sobre as atividades práticas e estas reflexões são o foco de trabalho do professor e não apenas um pequeno adendo da aula. Segundo estes autores, estas reflexões devem ser colocadas no centro da atenção do trabalho dos estudantes.

Poucas palavras podem significar tanto ou ter o seu conteúdo esvaziado como a palavra "construção" ou a palavra "construtivismo", muitas vezes pensada dogmaticamente, tornando-se exatamente aquilo que é criticado, uma "receita de bolo", pois para muitos, para que haja a construção do conhecimento basta que se percebam os 
conhecimentos prévios dos alunos, cria-se aí um conflito cognitivo, o aluno se desequilibra, para depois subir de patamar, equilibrando-se novamente num nível superior. Não se está aqui negando estas afirmações, mas sim analisando como uma boa idéia, quando tomada sem reflexão, acriticamente, não resolve o problema do ensinoaprendizagem. Muitas vezes, o professor faz o levantamento das idéias dos alunos, para depois simplesmente contestá-las, levando o aluno a um conflito de opiniões, entre o seu conhecimento e o do professor ou entre o senso comum e o conhecimento científico o que não muda o aluno. (Gil et al. 1999)

Agora, se ao invés de simplesmente o professor perguntar aos alunos o que eles acham sobre determinado tema, propor a eles um problema a ser resolvido, os conhecimentos prévios são mobilizados para esta resolução através da proposição e teste de hipóteses as quais ao encontrarem seus limites, podem levar o aprendiz a evoluir para uma concepção mais próxima à aceita pela ciência formal, havendo então um crescimento conceitual gerado pelo desejo de resolução de um problema interessante para o aluno (Gil et al. 1999).

Assim, além da mudança conceitual, há uma mudança metodológica e atitudinal, durante a aprendizagem em ciências (Gil et al. 1999).

Muitos alunos e muitos professores vêm as ciências da mesma forma que estas são mostradas nas histórias em quadrinhos, no cinema e na televisão: ela é produzida por um herói solitário, um cientista, um "gênio" acima do bem e do mal (Gil et al., 2001), sem contato com a sociedade e seus problemas ambientais ou energéticos. Ele busca através de experimentos, ler o "livro da natureza" e estes experimentos o conduzirão à "verdade", à “descoberta", à revelação pura de algo que estava escondido aos comuns dos mortais. Segundo Gil et al. (2001), esta forma de ver o trabalho científico faz com que, na sala de aula, as atividades experimentais estejam muito pouco presentes, pois apenas um "gênio" pode elaborar um experimento e através dele, chegar à "verdade" e depois que este "gênio" conseguiu fazer esta descoberta, lendo o "livro da natureza", todos os que vierem depois dele, necessariamente, chegarão aos mesmos resultados. Esta visão empírico-indutivista e ateórica é tão arraigada que a grande maioria nem percebe que compartilha dela (Gil et al., 2001). Uma conseqüência do empirismo indutivista é a grande importância que os professores dizem ter as atividades experimentais (importância esta que não se traduz na prática, já que o ensino, na maioria 
das vezes é baseado apenas na transmissão de conteúdos encontrados num livro texto). Cria-se assim o mito da experiência como condutora para verdade, o qual permanece como tal, já que a prática pedagógica, devido aos mais variados motivos não é embasada nos trabalhos experimentais.

Assim, quando acontece de a prática pedagógica utilizar-se das atividades experimentais, surge outra deformação, a crença num método rígido, algorítmico e infalível, o método científico, o qual se for seguido à risca, levará o pesquisador a grandes descobertas. Esta deformação transforma as práticas experimentais numa seqüência de etapas que devem ser seguidas à risca (Gil et al., 2001), como uma "receita de bolo", porém uma receita entronizada no panteão dos sábios, o "método científico".

Para que estes passos sejam programados com precisão, faz-se necessário que os conhecimentos transmitidos sejam sobejamente conhecidos, despidos de sua contextualização histórica e de problematização. Reforça-se assim, a visão do trabalho experimental como um algoritmo que deve ser seguido à risca para que se encontre o que se deseja (e que já se sabia de antemão que iria ser encontrado).

Estes algoritmos trabalham sempre com pequenas partes, com unidades mínimas do saber, pois há, no ensino, a preponderância de uma visão puramente analítica do conhecimento, não se levando em conta as inter-relações entre áreas distintas e as grandes unificações.

Quando se despe um conhecimento dos processos que o construíram, das controvérsias e do seu contexto social e histórico, cai-se na simplificação da visão linear (Gil et al., 2001) da sua evolução. Parece que simplesmente "uma coisa leva à outra", sem crises ou rupturas, fundamentais neste processo (Khum, 1993).

\subsection{Os Diversos Focos De Uma Atividade Experimental}

O estudo das práticas experimentais no ensino de Física não é novo. Desde o tempo das corridas armamentista e espacial, durante a guerra fria, vêm-se estudando como melhorar o aprendizado dos alunos nas áreas de ciências e sempre o desenvolvimento das práticas experimentais é colocado em primeiro plano. O conceito clássico de laboratório didático vem desde o século XIX e consiste em aprender experimentos nos quais estudantes interagem com materiais ou fontes secundárias de 
dados para observar e entender o mundo natural (Lunetta et al., 2007). Através destes experimentos, os professores têm a oportunidade única em ciência de ajudar estudantes a se maravilhar a respeito do mundo natural, experimentando e observando diferentes fenômenos e objetos, explorando idéias e conceitos no entendimento científico (Lunetta et al, 2007). A partir da década de 60, baseado nas teorias de aprendizagem de Piaget, Brune e Gagne, os currículos de ciências inicialmente os americanos e britânicos, passaram a dar ênfase a atividades e projetos que permitissem aos estudantes desenvolver e testar hipóteses e teorias e praticar a forma de trabalhos dos cientistas. Para tanto, as atividades didáticas experimentais têm deixado de ser apenas a execução de roteiros pré-estabelecidos com resultados previamente conhecidos para se tornarem investigações conduzidas pelo professor nas quais os estudantes explorem problemas em aberto e articulem, eles mesmos, sua resolução (Lunetta et al., 2007). O foco dos pesquisadores têm sido desenvolver uma educação voltada para a participação plena dos indivíduos, que devem estar capacitados a compreender os avanços tecnológicos atuais e a atuar de modo fundamentado, consciente e responsável diante de suas possibilidades de interferência nos grupos sociais em que convivem (Thomaz, M. F. 2000).

Lunetta et al (2007) mostram que as atividades didáticas experimentais aumentam o interesse dos alunos pelas ciências, principalmente se eles se envolvem diretamente na experimentação, ou seja, quando o aluno é protagonista da atividade, o seu interesse pelas ciências e o seu envolvimento crescem.

Desse modo, é possível constatar que o uso da experimentação como estratégia de ensino de Física tem sido alvo de inúmeras pesquisas nos últimos anos, havendo extensa bibliografia em que diferentes autores analisam as vantagens de se incorporar atividades experimentais. Entretanto, a forma e os meios com que a experimentação é empregada diferem significativamente nas propostas investigadas, de modo que os trabalhos de diferentes autores apontam para diversas tendências no uso desta estratégia (Araújo e Abib, 2003).

Segundo Araújo e Abib (2003), as pesquisas que têm como foco as práticas experimentais podem ser classificadas pelos seguintes parâmetros:

a) Ênfase Matemática - qualitativos ou quantitativos. 
b) Grau de Direcionamento - experimentos de verificação, demonstração ou investigação e o seu grau de abertura (aberto ou fechado).

c) Uso de Novas Tecnologias - muitas pesquisas procuram verificar o uso de novas tecnologias, incluindo aí, simulações, no laboratório didático.

d) Cotidiano - pesquisas sobre a utilização de fenômenos do dia a dia nas práticas experimentais.

e) Montagem de Equipamentos - muitos pesquisadores têm como foco a montagem de novos equipamentos e aparelhos de laboratório.

Alguns pesquisadores procuram analisar as aulas de prática experimental na perspectiva da enculturação científica (Carvalho 2007, Gil 2001) e dentro desta perspectiva, faz-se importante a análise da argumentação dos alunos nestas aulas (Driver et al. 2000, Jiménez et al. 2000, Capecchi e Carvalho, 2000).

Nesta seção, vamos analisar as práticas experimentais segundo a ênfase matemática (atividades qualitativas ou quantitativas) e o grau de direcionamento (atividades abertas ou fechadas). Estas práticas, sob a perspectiva da enculturação científica e a argumentação dos estudantes serão trabalhadas em outras seções.

\section{Ênfase Matemática:}

- Atividades Qualitativas

Nas atividades analisadas nestes trabalhos, a ênfase está nos aspectos qualitativos, no desenvolvimento de conceitos e na metodologia, sendo que os aspectos quantitativos e formais, ou são deixados de lado ou têm uma importância marginal (Araújo, Abib, 2003). Muitas vezes, estas atividades estão relacionadas com o uso de atividades abertas, ou laboratório não estruturado.

Este tipo de atividade pode ter como objetivo, mapear os conceitos espontâneos dos alunos, gerar uma mudança conceitual, fazer com que os alunos testem uma determinada hipótese ou fazer com que os alunos resolvam certo problema experimental.

Estas atividades podem ter caráter investigativo, onde há uma investigação orientada, ou podem ser de demonstração, realizadas pelo professor. 
- Atividades Quantitativas

Neste tipo de atividade, a ênfase pode estar na comparação entre modelos previstos e resultados experimentais, a verificação de leis físicas e os seus limites de validade, bem como no trabalho estatístico dos dados focando a propagação de erros e nos desvios e incertezas. Este tipo de atividade pode também tornar mais concretos os conceitos abordados em aula. Através deste tipo de atividade também se obtém uma maior familiaridade com os instrumentos de medida e equipamentos (Araújo e Abib, 2003).

Normalmente, este tipo de experimento é fechado, limitando as possibilidades de argumentação e de levantamento e teste de hipóteses por parte dos alunos, porém, é possível a execução de atividades abertas ou a resolução de problemas abertos quantitativos, como o proposto por Chernikoff et al. (1999), para um estudo da lei de Boyle na qual os estudantes podem levantar e testar hipóteses.

\section{Grau de direcionamento}

Uma atividade experimental pode ser mais ou menos direcionada pelo professor, dependendo dos objetivos didáticos procurados. Nesta pesquisa, vamos classificar as atividades, segundo o grau de direcionamento, em atividades fechadas, como aquelas mais centradas no professor ou com roteiros fixos e em abertas, como sendo as que dão um grau de liberdade maior aos alunos.

- Atividades fechadas

A característica deste tipo de atividade é a existência de um roteiro fixo, prédeterminado.

O objetivo aqui pode ser a ilustração de um determinado fenômeno por uma demonstração realizada pelo professor. Este tipo de apresentação é muito utilizado, em aulas predominantemente expositivas, pois demanda pouco tempo, podendo acontecer no início de uma aula, para despertar o interesse dos alunos ou no final, como fechamento de um tema (Araújo e Abib, 2003).

Outro objetivo perseguido por atividades fechadas é a verificação experimental de determinadas leis ou a medida de constantes físicas. Nestas atividades, os alunos aprendem a manusear materiais e instrumentos, a fazer medidas, analisar gráficos e 
observam quantitativamente alguns fenômenos. A análise estatística e o tratamento de erros também é uma característica destas atividades.

- Atividades abertas

Estas atividades se caracterizam por uma maior flexibilidade procedimental e metodológica, permitindo uma participação maior dos alunos, não só na execução da atividade, colhendo dados, mas também e principalmente levantando e testando hipóteses.

Uma atividade de demonstração pode ser considerada aberta se ela possibilitar a participação dos alunos, levantando e testando hipóteses, fazendo com que haja uma discussão conceitual durante a aula (Araújo e Abib, 2003).

Normalmente, as atividades de verificação ou de aplicação são fechadas, porém se houver a possibilidade, nestas atividades, de discussão de conceitos ou procedimentos, para testar a validade ou os limites de validade de uma lei ou aplicar os conceitos construídos na resolução de um problema experimental, este tipo de atividade pode se tornar aberta.

A resolução de problemas experimentais e as investigações orientadas são atividades típicas de um laboratório aberto ou não estruturado. Nestas atividades, normalmente há o levantamento e/ou o teste de hipóteses e muitas vezes a elaboração ou reelaboração dos procedimentos experimentais por parte dos alunos (Gil et al. 1999).

\subsection{Propostas De Atividades Experimentais Que Levem À Enculturação Científica}

Diversos trabalhos nacionais e estrangeiros, ultimamente têm colocado o foco de sua atenção nas intervenções dos alunos e do professor durante uma atividade experimental, para que os alunos consigam entrar e viver no universo das ciências ou em outras palavras, para que haja enculturação científica. Há muito tempo, a Pesquisa em Ensino de Ciências tem produzido conhecimento sobre o que é relevante para a aprendizagem dos alunos, tanto em conteúdo conceitual, mas principalmente sobre o processo de produção do conhecimento científico.

Aqui, serão apresentadas algumas destes trabalhos. 
A análise destes trabalhos mostra que as conclusões a que os autores chegam são muito parecidas, ou seja, diversos autores de origens diferentes dizem a mesma coisa, de formas diferentes, chegando a resultados similares.

Driver et al. (2000) propõem que a aprendizagem em ciências pode ser comparada à aprendizagem de uma língua estrangeira, na qual não basta aprender o nome das coisas, mas sim, é necessário que o estudante mergulhe numa nova cultura, compreendendo suas normas, valores, linguagem e processos

"Esta abordagem do ensino de Física, pensado como uma verdadeira enculturação, uma enculturação científica, permite ao professor compreender as dificuldades dos alunos em assimilarem os novos conceitos apresentados, pois ele se sente como que estrangeiro em outro país, cuja língua e costumes lhe são completamente estranhos (Capecchi e Carvalho 2000).'

Neste sentido, as aulas devem ser planejadas para aumentar a participação dos alunos, tornando-os intelectualmente ativos, capazes de fazer escolhas e tomar decisões. Para isso, as atividades investigativas e o Laboratório Aberto podem dar uma grande contribuição.

Gunstone (1990) apud Lunetta et al. (2007) ressalta a importância dos estudantes terem a oportunidade de levarem hipóteses e elaborar atividades experimentais que gerem uma investigação que vá testar estas hipóteses.

Duschl e Osborne (2002) ressaltam a importância das atividades didáticas experimentais fornecerem aos estudantes a oportunidade de discutir idéias entre eles e tomarem decisões a respeito dos rumos da atividade. Quando o professor coloca atenção nestas discussões e decisões, ele pode perceber o ponto em que os alunos estão em relação a um determinado conceito ou procedimento, através de uma pergunta, uma observação, uma explicação, levar os alunos a atingir outro patamar de entendimento.

Lunetta et al. (2007) dizem que a simples manipulação de instrumentos num roteiro fechado não leva os estudantes a desenvolver as habilidades típicas do "fazer ciência" (Jiménez, 2000). É necessário que as atividades didáticas experimentais 
encorajem os estudantes a articular e discutir idéias e perceber as discrepâncias entre elas, transformando a sala de aula numa comunidade cientifica.

Lunetta et al. (2007) propõem um ensino de ciências com foco nas atividades didáticas experimentais, as quais devem perseguir os seguintes objetivos:

1 - Desenvolver conhecimento conceitual.

2 - Desenvolver a habilidade na resolução de problemas experimentais.

3 - Desenvolver a argumentação baseada em dados experimentais.

4 - Conhecer como os cientistas trabalham.

5 - Desenvolver o interesse e a motivação dos estudantes.

6 - Desenvolver o entendimento dos métodos da pesquisa cientifica.

7 - Desenvolver o entendimento da natureza das ciências.

Lunetta et al. (2007), analisando os trabalhos de diversos autores ressaltam a importância do laboratório didático se transforma numa comunidade de aprendizagem cooperativa.

Nesta comunidade, o professor deve conduzir a atividade no sentido de promover a interação dos estudantes entre si, para que haja efetivamente um crescimento conceitual e cognitivo.

O foco destas atividades, segundo os autores deve ser a reflexão do processo e a negociação entre os pares.

Lazarowitz e Karsentyl (1990) apud Lunetta et al. (2007) compararam as notas de Biologia de dois grupos de alunos, o primeiro que trabalhou em pequenos grupos cooperativos e outro que trabalhou individualmente. Ele percebeu que o grupo cooperativo obteve notas maiores que o grupo onde os alunos trabalhavam individualmente, sem cooperação.

Lunetta et al. (2007) ressaltam a importância do laboratório didático para desenvolver a integração entre professor e alunos e principalmente entre os alunos entre 
si, fazendo com que da interação entre um estudante e seus pares sob a condução do professor surgiu um crescimento cognitivo e conceitual.

Diversos autores (Land e Zembal-Saul 2003; Edelson et. al. (1999) apud Lunetta, 2007) têm procurado propor maneiras de tornar o laboratório didático numa comunidade colaborativa de aprendizagem. Estes autores procuram nestas atividades fazerem com que o seu foco seja reflexão do processo e a negociação entre os pares.

Land e Zembal-Saull (2003) estudam o uso do portfólio, um diário no qual os alunos colocariam seus apontamento e reflexões que aconteciam durante a investigação. Nestas reflexões estavam as negociações e articulações entre os alunos para se chegar à resolução de um problema e nestas negociações, apareciam os dados como base de uma argumentação, com suas justificações (Lunetta et al., 2007).

Borges et al. (2005) procuraram analisar os planos dos estudantes para resolver problemas práticos. Eles analisaram planejamentos que os estudantes elaboraram para identificar que fatores interferem em dois eventos diferentes e suas estratégias para testar como estes fatores interferem nestes eventos.

Eles trabalharam com os planos individuais apresentados por escrito por setenta e três alunos da terceira série do ensino médio. Os planos individuais foram agrupados em quatro categorias, de acordo com a sua qualidade. Buscou-se uma correlação entre a qualidade dos planos e o desempenho escolar dos autores.

O objeto de estudo dos autores é o pensamento em ação dos estudantes, ou seja, a mobilização do seu entendimento conceitual em física, bem como as habilidades adquiridas na coleta de dados experimentais para o planejamento de uma investigação científica. Os autores avaliam este conjunto pelo que eles chamam de "qualidade do planejamento", baseado em cinco parâmetros:

"1- As decisões do estudante sobre a seleção de variáveis a serem investigadas;

2- Seu entendimento da natureza das variáveis;

3- Distinção entre variáveis dependentes e independentes;

4- As decisões sobre as estratégias escolhidas para a obtenção de dados confiáveis;

5-Seu entendimento do que é evidência e de como a qualidade delas é afetada pelos dados obtidos."

(Borges et al.2005, pag 436). 
Para tanto, foram propostos dois problemas, os quais foram resolvidos pelos

alunos, inicialmente de forma individual. Depois os alunos foram divididos em grupos de quatro ou três integrantes e os planos individuais de resolução foram coletados e analisados pelo grupo o qual reelaborou um novo plano.

Os autores chegaram à conclusão que os fatores levantados pelos estudantes como relevantes para a resolução do problema apresentado estão mais ligados ao senso comum que ao desempenho deles em física, entretanto, a qualidade dos planos individuais propostos para testar as hipóteses levantadas por eles está sim fortemente ligada ao seu desempenho na disciplina.

A motivação dos estudantes durante uma atividade experimental foi estudada por Guridi e Islãs (2003) que compararam o desempenho dos alunos numa atividade tradicional fechada e na resolução de um problema experimental aberto, entendendo-se aqui como uma atividade fechada, aquela que não permite que o aluno siga outro caminho que não o escolhido pelo professor e atividade aberta seria aquela na qual o aluno tem alguma liberdade de movimento. Neste trabalho, também são estudadas as dificuldades dos professores e alunos em trabalhar com uma atividade experimental aberta.

Foram escolhidas duas atividades, uma sobre movimento e outra a cerca da lei de Faraday e foram escolhidos alguns critérios que nortearam a elaboração dos experimentos abertos:

1- Despertar a motivação dos estudantes.

2- Propor atividades que disparem as idéias prévias dos estudantes sobre o fenômeno e que permitam a eles emitir suas próprias hipóteses.

3- Deve haver a possibilidade de os estudantes testarem diferentes formas de experimentação.

4- Deve haver discussão nos grupos a respeito dos itens anteriores.

5- Os experimentos devem enfatizar aspectos qualitativos e não só quantitativos do fenômeno estudado. As medições devem fomentar a discussão a cerca do fenômeno e não serem a razão de ser do experimento. 
6- Se possível, deve haver discussões a respeito da história da ciência.

Os mesmos temas (movimento retilíneo e uniforme e lei de Faraday) foram desenvolvidos por dois outros grupos de forma fechada.

Os dados foram analisados a partir de entrevistas com os alunos.

Percebeu-se que quando as atividades foram fechadas, a expectativa dos alunos concentrou-se na comprovação de leis, os quais seguem rigorosamente o plano traçado sem tentar maneiras alternativas de trabalho. Os estudantes que seguiram um desenho mais aberto, por sua vez, estiveram altamente motivados durante todo o experimento, motivação manifestada através de perguntas e pela intenção de propor outras formas de realização do trabalho. Percebeu-se também, que através das atividades abertas, houve menor confusão conceitual e um maior entendimento das variáveis centrais do problema. $\mathrm{O}$ uso das atividades abertas favorece a contextualização, abrindo possibilidades maiores dos estudantes colocarem à prova suas idéias e sua análise crítica. Os autores consideram que houve uma boa aproximação da “ciência escolar" com a ciência dos cientistas.

Alguns autores estudaram a influência dos materiais didáticos no processo de enculturação científica. Os materiais utilizados no laboratório devem ser apropriados para a finalidade da atividade. Se os materiais não são familiares aos estudantes, às vezes, o foco da atenção deles passa a ser os materiais e não os conceitos a serem estudados (Olson, 2004 apud Lunetta et al., 2007). Assim, o uso de equipamentos sofisticados, softwares inovadores ou outras inovações tecnológicas às quais não fazem parte do cotidiano dos alunos, se por um lado atraem a atenção dos alunos, promovendo o seu interesse pela atividade, por outro lado, se não forem muito bem balanceados, podem fazer com que os estudantes percam o foco do que seria realmente relevante na investigação.

As atividades experimentais nas quais os alunos elaboram e reelaboram procedimentos experimentais, fornecem oportunidades aos estudantes de desenvolver as habilidades, de tomar decisões à cerca dos rumos da investigação. Esta habilidade aproxima os estudantes do universo típico do trabalho dos cientistas (Lunetta et al., 2007). 
Pizzini et al. (1989) estudaram as fases que devem constituir uma atividade didática experimental e defendem a idéia de que elas devem ter 4 fases: pesquisar, resolver, criar, compartilhar.

\section{1- Pesquisar.}

$\mathrm{Na}$ primeira fase, os estudantes devem pesquisar maneiras de se resolver um problema experimental.

Nesta fase se dá o planejamento da atividade e das ações que deverão ser tomadas.

\section{2- Desenvolver.}

Nesta fase, há a aplicação do planejamento elaborado na fase anterior. Aqui, acontece a tomada e a análise de dados, ou seja, a resolução do problema experimental, propriamente dito.

3- Criar.

Nesta fase, o problema experimental já está resolvido e os alunos se ocupam em criar uma maneira de transformar as conclusões a que chegaram pela resolução do problema numa apresentação a ser compartilhada com a classe.

\section{4- Compartilhar.}

Nesta fase, há apresentação dos resultados obtidos com a classe. Aqui acontece a socialização do conhecimento.

Foram desenvolvidas outras estratégias didáticas para as atividades experimentais de ciência. Podemos citar a "Predict-Observe-Explain" (POE) e a “Think-Pair-Shore" (TPS) (White e Gunstone, 1992 apud Lunetta, 2007) que fazem com que os alunos elaborem hipóteses a respeito de fenômenos estudados no laboratório didático. Em ambas as estratégias, os alunos podem se reunir em pequenos grupos, elaborar hipóteses em relação ao fenômeno estudado, chegar as suas conclusões e as comunicar para a classe.

Gil \& Castro (1996) criticam certa visão do trabalho experimental que só se preocupa com a construção de aparelhos e aparatos experimentais, bem como a obtenção de medidas de grandezas físicas. Para os autores, esta é uma visão deformada do trabalho científico que gera nos alunos, um olhar meramente empirista do fazer ciência. 
Para superar esta concepção, eles propõem alguns elementos que devem nortear as atividades experimentais na sala de aula, os quais são colocados abaixo, juntamente com alguns comentários que ligam estes elementos com a nossa pesquisa:

1- Apresentar situações problema abertas, com um nível de dificuldade adequado, para que os alunos possam tomar decisões que transformem estes problemas abertos em situações precisas.

Uma situação aberta é aquela na qual não há um único caminho a seguir. Não há uma única "resposta certa". Nesta condição, os estudantes devem mobilizar recursos e conhecimentos para resolver tal problema. É fundamental que o nível de dificuldade seja adequado ao grupo com que se está trabalhando, pois um problema muito simples é resolvido muito rapidamente sem que haja realmente uma mudança conceitual ou epistemológica no aluno (Gil \& Castro, 1996). Um problema muito difícil, por sua vez, cria uma paralisia intransponível, que só é superada se o professor não só orientar, mas dirigir todos os passos da resolução, o que faz com que se caia no laboratório tipo "receita de bolo".

Este problema aberto deve ser transformado numa situação precisa pelos alunos, ou seja, após a realização do trabalho, devemos ter uma situação muito bem definida, mas agora, não só pelo professor, mas pelas equipes de trabalho, orientadas pelo professor.

2- Favorecer a reflexão sobre a relevância e o interesse das situações propostas, incluindo possíveis ligações entre ciência, tecnologia e sociedade.

É importante que o problema seja socialmente relevante e que a sua resolução leve os estudantes a perceber a ciência como algo integrado à sociedade e ao seu tempo. Os problemas não são atemporais e descontextualizados, mas sim fazem parte de um dado momento histórico (Gil \& Castro, 1996).

3- Potencializar as análises qualitativas que ajudem a compreender o fenômeno estudado, sem negar o papel fundamental da matemática, como instrumento de investigação.

Numa atividade escolar experimental tradicional, pouca ênfase se dá aos aspectos qualitativos da questão e o foco principal está nas medidas e obtenção de 
constantes. A matemática aparentemente domina, porém é um domínio morto, sem significado. Não se está aqui negando a importância das medidas e da matemática, muito pelo contrário. O que se deseja enfatizar é a importância de uma análise qualitativa da situação, para que o fenômeno em si se torne mais evidente e aí sim, a matemática, como fator estruturante da física ganhe significado. (Gil \& Castro, 1996)

4- A elaboração de hipóteses deve ser a atividade central do trabalho, bem como a sua fundamentação e suas conseqüências.

Muitas atividades didáticas experimentais estão baseadas apenas na construção de habilidades manuais, tais como a manipulação de instrumentos e a capacidade de realização de medidas. Não se está aqui menosprezando a importância destas habilidades, porém, uma atividade que se propõe a levar os estudantes a uma enculturação científica, deve privilegiar a elaboração de hipóteses por parte dos estudantes como sua atividade central. Não se deve aqui confundir a elaboração de hipóteses com o "eu acho que", sem fundamento. Os estudantes devem aprender a fundamentar suas hipóteses em observações ou na teoria e a argumentar a respeito delas. Nesta concepção, a atividade deve ser desenhada para que haja possibilidade de argumentação e que esta possibilidade seja maximizada (Gil \& Castro, 1996).

5- A atividade deve permitir a elaboração por parte dos estudantes de seus próprios desenhos experimentais, dando à dimensão tecnológica a importância que ela merece no processo.

Quando o estudante tem a liberdade de escolher o caminho a seguir para a resolução de um problema, desenhando o processo experimental que vai levá-lo a este objetivo, ele está desenvolvendo habilidades cognitivas que não seriam desenvolvidas se o professor ou o manual de instruções dirigisse totalmente o trabalho (Gil \& Castro, 1996). O desenvolvimento destas habilidades faz parte do processo de enculturação científica.

6- A análise dos resultados deve ser privilegiada, à luz dos conhecimentos físicos disponíveis e das hipóteses levantadas.

Numa atividade didática experimental, muitas vezes, a análise de resultados se prende apenas à verificação de um dado resultado já conhecido que pode ou não ser encontrado através da atividade. Neste tipo de verificação, tem-se um resultado 
indiscutível e um procedimento que pretende confirmá-lo. Quando isto não acontece, invariavelmente as dúvidas recaem sobre o procedimento adotado e nunca sobre a validade do valor procurado, tido como correto a priori (Gil \& Castro, 1996).

Para que haja enculturação científica, não basta que os alunos levantem hipótese, faz-se necessário que estas hipóteses sejam levadas em consideração na análise dos resultados. É importante que o professor as leve em consideração, mesmo quando, elas levam a resultados diferentes dos aceitos pela ciência. Deste embate, focado na análise dos resultados de um problema experimental, pode advir um crescimento conceitual, procedimental e atitudinal do aluno (Gil \& Castro, 1996).

7- À luz desta análise, deve-se favorecer o replanejamento da atividade, aperfeiçoando-a.

Realizada a atividade, analisados os seus resultados à luz do conhecimento físico e das hipóteses dos alunos, os alunos têm condições de replanejar a atividade, aperfeiçoando-a, para, por exemplo, diminuir os erros experimentais ou para testar nova hipótese que por ventura surgiram na análise de resultados (Gil \& Castro, 1996).

8- Pedir um esforço de integração da atividade com outros conhecimentos.

A atividade deve integrar os conceitos estudados com outros, para que não haja a percepção de que os conhecimentos são isolados, sem contextualização.

9- A memória do trabalho deve receber atenção privilegiada.

Os autores defendem a idéia da importância da memória e comunicação do trabalho que poderia ser feita através de comunicações internas, jornais ou outras formas (Gil \& Castro, 1996).

10- Potencializar a construção coletiva do conhecimento, criando equipes de trabalho e integrando-as.

Uma das deformações muito comuns a respeito do trabalho científico é a idéia do "gênio solitário", do cientista isolado do mundo e trabalhando sozinho. Para combater este mito, é importante que o trabalho seja todo feito em equipe e depois socializado com toda a classe (Gil \& Castro, 1996). A aula deve ter uma configuração que privilegie primeiro o trabalho em pequenos grupos e depois a sistematização da 
atividade, conduzida pelo professor e com a participação de todos os alunos. Carvalho et al. (1998) mostra que esta configuração favorece a participação de todos e não só dos mais desinibidos. Mesmo que um aluno não participe da discussão final, ele teria a oportunidade de argumentar no grupo pequeno.

Estes dez itens, propostos por Gil e colaboradores nortearam a proposta da atividade colocada na nossa pesquisa, a não ser por uma diferença fundamental. Em todos os trabalhos estudados (Gil \& Castro, 1996, Gil et al. 1999, Gil et al. 2001) deste autor, a atividade experimental está colocada no início da sequiência de ensino e tem por finalidade construir conceitos. A atividade experimental proposta no presente trabalho está colocada no final da seqüência de ensino e tem por finalidade aplicar conceitos (conservação da quantidade de movimento). Este trabalho vai verificar se, mesmo com esta modificação fundamental, este tipo de atividade possibilita a argumentação por parte dos alunos.

Laburu (2003) alerta para os limites de uma abordagem muito aberta, propondo um estágio intermediário entre as propostas que colocam o professor como orientador de um trabalho de pesquisa, dando grande autonomia aos alunos e o ensino tradicional que trata as atividades experimentais como um "livro de receitas". Esta abordagem intermediária surge devido às dificuldades experimentais, conceituais e matemáticas dos alunos, o que muitas vezes dificulta ou paralisa o trabalho, o qual só é retomado com a influência direta do professor. Nesta abordagem, por vezes, o professor é o mediador do trabalho, mas, em outras, ele o direciona, por reconhecer que algumas dificuldades são intransponíveis pelos alunos sozinhos, num curto intervalo de tempo.

Esta concepção intermediária procura harmonizar a busca da autonomia dos estudantes, como diz o autor, "a la Gil", com outras necessidades do ensino de física e particularmente do trabalho experimental.

\subsection{Habilidades A Serem Desenvolvidas Pelos Alunos Num Contexto De Enculturação Científica}

Já há algum tempo, diversos pesquisadores têm colocado que mais importante do que se definir o que ensinar, é estar muito claro o porquê se ensinar tais conteúdos (Postman, 1995 apud Lunetta et al., 2007) ou em outras palavras, é fundamental que os 
objetivos da educação estejam claros e definidos e os conteúdos e estratégias educacionais estejam compatíveis com estes conteúdos.

Num processo de enculturação científica, não basta que a atividade didática experimental seja elaborada para, genericamente, levar os alunos ao universo das ciências. Faz-se necessário ter-se com clareza que habilidades e competências são desejadas no desenvolvimento dos alunos. Diversos autores se debruçaram sobre este tema e alguns trabalhos neste sentido serão apresentados aqui.

Em 1989, foi lançado nos EUA, o "Project 2061, Science for All Americans" (AAAS, 1989) que colocou alguns objetivos a serem alcançados pelo ensino de ciências. Mereceram destaque, neste trabalho as atividades experimentais.

1- Identificar problemas para investigação, sendo capaz de sugerir estratégias para o desenvolvimento desta investigação e resolver o problema experimental os quais, segundo este projeto, as atividades didáticas experimentais devem ser geradas com os seguintes objetivos:

a) Os alunos devem ser capazes de identificar e testar hipóteses.

b) Os alunos devem participar ativamente de todo o trabalho.

c) Os alunos devem exibir criatividade e curiosidade na investigação cientifica.

d) Os alunos devem se interessar pela investigação cientifica.

e) Comunicação e colaboração na investigação cientifica.

f) Ter objetivos, tomar decisões, desenvolver raciocínio analítico e reflexivo durante a investigação.

g) Usar conceitos científicos corretos durante a investigação.

h) Demonstrar entendimento da natureza da ciência e sua relevância elaborando procedimento, interpretando dados e chegando a conclusões.

i) Tomar e justificar decisões através de metodologia cientifica, análise de dados. 
j) Demonstrar um forte entendimento dos conceitos científicos fundamentais e não simplesmente a articulação isolada de fatos e o uso de algoritmos matemáticos para a resolução de problemas.

Segundo este projeto, o ensino de ciências deve ser articulado para que estes objetivos sejam alcançados até 2061 e para tanto, os currículos, a formação e o comportamento dos professores e todos os elementos integrantes da cadeia que gera o processo de ensino-aprendizagem.

Giddings et al., 1991 apud Lunetta et al. (2007), defendem em seus trabalhos que os estudantes devem desenvolver, ou as atividades didáticas experimentais devem propiciar que os estudantes desenvolvam algumas habilidades, a saber:

1- Habilidades relativas à performance: a atividade deve propiciar que o estudante aprenda a manipular materiais e equipamentos; fazer, organizar e guardar observações; tomar decisões a respeito da investigação e chegar a uma conclusão relativa à atividade.

2- Habilidades relativas à análise e interpretação: o próximo passo da atividade deve proporcionar aos estudantes a oportunidade de processar dados, determinar relações, discutir a limitação dos dados, procedimentos e observações e formular novas questões baseadas na investigação conduzida.

3- Habilidades relativas ao planejamento da atividade: antes da atividade prática, propriamente dita, o aluno deve aprender a articular questões, prever resultados, formular hipóteses a serem testadas e determinar quais os procedimentos experimentais que devem ser usados para testar a hipótese.

4- Aplicação dos resultados: após a análise dos dados e da conclusão o aluno deve aprender a fazer predições em novas situações e formular novas hipóteses.

Estas quatro fases do trabalho experimental também foram sugeridas por Kempa, 1986 Lunetta et al. (2007) no sentido de desenvolver habilidades nos estudantes relacionados ao "fazer ciência".

Hofstein e Lunetta (2004) sugerem algumas maneiras de se verificar se os estudantes conseguem desenvolver estas habilidades: 
- Exames práticos.

- Relatórios experimentais.

- Portfólios.

Muitos professores e alunos não dão o devido valor às atividades experimentais, argumentando que a participação dos estudantes neste tipo de atividade não gera um incremento significativo no resultado de um exame tradicional, envolvendo testes a serem resolvidos com "lápis e papel”. Hofstein e Lunetta (2004) mostraram que há uma fraca correlação entre o bom desempenho dos estudantes numa atividade experimental didática e o seu resultado num teste tradicional, sugerindo que o trabalho realizado num laboratório didático está mais relacionado com o desenvolvimento de habilidades e competências próprias desta atividade ("saber fazer"), que não são medidas pela maioria dos exames tradicionais. Estes exames, muitas vezes, ignoram os procedimentos e resultados dos trabalhos experimentais, idealizando situações e exigindo apenas memorização de fórmulas e determinação algorítmica de qual é a resposta correta, sem a menor preocupação com o processo ou com a análise de um experimento ou de uma situação complexa (Bryce e Robertson, 1985).

Esta situação gera uma separação, no ensino entre a aprendizagem de conceitos e a aprendizagem de procedimentos. Este tipo de ensino considera e mede a aprendizagem de conceitos apenas através de testes simples, nos quais não aparecem as discussões, os levantamentos e testes de hipóteses, os procedimentos de uma investigação científica, os quais ficam relegados a um segundo plano, ou colocados na situação de mera curiosidade, sem valor, pois "não cai na prova". Esta separação foi pontuada por Gitomer e Duschl, 1998 apud Lunetta et al. (2007) e continua atual, pelo menos no Brasil, pois uma análise de alguns dos principais vestibulares nacionais (FUVEST, por exemplo) mostra a pouca relevância que merecem as habilidade e competências procedimentais.

\subsection{O Papel Do Professor Durante Uma Atividade Experimental}

Alguns pesquisadores se ocupam do papel do professor e das perguntas que eles podem fazer aos alunos, durante a investigação. A postura de um professor durante 
uma atividade experimental é fundamental para que os objetivos propostos pela atividade sejam alcançados.

Se o objetivo é levar o aluno à enculturação cientifica, ou seja, fazer com que ele penetre no mundo dos cientistas, realizando uma investigação orientada, entendendo um problema experimental, elaborando e reelaborando propostas de resolução deste problema, levantando hipóteses, recolhendo dados que comprovem ou não estas hipóteses, chegando a conclusões e compartilhando estas conclusões com a classe, a postura do professor durante o processo deve ser tal que leve os alunos a alcançar objetivos planejados.

Assim, o professor não deve dar a resposta de pronto aos alunos, mas também não deve deixá-los à deriva sem saber o que fazer, nem por onde começar.

O professor deve, durante a investigação orientada, estimular os alunos a contar o que estão vendo e fazendo e depois, como eles podem explicar o que viram e fizeram (Windschitl, 2002).

O professor deve ainda formular questões para que os alunos articulem o que estão vendo ou falando com os conceitos científicos (Driver et al., 1997).

Penick et al. (1996) propõem que o professor faça perguntas para que o aluno tome consciência de alguns elementos importantes da investigação, a saber:

1- História do experimento - questões que façam os estudantes relatar o que fizeram e o que aconteceu:

\section{Exemplos:}

a) O que você fez...?

b) O que aconteceu quando você...?

2- Relações - questões que fazem os estudantes relacionar idéias, atividades, dados, etc.

a) Como isto se compara com...? 
b) O que todos estes procedimentos têm em comum?

3- Aplicações - questões que fazem com que os estudantes usem conhecimentos e conceitos em outros contextos:

a) Como esta idéia pode ser usada para...?

b) Que evidências nós temos para comprovar...?

4- Especulação - questões que fazem os alunos pensarem além das informações já obtidas:

a) O que aconteceria se você mudasse...?

b) Qual deve ser o próximo passo?

5- Explicações - questões que fazem aos alunos pensar na base das razões, processos e mecanismo:

a) Como você explica que...?

b) Que justificativa pode ser dada para...? 


\section{O ESTUDO DA ARGUMENTAÇÃO}

\subsection{A Teoria Da Argumentação}

Toulmin no seu livro "O Uso da Argumentação" (1958) estuda como as pessoas argumentam para construir um raciocínio lógico. O seu modelo é muito usado por educadores em ciência (Jimenez et. al., 2000) e de outras áreas para estudar a argumentação dos alunos em sala de aula.

O modelo de Toulmin identifica alguns componentes que constroem uma argumentação:

- Dados: Fatos que amparam uma reivindicação.

- Reivindicação: Conclusão cujo mérito está sendo estabelecido.

- Justificativa: Razões propostas que mostram a correlação entre os dados e a conclusão.

- Apoios: Suposições básicas, que quando unidas, suportam a justificativa.

Assim, a estrutura básica da argumentação é representada na sentença como:

Por que (dados), desde que (justificativas), por causa de (apoio), portanto (conclusão).

Toulmin identifica ainda outros dois fatores em argumentações mais complexas:

- Qualificadores: especificam as condições nas quais a reivindicação pode ser verdadeira.

- Refutadores: especificam as condições nas quais a reivindicação não é verdadeira. 
O esquema de Toulmin é útil, porém limitado, pois ele não leva em conta, por exemplo, a correção da afirmação, mas sim apenas se ela está logicamente construída. Além disso, sua análise é descontextualizada. Não há menção aos aspectos interacionais do discurso, nem em que contexto ele se realiza (Driver et al., 2000). Em uma aula de ciências, muitas vezes, os alunos fazem afirmações conceitualmente incorretas ou falaciosas, segundo a lógica formal, mas que constituem passos importantes na construção do conhecimento (Jimenez, 2000).

A relação social dentro do grupo no qual acontece argumentação o que abrange aspectos como argumentos implícitos, linhas de raciocínio que se desenvolvem sem linearidade e outras particularidades que fazem parte de uma argumentação real devem ser levadas em conta (Driver et al., 2000).

Um programa educacional que pretenda melhorar a argumentação dos estudantes requer não apenas um modelo cognitivo de argumento, mas também um entendimento das condições sociais e culturais nas quais estes argumentos se desenvolvem (Driver et. al.2000).

\subsection{A Ciência E A Argumentação}

Para se verificar o lugar da argumentação na ciência, é necessária uma tomada de posição epstemológica em relação à questão: “O que é ciência". Driver faz uma distinção clara entre o "mundo natural", considerado existente e real e o nosso conhecimento a respeito deste mundo. O mundo natural, real, existe, porém nós não temos acesso direto a ele. O nosso acesso se faz através do conhecimento, o qual nós construímos. Este conhecimento é uma construção humana, parcial e provisória (conceitos científicos sofrem transformações, como por exemplo, o conceito de gravidade que não é o mesmo na Gravitação de Newton e na Relatividade Geral de Einstein) (Driver et. al., 2000).

Esta distinção entre o mundo natural de um lado (realidade assumida) e o nosso conhecimento dele (construção) faz com que a visão da ciência, como sendo puramente empirista (o cientista "lê o livro da natureza" através dos dados obtidos) dê lugar a uma visão na qual a interpretação dos dados por um cientista ou um grupo de cientistas seja carregada de conceitos teóricos advindas dos conhecimentos anteriores daquele grupo 
social. Assim o conhecimento é construído através da interpretação dos dados e evidências na qual a argumentação exerce um papel fundamental, pois, quase sempre há diferentes interpretações possíveis para o mesmo fenômeno ou para os mesmos resultados obtidos experimentalmente. O conhecimento se constrói deste embate de argumentos e visões diferentes (Driver et. al., 2000).

Observações e experimentos não são a rocha sobre a qual a ciência é construída, mas eles são as bases da geração de argumentos que cientistas usam para construir conceitos e teorias. É a força dos argumentos que vai fazer com que um conhecimento seja aceito ou rejeitado (Driver et. al., 2000).

Muitas vezes, as disputas a cerca de um determinado conhecimento levam anos (até séculos) para serem resolvidas. Não é um único experimento, nem um único argumento que resolve a questão, mas sim o conjunto de evidências e argumentos, que sobrevivem ao teste do tempo.

Estes embates argumentativos podem ocorrer em diferentes níveis (Driver et al., 2000):

- Na mente do cientista.

- Dentro de um grupo de pesquisa.

- Na comunidade científica em geral.

- Dentro do domínio público.

\subsubsection{O Raciocínio Hipotético-Dedutivo}

Nesta seção, será revisado o trabalho de Lawson, no qual o autor discute a importância do raciocínio hipotético-dedutivo nas ciências. Segundo o autor (2002), não há descoberta sem hipótese e há um processo de seleção nas observações dos cientistas, seleção esta guiada por um foco de interesse. Ele até discute se o processo hipotéticodedutivo não estaria presente em todas as descobertas da ciência (2002).

Este processo hipotético-dedutivo proposto por Lawson tem algumas características. Para o autor (2002), a estrutura do pensamento hipotético-dedutivo 
possui algumas características comuns, como a presença dos termos "se", "então", "e", "mas" e "portanto".

Para exemplificar a presença desta estrutura, Lawson (2002) cita o trabalho de Galileu Galilei, publicado no livro "Sideral Messenger" onde o cientista revela o que estava pensando enquanto fazia observações com o seu telescópio e como ele chegou à conclusão que o planeta Júpiter possuía luas que girariam em torno dele. Neste trabalho, Lawson (2002) procura saber quais eram os conhecimentos prévios de Galileu. Estes conhecimentos estavam baseados na visão aristotélica, segundo a qual as estrelas estariam fixas na abóbada celeste, porém, Galileu acreditava na proposta de Copérnico que colocava o Sol como o centro do Universo, os planetas, inclusive a Terra, girando em torno do Sol e a Lua, um satélite da Terra, girando em torno desta. Este conjunto poderia fornecer a base para as hipóteses de Galileu.

Observações e pensamentos de Galileu

- Dia sete de janeiro

Galileu, observando o planeta Júpiter, notou a existência de três pequenas, mas brilhantes "estrelas", próximas ao planeta. Chamou-lhe a atenção o fato das "estrelas" estarem exatamente alinhadas com Júpiter, paralelas à eclíptica e serem mais brilhantes que as outras estrelas.

Leste

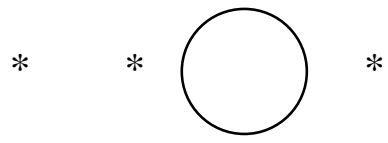

Oeste

Lawson (2002) procura analisar como Galileu estava pensando, enquanto fazia estas observações. Ele propõe a seguinte estrutura de pensamento:

Se... os três objetos são estrelas fixas (hipótese)

E... seus tipo, brilho e posição são comparáveis, entre si e com as estrelas próximas,

Então... variações de brilho, tipo e posição deveriam ser aleatórias, para o caso de estrelas fixas. 
Mas... elas parecem estar arranjadas exatamente em linha reta, paralela à eclíptica e são mais brilhantes que as outras estrelas.

Portanto... a hipótese das estrelas fixas não é confirmada.

No exemplo transcrito acima, Galileu partiu de uma hipótese inicial (os pontos brilhantes próximos de Júpiter são estrelas fixas) a qual correspondia ao seu conhecimento prévio. Havia uma expectativa relacionada a esta hipótese (as variações do tamanho, brilho e posição devem ser aleatórias) que não foi confirmada pelas observações orientadas no sentido de confirmar ou não a hipótese inicial. Como as observações não a confirmam, Galileu lança a possibilidade de ter havido um erro dos astrônomos e as suas observações são orientadas no sentido de confirmar esta hipótese, o que não acontece, surgindo aí a necessidade de uma nova hipótese (os pontos brilhantes em torno de Júpiter são satélites deste astro, ou seja, giram em torno dele da mesma forma que os planetas giram em torno do Sol) e esta hipótese é confirmada pelas observações.

Para Lawson (2004), a estrutura de pensamento das descobertas científicas obedece a esta seqüência e estão sempre presentes (explícitos ou não) os termos "se", "e", "então" e "portanto" se a hipótese inicial é confirmada e os termos "se", "e", "mas", "então" e "portanto" se a hipótese inicial é refutada.

O cientista parte de uma pergunta a qual gera uma hipótese que deve ser confirmada ou refutada por observações orientadas. Se a hipótese é refutada, ela deve ser substituída por outra que também deve ser testada através de observações orientadas.

\subsection{A Argumentação E O Ensino de Ciências}

\subsubsection{Introdução}

Vários autores têm se dedicado a buscar compreender como se processa a argumentação, tanto de alunos quanto a dos professores, em sala de aula.

Sutton, apud Driver e Newton (1997) ressalta o papel da comunicação e da linguagem no processo de ensino e aprendizagem. $\mathrm{O}$ autor ainda ressalta que, na sala de aula, os mesmos termos podem ter significados diferentes para pessoas diferentes e a 
análise do discurso pode aprofundar o entendimento de como as pessoas constroem significados e adquirem conhecimento.

Roth, 2002 coloca o discurso na sala de aula numa perspectiva na qual, a sala é uma comunidade de aprendizagem onde se estudam problemas autênticos, interessantes para os alunos e alunas e estes por sua vez assumem um papel ativo no processo, ao contrário das aulas onde predomina a transmissão-recepção que colocam os estudantes num papel extremamente passivo.

Para Carvalho (2007), a aprendizagem de ciências se assemelha a aprendizagem de uma nova cultura e este processo de enculturação científica se dá através da formação de significados das diversas linguagens das ciências. O estudo de como os estudantes se apropriam desta nova cultura só é possível através do estudo dos seus argumentos, já que não temos acesso direto aos seus pensamentos (Kuhn 1992).

Segundo Jiménez (2000), o estudo da argumentação dos alunos numa aula de ciências é importante, porque o processo de construção do conhecimento científico envolve práticas argumentativas. Para a autora, um aluno com a capacidade argumentativa desenvolvida é capaz de relacionar dados e conclusões, bem como avaliar enunciados teóricos. Esta avaliação é baseada em dados procedentes de observações, experimentos ou outras fontes.

Segundo Driver et al., (2000), a argumentação pode ser considerada como uma atividade individual, através do pensamento e escrita ou, socialmente feita em grupo.

A argumentação pode ser entendida como promover um raciocínio para ou contra uma proposição ou conduta (Driver et al., 2000). A autora, ainda, classifica os argumentos em retóricos ou dialéticos.

A argumentação descrita como retórica também por Kuhn (1992) é muito comum em sala de aula, pois é através dela que o professor normalmente se dirige à sala. Ele expõe um determinado conhecimento científico e procura convencer os alunos de sua validade. A argumentação retórica limita o aprendizado no sentido que não permite ao aluno desenvolver e praticar o seu próprio raciocínio. Para que este desenvolvimento aconteça, é necessário que a aula seja organizada de tal forma que o 
aluno tenha voz e oportunidade de praticar o seu próprio raciocínio (Driver et. al., 2000).

Outro tipo de argumentação é a dialética, na qual diferentes perspectivas e interpretações de um mesmo fato ou dado estão envolvidas. A argumentação dialética acontece na sala de aula quando os alunos têm a oportunidade de examinar, discutir e resolver um determinado problema (Driver et. al., 2000).

Se a argumentação faz parte do mundo científico, é importante que ela faça parte também da aprendizagem de ciências, na escola. Esta aprendizagem se faz de modo análogo à aprendizagem de uma língua estrangeira. É necessário que o estudante entenda os valores, conceitos e normas da cultura científica. Esta enculturação se faz através de atividades nas quais tenham a oportunidade de ler e ouvir a respeito desta nova cultura, mas também é importante que ele tenha a oportunidade de praticar, usando suas próprias idéias e aprendendo a desenvolver o seu próprio raciocínio (Driver et. al., 2000).

Uma forma de se obter tais resultados é planejar a aula de tal maneira a que os alunos tenham a oportunidade de resolver problemas que tenham várias respostas possíveis ou diversas interpretações para os mesmos resultados (Driver et. al., 2000).

O estudo das atividades voltadas à argumentação em sala de aula tem-se voltado ao estudo de três objetivos específicos (Driver et. al., 2000):

- O desenvolvimento de um entendimento conceitual.

- O desenvolvimento da capacidade investigativa.

- Elevar a tomada de decisão sobre problemas sócio-científicos.

1- O desenvolvimento de um entendimento conceitual.

Pesquisadores que trabalham nesta linha supõem que através do estudo do discurso dos estudantes em sala de aula podem-se obter informações de como os conhecimentos científicos são construídos pelos estudantes (Driver et al., 2000). Alguns grupos utilizam o modelo de Toulmin para analisar como o discurso é construído socialmente pelo grupo (Jimenez, 2000), ilustrando as falhas de suas estruturas, além de 
observar aspectos que não percebidos pelo esquema de Toulmin (operações epstêmicas e a influência da cultura escolar na argumentação dos alunos).

2- O desenvolvimento da capacidade investigativa.

O foco desta linha de pesquisa é a observação de como os estudantes resolvem problemas conceituais que exigem prática investigativa. Destaca-se nesta área, um extenso trabalho realizado por Richmon e Shriley, 1996 apud Driver et al.(2000) que discorre como seis grupos de quatro estudantes planejam, executa e interpreta experimentos projetados pelos estudantes que estavam no equivalente ao nível médio brasileiro, durante três meses. O trabalho se referia a uma epidemia de cólera ocorrida em Londres no século XIX e introduzia os estudantes aos conceitos básicos relacionadas à biologia celular e ao trabalho de detetive da ciência. Para os autores, há enculturação científica se os estudantes conseguem manipular e entender as ferramentas da ciência, bem como as idéias usadas na execução e interpretação dos experimentos. Os autores analisaram o entendimento dos estudantes tanto conceitualmente quanto socialmente. Percebeu-se que este entendimento foi crescendo durante o trabalho, bem como o seu envolvimento, além de que, os seus argumentos tornaram-se mais sofisticados. Foi verificada também a influência do líder do grupo no desenvolvimento do trabalho.

3- Elevar a tomada de decisão sobre problemas sócio-científicos.

A preocupação com a inclusão dos estudantes em problemas que envolvem Ciência, Tecnologia e Sociedade (CTS) está presente em diversos trabalhos no Brasil e no exterior, nos PCNs e em diversos currículos nacionais. Porém, muitas vezes o que se vê é que apenas existe o discurso do professor, não se dando oportunidade para que o estudante desenvolva suas próprias idéias sobre os temas tratados (Driver e Newton 1997). Ratcliffe (1996) apud Driver e Newton (1997) desenvolveu uma estrutura de seis passos para melhorar a tomada de decisão por parte dos estudantes (considerar opiniões, identificar critérios e escolher uma opção, verificar a veracidade de uma informação, considerar cada opinião, tomar uma decisão entre opiniões, refletir sobre o processo). Verificou-se uma melhoria no nível de tomada de decisão, através da análise dos argumentos dos alunos. 


\subsubsection{A Argumentação Dos Alunos Durante Atividades Experimentais}

Nesta seção, serão revisados, com mais detalhes que na seção anterior, alguns trabalhos a respeito da argumentação dos alunos, durante a realização de atividades experimentais em aulas de ciências no ensino fundamental e médio.

Driver et al., (2000) propõem um programa para desenvolver argumentação de alto nível de qualidade em sala de aula com os seguintes objetivos:

- Identificar as estratégias pedagógicas necessárias para promover ferramentas de argumentação aos jovens na sala de aula.

- Demonstrar a estratégia pedagógica e determinar quanto sua implementação aumenta a qualidade da argumentação em ciência.

- Determinar o quanto a prática, nas aulas que seguem esta estratégia, leva ao aumento da qualidade da argumentação dos alunos.

Driver e Newton (1997) propõem o instrumento abaixo para avaliar a qualidade dos argumentos:

Característica do argumento nível

Reivindicações competitivas sem argumentos

Reivindicações simples com argumentos

Reivindicações competitivas com argumentos

Reivindicações com argumentos e qualificadores

Reivindicações com argumentos respondidos por refutações

Fazer julgamentos integrando diferentes argumentos

Os autores (Driver e Newton, 1997) propõem também uma lista de checagem para avaliar o processo empregado pelos estudantes no encaminhamento da tarefa. Esta lista (provisória) deve orientar o professor no desenvolvimento de uma aula voltada para o desenvolvimento da argumentação dos alunos.

1- Examine a informação e evidência.

2- Questione cada razão. 
3- Examine a coordenação da evidência e reivindicação.

4- Construa sobre ela outros argumentos.

5- Monitore o envolvimento dos membros do grupo.

6- Encoraje a apresentação de idéias diferentes.

7- Diferencie reivindicações científicas de outras.

8- Reconheça os valores pessoais e sua influência nas decisões.

9- Empregue táticas que ajudem o processo do grupo.

10- Atente para a coordenação de diferentes perspectivas.

Locatelli (2006) propõe o estudo da argumentação dos alunos do ensino fundamental. Este trabalho se utiliza de atividades do conhecimento físico realizadas pelo LAPEF, as quais visavam levar os estudantes ao universo das ciências, dentro das suas capacidades, encarando a aprendizagem como atividades de investigação (Carvalho et al., 1998).

O seu objetivo é observar como as crianças constroem relações proporcionais e o raciocínio hipotético-dedutivo através destas atividades.

Foram escolhidas três atividades:

"1 Luz e sombras: "O problema das sombras no espaço";

2 Água: "O problema da pressão" e "O problema do submarino";

3 Conservação de energia: "O problema do looping" e "O problema da cestinha".,

(Locatelli, 2006, p.57)

Estas atividades, que correspondem a cinco aulas, foram gravadas e procurouse verificar, nas falas dos alunos, a existência do padrão hipotético-dedutivo proposto por Lawson, isto é, procurou-se verificar se nas falas dos alunos havia (explícita ou implicitamente), as palavras “se”, “e”, “então", “ mas" e "portanto", indicando que os alunos levantariam hipóteses através das observações, testariam estas hipóteses, refutando-as ou comprovando-as. 
Procurou-se também observar a existência das relações compensatórias através da presença das palavras "maior", "menor", "quanto mais" ou "quanto menos" nas falas dos estudantes.

Trabalhos anteriores (Carvalho et al., 1998) já haviam proposto que as falas dos alunos, durante a sua exposição, se dividem em duas fases distintas: a fase do "como" e do "porquê". Na fase "como", o aluno procura descrever o que ele fez ou o que ele observou. Na fase "porquê", há uma busca de uma explicação para o fenômeno observado. O professor, como condutor da discussão é quem faz esta divisão. É importante que o professor deixe que o aluno se expresse, pois se ele não passar pela fase do "como", não chegará ao "porquê" (Carvalho et al., 1998) e é aí que se manifesta o raciocínio hipotético dedutivo, como o manifestado por um aluno, quando a professora fez uma pergunta que continha "Por que?", na atividade "O problema da pressão." :

\footnotetext{
"Se entra ar, <então> ele se mistura com a água e <portanto> dá mais pressão pra água sair, porque se tampasse 〈então> não ia entrar ar e <portanto> não ia sair água, por causa que a água ia estar sem pressão”.
}

(Locatelli, 2006, p.123)

As palavras colocadas entre os símbolos $<>$ não foram usadas pelos alunos, mas estavam subentendidas. 


\section{PESQUISA}

\subsection{Pergunta}

Como os alunos elaboram um plano de trabalho para verificar se há ou não conservação da quantidade de movimento, numa situação proposta por eles mesmos; executam este plano e expõem para a classe o que fizeram e a que conclusão chegaram?

\subsection{Contexto}

Esta atividade foi realizada na Escola de Aplicação da USP, em turmas do primeiro ano do Ensino Médio. Cada turma tem trinta alunos e a sequiência de ensino é a proposta pelo GREF. Ao final desta seqüência, como aplicação dos conceitos construídos, foi colocada a atividade proposta aqui.

A sala é uma sala ambiente, com espaço para a experimentação e um espaço para a discussão ou exposição.

Os alunos são filhos de professores e funcionários da USP, logo, em sua procedência é basicamente da classe média e média baixa.

O professor tem vinte anos de experiência no Ensino Médio.

\subsection{A Sequência De Ensino}

Para melhor contextualização da atividade, será mostrada aqui a seqüência de ensino utilizada pelo professor e proposta pelo GREF. Cabe ressaltar que esta atividade não faz parte desta proposta e que pode ser utilizada em outras seqüências de ensino. A sequiência adotada pelo professor foi a seguinte:

1. Introdução à Física. Através da leitura de um texto (GREF) e da sua discussão, o professor procurou mostrar a relação entre a Física e mundo dos alunos, em diferentes aspectos. 
2. Mecânica. Através da leitura de um texto (GREF) e de sua discussão, o professor procurou fazer uma primeira introdução de conceitos relativos à mecânica (movimento, força, equilíbrio).

3. Movimentos. Através da leitura de um texto (GREF) e de sua discussão, o professor procurou fazer uma primeira introdução de conceitos relativos aos movimentos, mostrando que algumas coisas parecem não se mover sozinhas.

4. A conservação dos movimentos. Através da leitura de um texto (GREF) e de sua discussão, o professor procurou fazer uma primeira introdução de conceitos relativos às leis de conservação e é introduzida a lei da conservação da quantidade de movimento de uma maneira qualitativa.

5. Choques. Através da leitura de um texto (GREF) e de sua discussão, o professor procurou fazer uma primeira introdução de conceitos relativos aos choques. É introduzida a fórmula da quantidade de movimento. $(\mathrm{Q}=\mathrm{m} . \mathrm{v})$.

6. Exercícios. Os alunos resolveram alguns exercícios envolvendo choques, nos quais havia a conservação da quantidade de movimento.

7. Atividade proposta nesta pesquisa.

Devem-se fazer algumas observações a respeito desta seqüência:

a) Os alunos não trabalharam ainda os conceitos de cinemática, como a diferença entre velocidade média e instantânea. É aqui utilizado um conceito intuitivo de velocidade.

b) Este assunto foi trabalhado de forma escalar. Não foi introduzido o conceito de vetor, há apenas um tratamento escalar que coloca as velocidades e as quantidades de movimento como positivas ou negativas, dependendo do sentido do movimento.

A atividade, colocada neste momento, permite que o professor chame a atenção dos alunos para aspectos que serão retomados mais tarde como a diferença entre velocidade média e instantânea e faz com que o conceito de quantidade de movimento e da sua conservação se torne concreto, mesmo de uma forma ainda escalar, pois o conceito de vetor ainda vai ser trabalhado. 
Como o foco do trabalho do professor, neste momento são as leis de conservação, a atividade da nossa pesquisa é útil no sentido de se verificar os limites do princípio da conservação da quantidade de movimento. Os alunos poderão verificar que em certas situações, a quantidade de movimento se conserva em outras não, cabendo ao professor voltar a discutir estes limites e os seus porquês.

Cabe ressaltar que não é a seqüência ou o GREF que estão sendo analisados, mas sim a atividade e a argumentação dos alunos durante a mesma. Se esta atividade fosse trabalhada em outra sequiência, outras seriam as condições de contorno a serem levadas em conta.

\subsection{A Atividade}

Gil e Castro (1996) propõem alguns elementos que devem nortear as atividades experimentais em sala de aula, como já foi visto no presente trabalho. Laburu (2003), por outro lado aponta as limitações desta proposta de trabalho experimental. Ao mesmo tempo, autores como Driver et al., (2000) e Jiménez et al. (2000) ressaltam a importância de atividades experimentais que promovam ou possibilitem a argumentação dos alunos, o que não acontece nas atividades tradicionais (Driver et al., 2000). A atividade analisada nesta pesquisa está entre os pontos de vista de Gil e Laburu, pois procura contemplar os pontos colocados por Gil e Castro, mas reconhece as dificuldades colocadas por Laburu. Além disso, esta atividade tem como objetivo possibilitar a argumentação dos alunos.

A proposta da atividade estudada na nossa pesquisa é a realização de um trabalho experimental, no qual os alunos vão aplicar os conceitos relativos à conservação da quantidade de movimento. Os alunos deverão propor uma situação na qual pode haver ou não conservação da quantidade de movimento. Eles deverão também propor e aplicar um procedimento para testar a hipótese inicial (que na situação proposta por eles, há a conservação da quantidade de movimento).

O objetivo da atividade é fazer com que os conceitos (massa, velocidade, quantidade de movimento, conservação) sejam materializados numa situação prática proposta pelos próprios alunos. 
Numa atividade tradicional, fechada, o professor colocaria o objetivo, o procedimento, o material a ser utilizado e aos alunos caberia a tomada dos dados, a análise dos resultados e a conclusão. Nesta atividade, o professor coloca o objetivo e os alunos propõem uma situação e um procedimento, escolhem os materiais a serem utilizados entre alguns disponíveis, fazem as medidas que eles consideram necessárias, analisam os dados e testam a hipótese inicial.

Diversos autores (Gil e Castro, 1996; Borges et al., 2005) chamam a atenção para a importância de atividades experimentais onde os alunos têm a oportunidade de desenvolver os seus próprios desenhos experimentais, ou seja, atividades nas quais eles propõem os procedimentos a serem adotados na resolução de um problema aberto.

Nós acreditamos que uma atividade na qual os alunos devem propor uma situação experimental e desenvolver um procedimento para testar uma hipótese relacionada à situação escolhida por eles, além de tornar concretos os conceitos físicos envolvidos, permite aos estudantes testar hipóteses e desenvolver as suas habilidades argumentativas, elementos estes que devem fazer parte de um ensino comprometido com a introdução dos alunos no universo das ciências (Gil e Castro, 1996; Driver, 2000).

Esta atividade pode ser classificada como uma atividade experimental quantitativa (Araújo e Abib, 2003), pois os alunos deverão efetuar medidas e realizar cálculos para testar a hipótese inicial, pois reconhecemos a matemática como fator estruturante da física. Aqui, ao contrário do que acontece em atividades mais fechadas, a matemática não é um fim em si, nem as medidas a serem realizadas, pois estas são propostas pelos alunos e feitas para testar uma hipótese.

A atividade estudada consiste nas seguintes etapas:

1- Proposição pelo professor.

O professor apresenta alguns materiais aos alunos e propõe a estes, divididos em grupos de quatro ou cinco elementos, o seguinte problema:

"Usando alguns destes materiais, vocês deverão propor uma situação e analisar, fazendo as medidas que forem necessárias, se na situação escolhida por vocês, existe a conservação da quantidade de movimento" 


\section{Materiais:}

- Vários carrinhos

- Uma balança

- Uma trena

- Uma fita métrica

- $\quad$ Bolas de tênis

- Cronômetros

2- $\quad$ Trabalho em pequenos grupos.

Os alunos dividem-se então em grupos e passam a manipular materiais, relembrar os conceitos relativos à conservação da quantidade de movimento, propor situações e procedimentos e a fazer medidas para testar a hipótese inicial "a quantidade de movimento do corpo ou do sistema se conserva."

Nesta fase, o professor é o orientador da investigação, é aquele que vai trabalhar com os alunos junto com os materiais, os conceitos e a hipótese a ser testada. Ele deve orientar, relembrar conceitos, dirimir dúvidas, lançar questões, mas não deve dizer aos alunos o que eles devem fazer.

\section{3- Trabalho num grande grupo}

Nesta etapa, todos os alunos fazem uma grande roda e cada grupo apresenta o seu trabalho, retratando "como" o fez, descrevendo a situação e o procedimento escolhido, bem como as medidas realizadas e as conclusões a que o grupo chegou, ou seja, se houve ou não conservação da quantidade de movimento e "porque" (Carvalho et al., 1998). Nesta fase, os alunos devem mostrar se a hipótese inicial foi comprovada ou não e porque isto aconteceu.

Aqui, o papel do professor é o de mediador da discussão. 


\subsection{Metodologia De Pesquisa}

Nossa pesquisa é uma pesquisa qualitativa, a qual analisa o raciocínio dos alunos durante a realização de uma atividade experimental, através da transcrição das suas falas.

Para que esta transcrição seja feita, as aulas são gravadas em vídeo, possibilitando uma visão da dinâmica da sala, bem como as relações professor-aluno e aluno-aluno. Assim, a câmera de vídeo e a sala de aula são os elementos que possibilitam a tomada dos dados.

As gravações não são os dados da pesquisa (Carvalho et al., 2006). Estes são as transcrições das aulas, divididas em episódios de ensino.

A atividade é dividida em duas etapas. Na primeira, os alunos são divididos em grupos e trabalham em conjunto para a resolução do problema proposto. Nesta etapa, a gravação foi concentrada num único grupo, procurando-se captar as falas e ações dos alunos durante esta resolução, bem como as intervenções do professor, para que a atividade fosse bem sucedida.

$\mathrm{Na}$ segunda etapa, quando se formou uma grande roda e cada grupo pode descrever o seu trabalho e as suas conclusões, a gravação possibilitou captar a estrutura de pensamento dos alunos, através de suas falas. Iremos apresentar a análise das exposições de dois grupos dentre todos os que se apresentaram.

Cada etapa equivale a uma aula de quarenta e cinco minutos.

Foram escolhidas duas turmas ( 1 e 2 ) do primeiro ano do ensino médio para realizarem as atividades e em cada uma foram gravadas duas aulas de quarenta e cinco minutos totalizando três horas de gravação (uma hora e meia em cada turma). Iremos apresenta a análise da resolução do problema experimental e da exposição para toda turma de um grupo da turma 1, o qual será chamado de grupo A, bem como a análise das exposições para toda a turma somente de um grupo de alunos da turma 2, o qual será chamado de grupo B.

Cada etapa foi dividida em "episódios de ensino", momentos extraídos da aula nos quais ficam evidenciados alguns aspectos a serem estudados (Carvalho et al. 2006). 
"O episódio faz parte do ensino e é um recorte feito da aula, uma seqüência selecionada em que situações chaves são resgatadas."

(Carvalho, 2006 p.33)

Como exemplo de episódio de ensino, podemos citar uma parte da apresentação de cada grupo durante a segunda etapa da atividade, na qual os alunos procuram descrever o procedimento adotado por elas na resolução do problema experimental.

Para a análise da argumentação dos alunos, as falas serão apresentadas em tabelas de quatro colunas, cada uma com uma função:

\begin{tabular}{|l|l|l|l|}
\hline Turno & Tempo & Discurso & Observações/Ação \\
\hline
\end{tabular}

Na primeira coluna, está o turno de fala, colocado em ordem crescente, onde estão as falas relevantes para a resolução do problema de pesquisa deste trabalho. Cada intervenção de um aluno ou professor corresponde a um turno. Na segunda coluna, é apresentado o tempo decorrido do início da aula (correspondendo cada aula a uma etapa), podendo-se com isso, saber quanto tempo durou cada fala. Como foram colocadas apenas as falas relevantes dos alunos, por vezes, aparecem descontinuidades no tempo, entre um turno e o outro, pois entre estes dois turnos, houve falas ou ocorrências na aula que não são relevantes para esta pesquisa. Na terceira coluna estão as falas propriamente ditas ou ações correspondentes a cada turno. Na quarta coluna ficam os comentários, os quais procuram descrever melhor as ações ou as falas dos alunos e do professor, ressaltando-se em alguns casos a sua estrutura de pensamento, explícita ou implícita. Para isto, quando couberem as palavras "se", “e”, “mas”, "então", "portanto" e elas não estiverem explícitas, as mesmas serão colocadas entre os símbolos $<\ldots$..>. Exemplo : “<se> a quantidade de movimento se conserva...". Neste exemplo, a palavra "se" não foi dita, mas está implícita, segundo a estrutura proposta por Lawson 
(2002). Nesta coluna, por vezes também aparecem fotos que mostram as ações dos alunos.

Para tornar mais evidente o padrão de pensamento dos alunos, na análise dos episódios, recorreu-se à "paráfrase", ou seja, à reconstrução das falas, aglutinando-se turnos ou incluindo as palavras "se", "e", "mas", "então" e "portanto" quando elas estão implícitas e se estruturam conforme o padrão sugerido por Lawson (2002), mas com termos diferentes.

Nesta coluna, também, aparecem as nossas interpretações de algumas falas dos alunos. Neste caso, se, segundo nossa interpretação, alguns termos estão implícitos e não são os já citados acima, eles aparecem entre parênteses.

Caso a estrutura de raciocínio proposta por Lawson (2002.) seja observada em turnos distintos, apresentaremos o processo segundo a seguinte configuração,
Se ...
E...
Então...
E/Mas...
Portanto...

\subsection{Aspectos Éticos da Nossa Pesquisa}

Os alunos e o professor autorizaram o uso de suas imagens, única e exclusivamente para sua utilização nesta pesquisa. Estas autorizações estão em poder da escola, para preservar o anonimato dos seus participantes.

Ainda, para preservar o anonimato, nas transcrições, os nomes dos participantes foi trocado por outros fictícios. 


\section{ANÁLISE DE DADOS}

\subsection{Instrumentos De Análise}

A atividade estudada em nossa pesquisa tem como objetivo introduzir os alunos em alguns aspectos da enculturação científica. Diversos autores, como já vimos, mostraram como deve ser uma atividade didática experimental que se proponha a estes objetivos. Em nossa análise, vamos verificar, através das falas e ações dos alunos e do professor, se estes objetivos são cumpridos a contento. Para tanto, vamos dividir a atividade em duas etapas distintas e em cada etapa estabelecer critérios de análise apropriados para o que se espera em cada etapa:

\begin{tabular}{|c|l|}
\hline \multicolumn{1}{|c|}{ ETAPA } & \multicolumn{1}{|c|}{ Descrição } \\
\hline $\begin{array}{l}\text { E1- Resolução do } \\
\text { problema experimental } \\
\text { (aula 1) }\end{array}$ & $\begin{array}{l}\text { O professor propõe um problema } \\
\text { experimental e os alunos elaboraram e } \\
\text { realizaram um procedimento para testar a } \\
\text { hipótese da conservação da quantidade de } \\
\text { movimento na situação proposta pelos próprios } \\
\text { alunos. }\end{array}$ \\
\hline $\begin{array}{l}\text { E2- Apresentação da } \\
\text { resolução pelos alunos para a } \\
\text { classe }\end{array}$ & $\begin{array}{l}\text { Os alunos apresentam para a classe a } \\
\text { sua resolução do problema e o professor }\end{array}$ \\
& conduz esta apresentação. \\
\hline
\end{tabular}

Na etapa 1, predominam as ações e falas que levam à proposição, elaboração e resolução de um problema experimental. Nesta etapa, a nossa análise deverá se ater a indicadores próprios do fazer científico e do desenvolvimento da atividade, a saber:

A- Indicadores de desenvolvimento experimental

B- Indicadores de envolvimento com a atividade. 
C- Análise das fases porque passam os alunos para a solução do trabalho experimental.

D- As ações do professor.

A etapa 2 se caracteriza pela apresentação das soluções encontradas pelos alunos, por cada grupo para a classe toda. Esta apresentação foi mediada pelo professor e nesta fase a nossa análise procurou observar o comportamento do professor, bem como os argumentos dos alunos. Assim, nesta fase, nossa análise se aterá aos seguintes aspectos:

E- A argumentação dos alunos.

F- O entendimento dos conceitos envolvidos.

G- As ações do professor.

Agora, vamos descrever cada um destes aspectos que serão analisados em cada etapa.

\section{ETAPA 1}

A- Indicadores de desenvolvimento experimental

1- A capacidade de elaborar um procedimento para resolver um problema experimental.

O ensino de Física, muitas vezes, se reduz à resolução algorítmica de alguns exercícios pré-determinados, sem que os alunos consigam transpor estes exemplos para uma situação real, do cotidiano ou do laboratório. Uma das funções do laboratório didático experimental é fazer com que os estudantes consigam concretizar conceitos, ou seja, enxergar os conceitos teóricos (neste caso: velocidade, quantidade de movimento, lei da conservação da quantidade de movimento) em situações práticas. Na nossa análise, vamos verificar se os alunos conseguem fazer esta transformação, do abstrato (exemplo teórico) para o concreto (situação prática de laboratório).

Como já foi visto na nossa pesquisa, Rowe e Holland (1990) apud Lunetta et. al.(2007), descrevem a frustração dos alunos com as ciências, os quais a descrevem como um jogo que só pode ser jogado pelos cientistas. Para vencer esta frustração, 
diversos autores (Gil et al., 1999; Lunetta et al., 2007; Borges, 2005; Guridi e Islãs, 2003; Pizzini et al, 1989) propõem que uma atividade didática experimental deva dar aos alunos a possibilidade de elaborar um procedimento para resolver um problema.

O problema experimental colocado na atividade analisada na nossa pesquisa é aberto e quantitativo (Araújo e Abib, 2003).

Nesta atividade, os alunos montam uma situação, com os materiais a sua disposição.

Um grupo escolhe dois carrinhos e os joga um contra o outro para verificar se a quantidade de movimento é a mesma, antes e depois do cheque.

Outro grupo joga uma bolinha de tênis na parede e procura verificar se a quantidade de movimento da bolinha se conserva.

Outro grupo também jogou um carrinho contra o outro, só que um deles, há alguns livros em cima, para que as massas sejam diferentes.

Enfim, com os materiais a disposição, cada grupo de alunos mostra uma situação para verificar se a quantidade de movimento se conserva.

No problema experimental, os alunos vão testar uma hipótese. Esta habilidade é considerada como muito importante por diversos projetos de ensino (AAAS, 1989; PCNs, 1999).

Toda investigação científica começa com a elaboração de um plano de trabalho. Assim, introduzir jovens ao universo das ciências também significa capacitálos a elaborar um plano de trabalho no sentido de se conduzir uma investigação científica, mesmo que orientada pelo professor. Esta elaboração de um plano de trabalho, no nosso caso, significa elaborar um experimento que verifique se, na situação proposta pelos alunos, acontece a conservação da quantidade de movimento (hipótese a ser testada). Vamos verificar se, nesta atividade, os alunos demonstram esta capacidade.

2- $\quad$ A capacidade de reformular o experimento em busca de melhorar os resultados experimentais.

Gil e Castro (1996) defendem a idéia de que as atividades didáticas experimentais devem capacitar os alunos a replanejar seu plano de trabalho, no sentido 
de aperfeiçoá-lo, para diminuir erros experimentais ou testar novas hipóteses, por exemplo. Na nossa pesquisa, vamos verificar se os alunos apresentam a capacidade de reformular o experimento, durante a atividade, melhorando a tomada de dados.

3- A capacidade de obter os dados necessários.

Fazer medidas é uma característica típica das atividades experimentais, tanto didáticas quanto as realizadas por cientistas profissionais. Na nossa pesquisa, vamos verificar se os alunos têm a capacidade de obter dados num procedimento elaborado por eles mesmos.

A habilidade de tomar os dados necessários à resolução de um problema experimental é considerada importante no processo do ensino aprendizagem de Física por diversos autores como Lunetta et al., 2007; Pizzini et al., 1989; Giddings et al.(1991) apud Lunetta et al, 2007.

Neste item, vamos verificar se os estudantes são capazes de tomar os dados necessários na resolução do problema experimental proposto.

B- Indicadores de envolvimento com a atividade.

Jiménez et al. (2000) faz uma nítida distinção entre "fazer lição" e "fazer ciência”. Para que a segunda opção prevaleça sobre a primeira, o envolvimento dos alunos com a atividade deve acontecer.

Este envolvimento é considerado muito importante por diversos autores e tem sido sistematicamente estudado (Freitas da Silva, 2008).

Lunetta et al. (2007) mostram que os alunos gostam de atividades didáticas experimentais e que estas atividades aumentam o envolvimento dos estudantes com os assuntos científicos.

Os mesmos autores mostram que este envolvimentos é maior quando as atividades experimentais são abertas, ou seja, quando há um problema a ser resolvido.

Esta motivação foi estudada também por Guridi e Islãs (2003) através do desempenho dos estudantes durante uma atividade experimental. 
A forma de se verificar o envolvimento dos estudantes durante uma atividade experimental é objeto de estudo de Freitas da Silva (2008). Ele propõe dois indicadores de envolvimento com a atividade:

1- Expressões de satisfação.

2- Poucas conversas paralelas.

$\mathrm{Na}$ nossa pesquisa, propomos mais um indicador do envolvimento dos alunos com a atividade: a disposição de refazer o trabalho para se obter um melhor resultado. Se o objetivo dos alunos for apenas "fazer a lição" (Jiménez, 2000), eles se contentarão com a primeira resposta encontrada, mas se houver um real envolvimento, os alunos estarão dispostos a testar diferentes planos de trabalho ou diferentes soluções, para obter a melhor solução para o problema. Assim, além dos indicadores acima mencionados, propomos o seguinte:

3- A disposição de refazer alguma etapa do trabalho.

Assim, em nossa pesquisa, vamos verificar o envolvimento dos estudantes com a atividade através de três indicadores:

1- Expressões de satisfação.

2- Poucas conversas paralelas.

3- Disposição de refazer a atividade ou parte dela.

C- As ações do professor.

Na nossa análise, vamos estudar as ações do professor no sentido de orientar os alunos durante a investigação. Quais foram as suas ações no sentido de fazer os alunos avançar, qual o efeito destas ações nas falas e ações dos alunos e quando sua ação não se fez presente e qual o efeito disto no trabalho dos alunos.

D- Análise das fases porque passam os alunos para a solução do trabalho experimental.

Durante a realização de uma atividade, os alunos passam por diferentes fases. Carvalho et al. (1998) mostraram que numa atividade de investigação no ensino fundamental, os alunos primeiro manipulam os materiais, depois elaboram uma 
primeira solução, aplicam esta solução ao problema experimental a ser resolvido para então chegar a uma solução. Na nossa análise, procuramos verificar se no ensino médio, os alunos passam por fases semelhantes e se não, por que fases eles passam.

\section{ETAPA 2}

E- A argumentação dos alunos.

$\mathrm{Na}$ nossa análise, procuramos verificar a existência ou não da estrutura de raciocínio hipotético-dedutivo proposta por Lawson (2002) caracterizada pelas estruturas ("se", “e”, “mas", “então", “portanto").

Utilizamos, também, o modelo de Toulmin, para perceber a estrutura de pensamento dos alunos.

F- $\mathrm{O}$ entendimento dos conceitos envolvidos.

$\mathrm{Na}$ atividade analisada em nossa pesquisa, são trabalhados os seguintes conceitos pelos alunos:

1- Velocidade média.

2- Quantidade de movimento.

3- Conservação da quantidade de movimento.

A nossa análise procurou detectar, através das falas dos alunos, como os alunos aplicaram estes conceitos na atividade.

G- As ações do professor.

Windschitl (2002) e Driver et al. (2000) ressaltam a importância do professor saber elaborar questões que façam com que os alunos articulem conceitos científicos entre si e com a atividade experimental realizada. Na nossa análise, vamos verificar como o professor conduz a exposição dos alunos num grupo grande e quais os efeitos de suas intervenções nas falas dos alunos.

A nossa análise da ação do professor esta baseada na suas perguntas e intervenções durante exposição de cada grupo na aula.

Essas perguntas e intervenções são classificadas segundo os critérios definidos por Penick et al. (1996), ou seja, o objetivo de nossa análise é verificar se as perguntas e 
intervenções levam os alunos a tomar consciência dos seguintes elementos de seu trabalho:

1 - A historia do experimento - questões que façam os alunos a relatarem o que aconteceu.

2 - Relações - questões que façam os alunos relacionar idéias, atividades, dados, etc...

3 - Aplicações - questões que fazem com que os estudantes usem conhecimentos e conceitos em outros contextos.

4 - Especulações - questões que fazem com que os alunos pensem além das informações já obtidas.

5 - Explicações - questões que fazem com que os alunos pensem nas bases das razões, dos processos e dos mecanismos.

\subsection{Episódios De Ensino}

Os episódios estudados em nossa pesquisa são os seguintes:

Grupo A Aula 1 (resolução do problema experimental)

EP 1 Apresentação da atividade pelo professor.

EP 2 Manipulação dos materiais.

EP.3 Primeiras Tentativas de resolução

EP 4 Repetições.

EP 5 Reformulação do plano de trabalho.

EP.6 Elaborações do novo plano de trabalho

EP 7 Tomada de dados. 
Grupo A Aula 2 (exposição do grupo para a classe)

EP 8 Orientação da apresentação pelo professor.

EP 9 Primeira tentativa de exposição.

EP 10 Aperfeiçoamento da exposição.

EP 11 Ordenação das falas dos alunos.

EP.12 Conclusão da apresentação.

Grupo B Aula 2 (exposição do grupo para a classe)

EP. 13 Demonstração

EP. 14 Primeira tentativa de descrição do experimento

EP. 15 Descrição da reformulação do plano de trabalho

EP. 16 Primeira tentativa de relacionar o experimento com a conservação da quantidade de movimento

EP. 17 Relação entre o experimento e a conservação da quantidade de movimento

EP. 18 Conclusões dos alunos

Análise dos episódios

Grupo A

ETAPA 1 - Aula 1 (resolução do problema experimental)

\subsubsection{Análise do Episódio 1}

Apresentação da atividade pelo professor. 


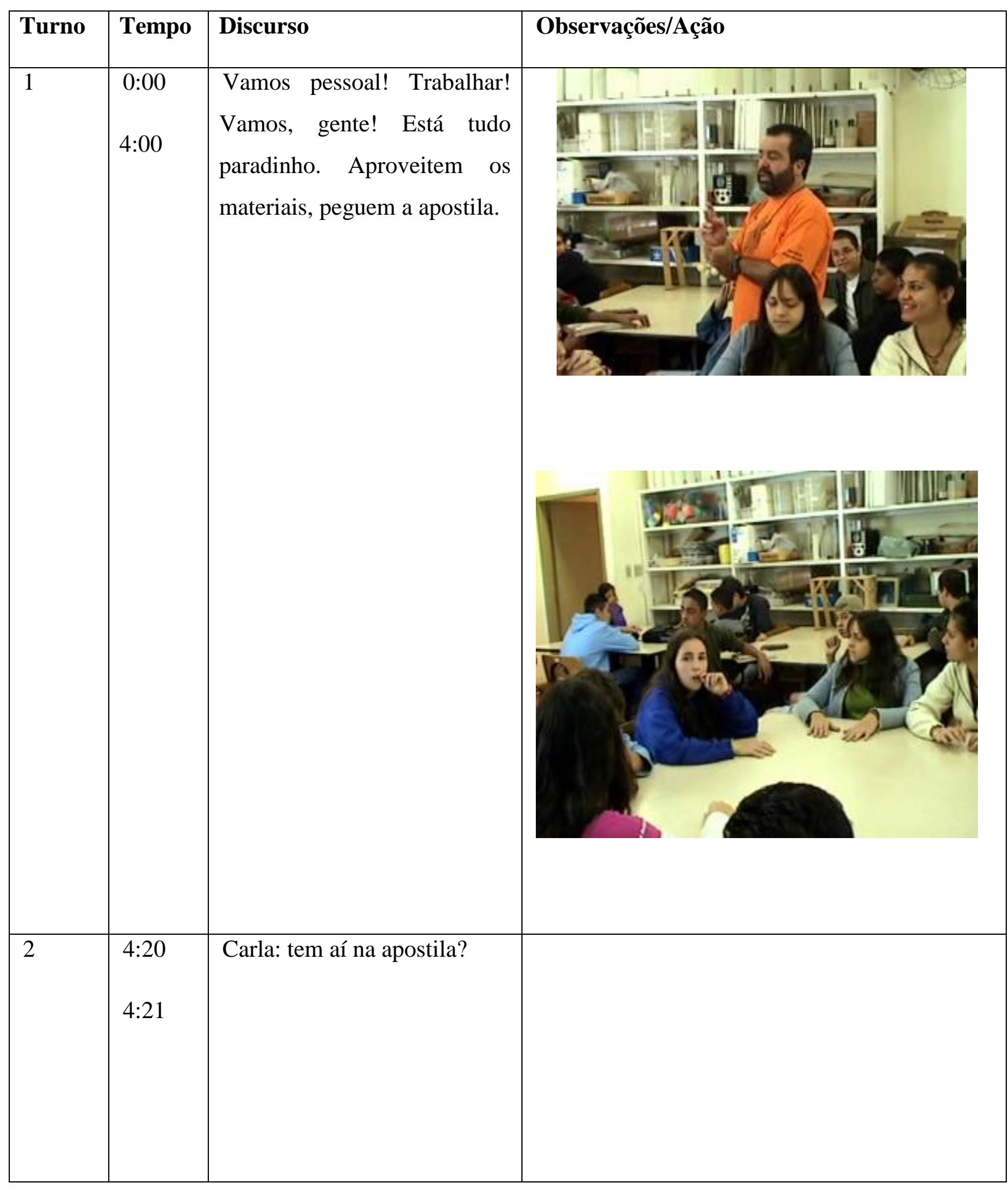




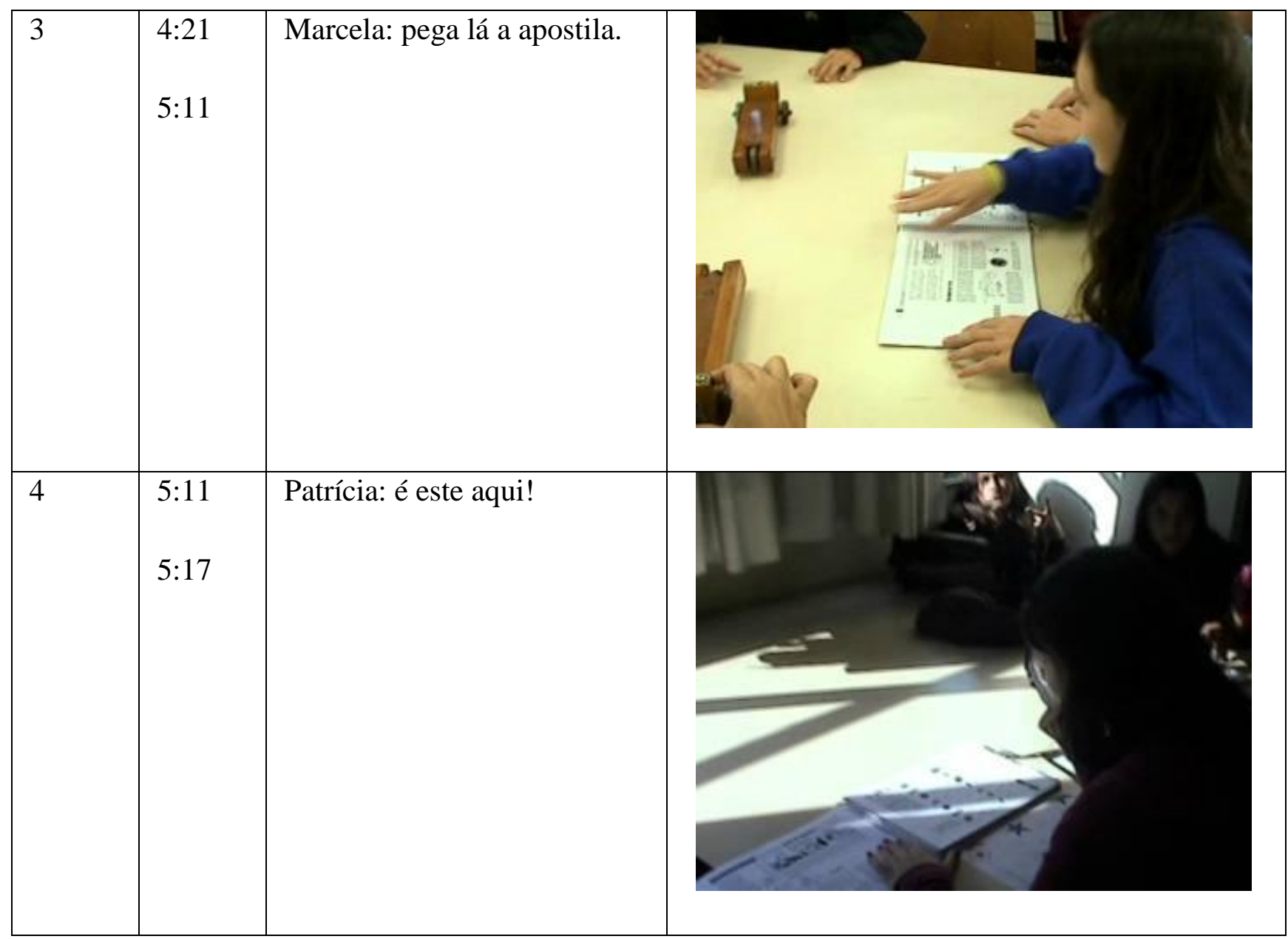

\section{Comentários}

O professor apresenta um problema a ser resolvido: os alunos devem, com os materiais apresentados, elaborar uma situação e, nesta situação, construir um procedimento para verificar se a quantidade de movimento se conserva. É um problema aberto, no qual o professor coloca um objetivo e os alunos devem testar uma hipótese, a conservação da quantidade de movimento na situação construída por eles. Inicialmente, o professor apresenta a atividade aos alunos. Ele diz aos alunos que devem se dividir em grupos de no máximo seis pessoas e cada grupo deve escolher alguns materiais, os quais estão disponíveis na classe.

Uma parte dos alunos se dedica a fazer uma pesquisa na apostila, reordenando os conceitos trabalhados em sala de aula e buscando um exemplo a ser trabalhado (“Tem aí na apostila?”). Podemos fazer uma analogia desta fase de trabalho com a pesquisa bibliográfica necessária a elaboração de uma pesquisa cientifica. Esta fase é que vai dar subsídios teóricos, para a elaboração do plano de trabalho. 


\section{Análise de dados}

Como este episódio se caracteriza pela apresentação do problema pelo professor, não são encontrados indicadores de desenvolvimento experimental, nem de envolvimento da atividade. O que pode ser verificado, por parte dos alunos é a primeira fase pela qual eles passaram durante esta atividade, a paralisia. Como não há um roteiro pré-estabelecido, os alunos, inicialmente ficam sem saber o que fazer. Esta paralisia pode ser verificada pela seguinte fala do professor: "Vamos pessoal! Trabalhar!... vamos, gente! Está tudo paradinho...” O professor, logo em seguida indica como os alunos podem começar o trabalho: "Aproveitem os materiais, peguem a apostila." Com estas duas orientações, o professor indica aos alunos dois caminhos a seguir:

\section{1- "Aproveitem os materiais"}

Com esta orientação, o professor estimula os alunos a manipular os materiais, para assim, darem um novo passo na investigação. O professor não diz o que os alunos devem fazer com os materiais, mas os incentiva a manipulá-los. Isto vai gerar esta ação em parte dos alunos, fazendo com que eles superem a paralisia e passem a manipular os materiais apresentados.

\section{2- "Peguem a apostila"}

Com esta orientação, o professor estimula os alunos a relembrar os conceitos já trabalhados em aula e a procurar um exemplo teórico que possa ser colocado em prática na atividade em questão. O professor não diz o que os alunos devem procurar na apostila, que fórmula usar ou coisas do gênero, mas ele os incentiva a fazer uma pesquisa teórica sobre o tema "conservação da quantidade de movimento".

B- Indicadores de envolvimento com a atividade - Não há nas falas dos estudantes indicações do envolvimento com a atividade, mas notamos expressões alegres dos componentes do grupo quando eles acharam na apostila um exemplo que poderia ser usado ("é este aqui"). Não se nota conversas paralelas no grupo neste momento, o que também indica o envolvimento com a atividade, segundo Freitas e Silva (2008). 


\subsubsection{Análise do Episódio 2}

\section{Manipulação dos materiais.}

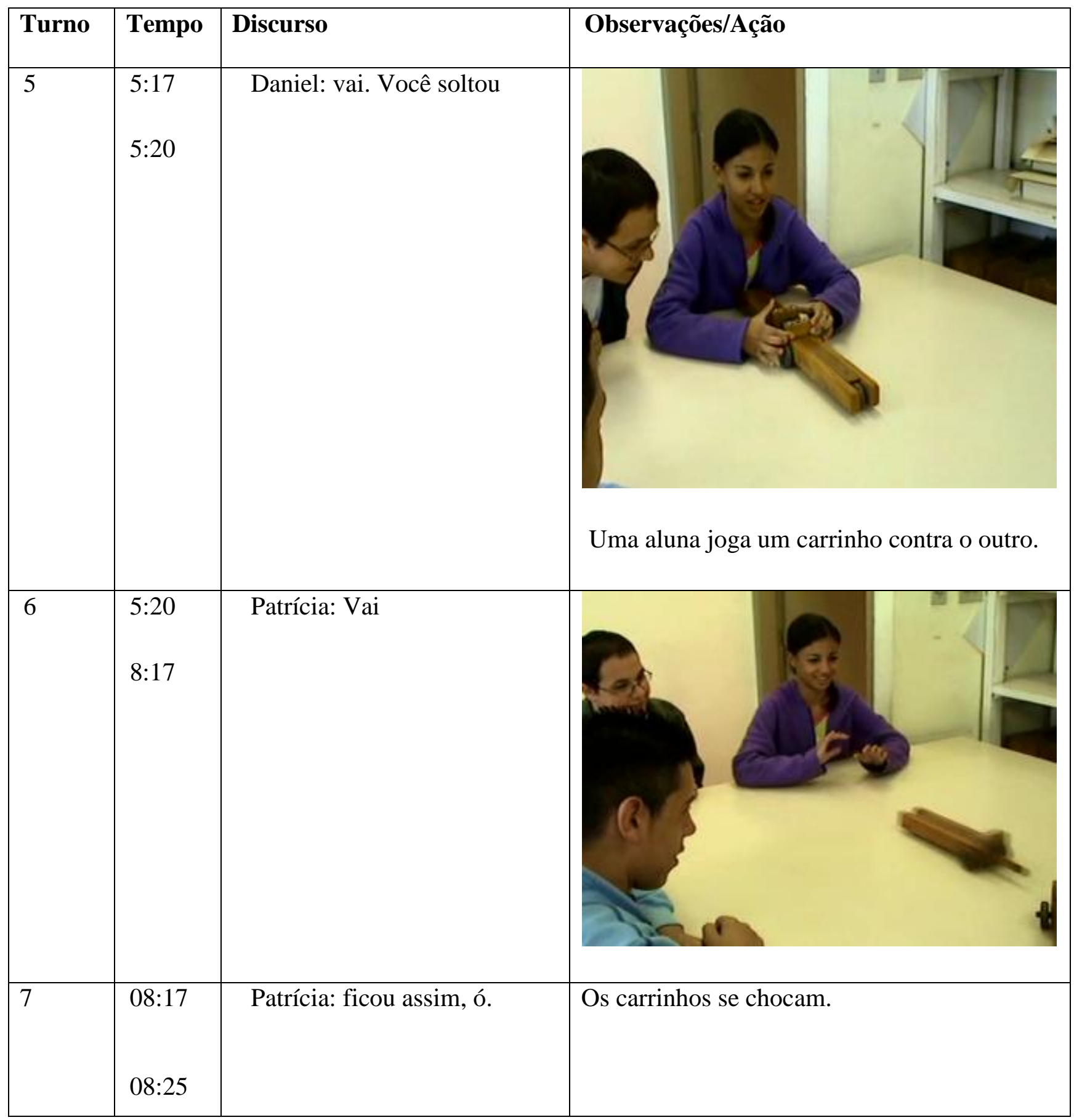

\section{Comentários}

Neste episódio, os alunos manipulam os materiais para conhecê-los. Dois carrinhos são lançados um contra o outro e os alunos observam o que acontece. Ainda não há tomada de dados, nem um plano de trabalho estabelecido, mas sim a vontade de 
conhecer os materiais colocados a sua disposição e de montar uma situação onde vai ser testada a hipótese da conservação da quantidade de movimento.

Carvalho et al. (1998) mostram que a fase de manipulação de materiais é muito importante numa atividade de investigação. Esta fase, aparentemente despretensiosa é de fundamental importância, pois é assim que vai acontecer a concretização dos conceitos importantes para a atividade (quantidade de movimento e sua conservação), bem como a gênese do plano de trabalho.

Este episódio é caracterizado por poucas falas dos estudantes e muita ação.

O envolvimento dos alunos com a atividade fica evidente quando se vê que eles jogam um carrinho contra o outro diversas vezes, procurando observar o que acontece e tentando obter um choque frontal. Se os alunos estivessem preocupados apenas em "fazer lição" (Jiménez et al., 2000, eles procurariam se desvencilhar rapidamente da tarefa e não se veriam as expressões de satisfação (Freitas e Silva, 2008) como se vê aqui, o que é um indicador do envolvimento com a atividade.

\subsubsection{Análise do Episódio 3}

\section{Primeiras Tentativas de resolução}

\begin{tabular}{|c|c|c|c|}
\hline Turno & Tempo & Discurso & Observações/Ação \\
\hline 8 & $\begin{array}{l}08: 44 \\
08: 46\end{array}$ & $\begin{array}{l}\text { Patrícia:...então alguém tem } \\
\text { que marcar. }\end{array}$ & $\begin{array}{l}\text { Uma aluna coloca o carrinho numa determinada } \\
\text { posição. }\end{array}$ \\
\hline 9 & $\begin{array}{l}08: 47 \\
08: 52\end{array}$ & $\begin{array}{l}\text { Carla:... peraí, tem que marcar } \\
\text { o tempo. }\end{array}$ & $\begin{array}{l}\text { Os alunos querem marcar o tempo decorrido entre o } \\
\text { lançamento dos carrinhos e o choque entre eles. }\end{array}$ \\
\hline
\end{tabular}




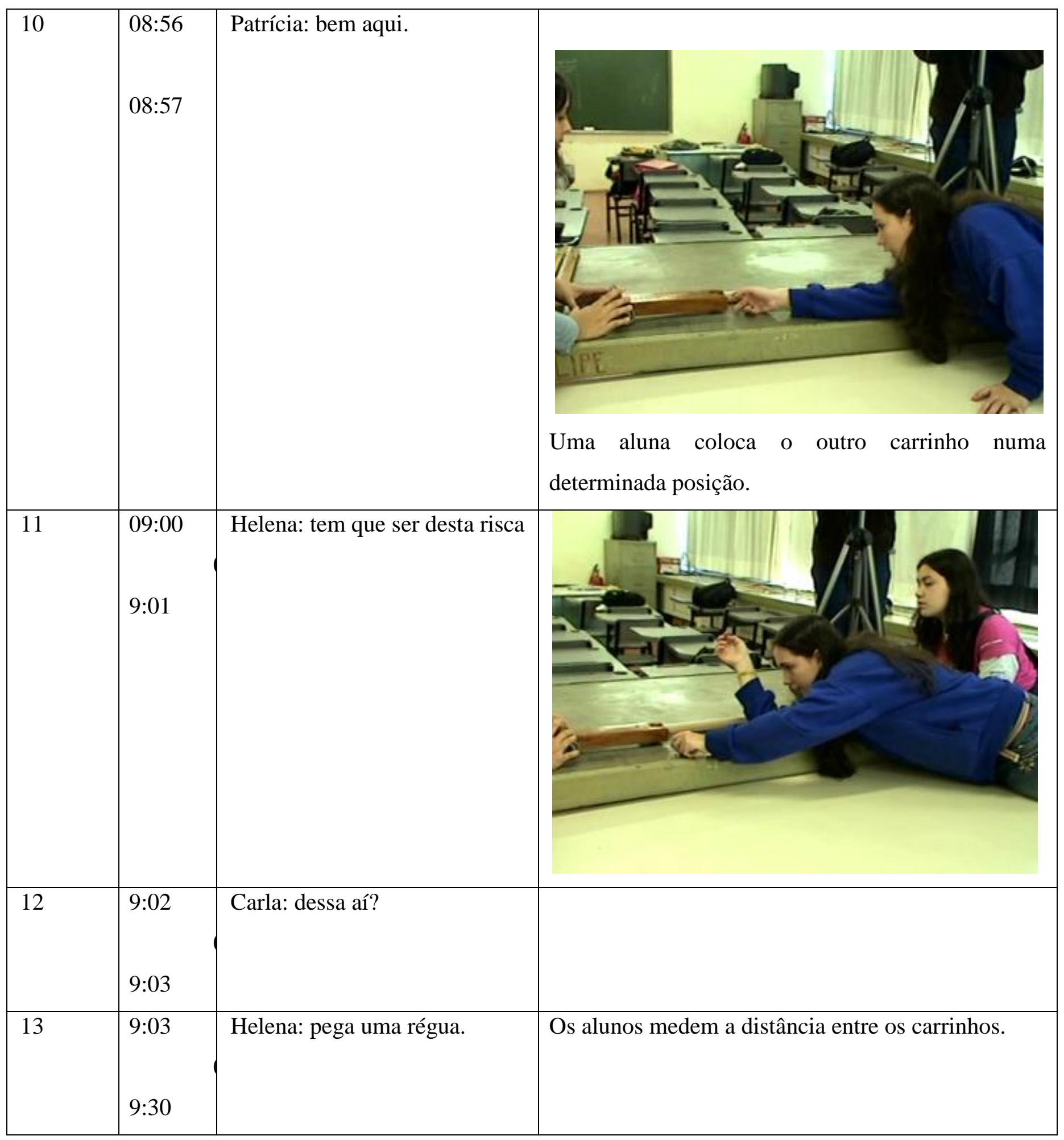




\begin{tabular}{|c|c|c|c|}
\hline 14 & $\begin{array}{l}9: 30 \\
9: 31\end{array}$ & Patrícia: um, dois, três e já! & Os alunos lançam os carrinhos um contro \\
\hline 15 & $\begin{array}{l}9: 31 \\
9: 32\end{array}$ & Carla: parou?! & Os carrinhos param antes de baterem. \\
\hline 16 & $\begin{array}{l}9: 32 \\
9: 35\end{array}$ & Patrícia: não bateu. & Os carrinhos não batem um contra o \\
\hline
\end{tabular}




\section{Comentários}

Os alunos escolhem uma situação e um plano de trabalho. A situação escolhida por eles é o choque frontal entre dois carrinhos e eles devem verificar se a quantidade de movimento do sistema de dois carrinhos é a mesma antes e depois do choque.

Para tanto, os alunos percebem que é necessário posicionar os carrinhos, medir a distância entre eles e medir o tempo decorrido desde o lançamento dos carrinhos até o instante do choque entre eles.

Não há menção neste plano de trabalho de que eles vão medir os tempos decorridos e distâncias percorridas pelos carrinhos após o choque.

Por enquanto, eles estão tentando gerar um choque frontal e fazer as medidas necessárias.

Para que o plano funcione, há uma serie de questões práticas, experimentais que devem ser resolvidas:

- o choque entre os carrinhos deve ser frontal.

- Devem-se medir as distâncias percorridas pelos carrinhos antes e após o choque.

- Deve-se medir o tempo no qual estes carrinhos percorrem essas distâncias, antes e depois do choque.

Estas necessidades e a forma de superá-la vão ficando claras à medida que o plano vai sendo colocado em prática, e os resultados positivos não acontecem na primeira tentativa.

\section{Análise de Dados}

A - Indicadores de desenvolvimento experimental.

Capacidade de elaborar um plano de trabalho.

Os turnos 8 a 11 mostram falas nas quais se percebe a execução de um plano de trabalho. Como este plano não foi proposto pelo professor, pode-se dizer que estes alunos foram capazes de elaborar um plano de trabalho, logo este indicador está 
presente. $\mathrm{O}$ fato dos alunos montarem a situação a ser analisada e escolheram a forma como os dados são obtidos está de acordo com os critérios de Guridi e Islãs (2003) de como uma atividade aberta deve ser elaborada.

Se os alunos são capazes de elaborar um plano de trabalho eles estão desenvolvendo a habilidade de resolver problemas experimentais o que é um dos objetivos a ser perseguido pelo ensino de ciências segundo Lunetta et al. (2007).

B - Indicadores de envolvimento com a atividade.

Poucas conversas paralelas.

Nas falas gravadas não há conversas paralelas, logo este indicador aparece neste episodio, conforme o critério proposto por Freitas da Silva (2008). A falta de conversas paralelas aliada à elaboração e execução de um plano de trabalho, indica que os alunos estão participando ativamente do trabalho, o que é um dos objetivos colocados para o ensino de ciências pelo AAAS (1989).

\subsubsection{Análise do Episódio 4}

\section{Repetições}

\begin{tabular}{|c|c|c|c|}
\hline Turno & Tempo & Discurso & Observações/Ação \\
\hline 17 & $\begin{array}{l}09: 50 \\
09: 52\end{array}$ & $\begin{array}{l}\text { Patrícia: um, dois, três e } \\
\text { já. }\end{array}$ & $\begin{array}{l}\text { ps alunos jogam os carrinhos um contra o outro, } \\
\text { procurando obter um choque frontal e obter os dados } \\
\text { referentes às distâncias percorridas pelos carrinhos e } \\
\text { o tempo que eles levaram até baterem. }\end{array}$ \\
\hline
\end{tabular}




\begin{tabular}{|c|c|c|c|}
\hline 18 & $\begin{array}{l}11: 41 \\
12: 00\end{array}$ & Marcela: bateram. & $\begin{array}{l}\text { Eles conseguem um choque frontal, mas não } \\
\text { conseguem obter o tempo decorrido do lançamento } \\
\text { do carrinho até o choque. }\end{array}$ \\
\hline 19 & $\begin{array}{l}12: 00 \\
12: 03\end{array}$ & $\begin{array}{l}\text { Patrícia: um, dois, três e } \\
\text { já! }\end{array}$ & Eles repetem o procedimento, mas não obtém um \\
\hline
\end{tabular}




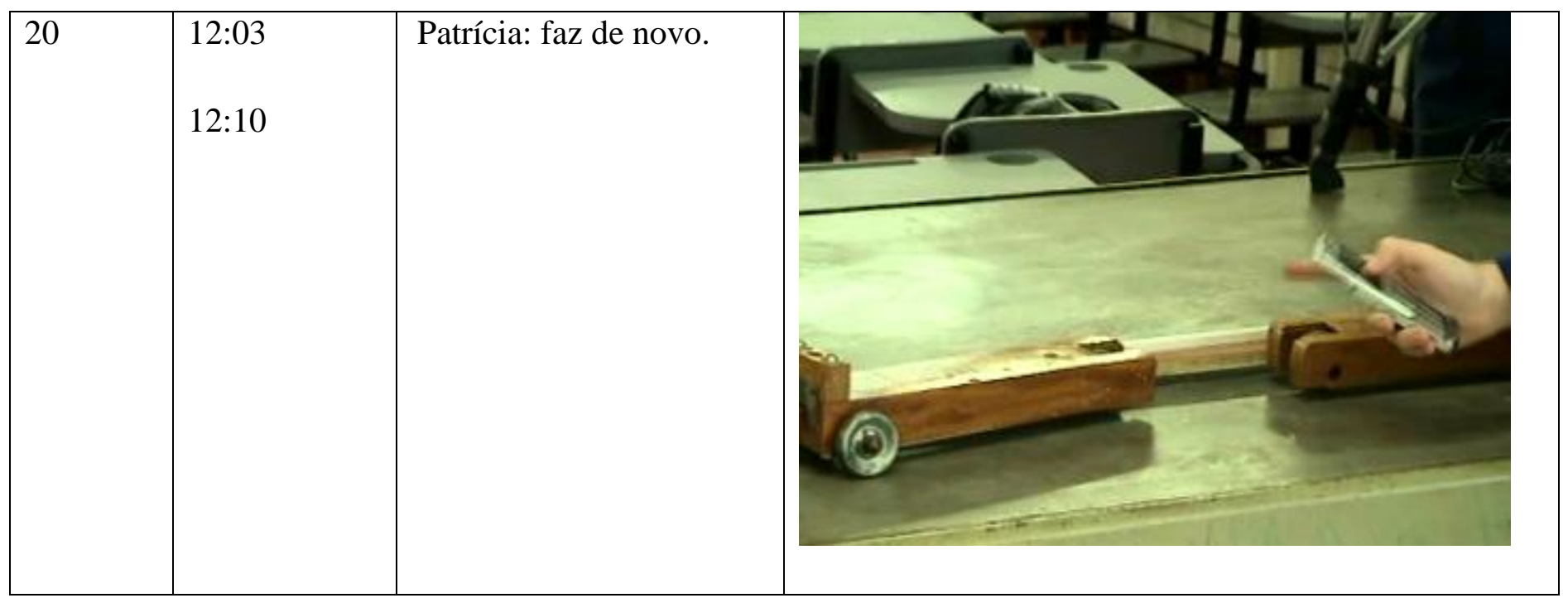

\section{Comentários}

Os alunos estão executando o seu plano de trabalho, mas sem sucesso. Existem problemas experimentais que não estão sendo vencidos pelo grupo. Estes problemas são:

- A dificuldade de se obter um choque frontal. Normalmente, os carrinhos após o choque não continuam na mesma reta.

- O tempo decorrido até o choque é muito curto, e às vezes, nem dá tempo do aluno responsável por esta medição se preparar e tomar os dados.

Estas dificuldades são próprias do trabalho científico e se os alunos as estão experimentando, eles estão tomando contato com o mundo dos cientistas, com a cultura cientifica, o que deve ser um dos objetivos a ser perseguido pelo ensino das ciências (Driver et al., 2000).

$\mathrm{B}$ - Indicadores do envolvimento com a atividade.

Mesmo com as dificuldades encontradas no desenvolvimento do procedimento experimental relativo ao plano de trabalho desenvolvido pelos alunos, não se notam conversas paralelas na gravação, o que é um indicador de envolvimento da atividade, segundo Freitas e Silva (2008).

Neste episódio, os alunos repetem parte do procedimento experimental (jogar um carrinho contra o outro). 
A disposição de refazer o procedimento ou parte dele.

Hofstein et al. (2001) mostram que o interesse dos alunos pelas atividades experimentais é maior se a atividade for aberta, ou seja, se há um problema a ser resolvido.

Num problema aberto, em que há a possibilidade de os alunos testarem diferentes formas de experimentação (Guridi e Islãs, 2003) esta disposição se traduz em “fazer ciência" e não apenas "fazer lição" (Jiménez et al., 2000), ou seja, o aluno quer resolver o problema e não apenas cumprir uma tarefa pré-determinada.

Para resolver um problema em que não há roteiro fechado, pré-determinado, é natural que as dificuldades experimentais apareçam como acontece neste episódio.

Aqui, os alunos desejam medir o tempo que cada carrinho percorre até o choque.

Neste episódio, eles não conseguem fazer isto na primeira tentativa, por isso repetem o procedimento (lançar um carrinho contra o outro e obter os dados necessários) por três vezes sem sucesso.

Segundo nossa análise, esta disposição de refazer esta parte do procedimento é um indicador de envolvimento na atividade. 


\subsubsection{Análise do Episódio 5}

Reformulação do plano de trabalho

\begin{tabular}{|c|c|c|c|}
\hline Turno & Tempo & Discurso & Observações/Ação \\
\hline 21 & $\begin{array}{l}12: 10 \\
12: 40\end{array}$ & $\begin{array}{l}\text { Daniel: por que não } \\
\text { deixa um parado? }\end{array}$ & Os alunos estão prontos para lançar novamente um \\
\hline 22 & $\begin{array}{l}12: 42 \\
12: 47\end{array}$ & $\begin{array}{l}\text { Daniel: por que não } \\
\text { deixa um parado? }\end{array}$ & $d x$ \\
\hline
\end{tabular}




\begin{tabular}{|c|c|c|c|}
\hline 23 & $\begin{array}{l}12: 47 \\
12: 49\end{array}$ & Patrícia: está certo. & Daniel segura um carrinho, impedindo que os \\
\hline 24 & $\begin{array}{l}12: 49 \\
12: 52\end{array}$ & 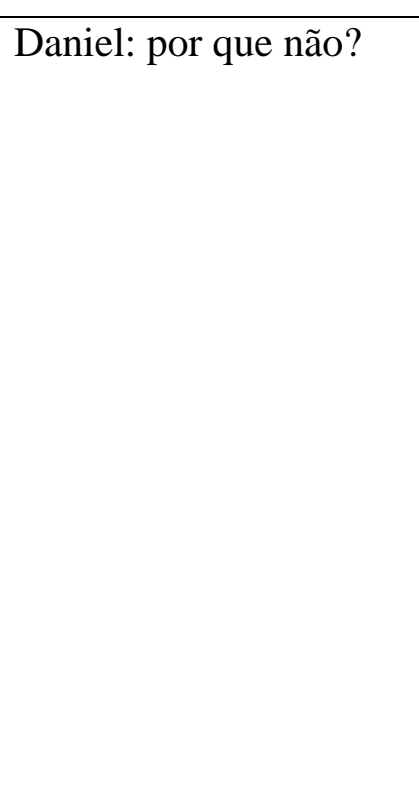 & $\therefore$ \\
\hline 25 & $\begin{array}{l}12: 52 \\
12: 53\end{array}$ & Daniel: acho mais fácil. & \\
\hline 26 & $\begin{array}{l}12: 53 \\
12: 54\end{array}$ & Luis: mesma coisa. & \\
\hline 27 & $\begin{array}{l}12: 54 \\
12: 56\end{array}$ & Daniel: lógico que não. & \\
\hline
\end{tabular}




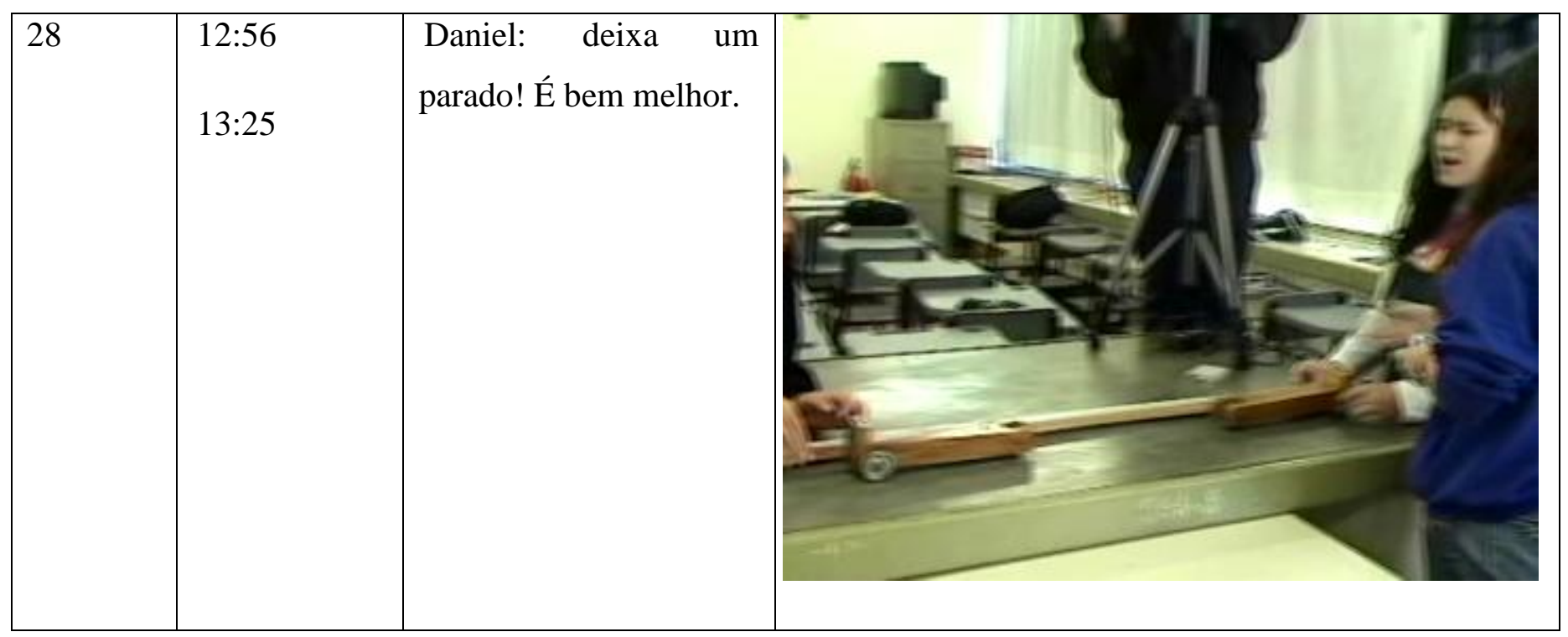

\section{Comentários}

Esta proposta de reformulação surge para facilitar a tomada de dados por parte do grupo. Se um carrinho está inicialmente parado, não é necessário que um aluno marque o tempo que ele demorou em encontrar o segundo carrinho, antes do choque. Além disso, a posição do choque, desta maneira ficou muito bem definida, mesmo antes dos carrinhos serem lançados, facilitando a sua medição, o que não acontece quando os carrinhos são lançados um contra o outro. Mesmo a medição do tempo que o segundo carrinho levou para encontrar o primeiro é facilitada porque, com um dos carrinhos parados, este tempo é maior do que seria com os dois carrinhos em movimento, diluindo-se o tempo de reação e aumentando a precisão desta medida.

Resumindo, esta nova proposta de trabalho tem as seguintes vantagens em relação à proposta anterior:

a) Não é preciso medir o tempo ou o deslocamento do primeiro carrinho antes do choque, já que ele esta parado;

b) A posição do choque está bem determinada, antes do lançamento do segundo carrinho, facilitando a medição do deslocamento deste, antes do choque;

c) Como o tempo necessário para que os carrinhos se choquem é maior que na metodologia anterior, este pode ser medido com maior precisão.

É importante notar que o aluno que propôs esta modificação não havia aparentemente participado da atividade. Entretanto, sua participação neste episódio 
gerou uma reformulação na forma como que os alunos estavam trabalhando, reformulação esta que possibilitou a tomada de dados por parte do grupo, como veremos adiante, o que ainda não havia acontecido.

Outro aspecto interessante neste episódio é a forma com que aconteceu esta reformulação.

Apesar das vantagens da nova metodologia sobre a antiga, ela não foi aceita de imediato pelo grupo, muito pelo contrário, este aluno foi de inicio ignorado pelo grupo.

Ele repete a pergunta, esperando ser ouvido.

Depois que ele consegue ser ouvido, há uma breve discussão entre ele e outros componentes do grupo.

Cabe notar que os argumentos usados de ambas as partes, foram todos sem justificativa, nível zero na classificação de Driver e Newton (1997).

Mas, então, como este aluno, sem ter participado ativamente dos trabalhos, até aquele momento e sem uma argumentação elaborada, conseguiu mudar um procedimento que havia sido longamente trabalhado pelo grupo até então?

Ele utilizou uma estratégia muito simples, eficiente e muito usada em disputas, cientificas ou não, pela sociedade: a força. Ele segurou um dos dois carrinhos e se colocou na mesa de tal forma que nenhum carrinho pudesse ser lançado. Ele só soltou o carrinho quando sua idéia foi testada.

\section{Análise de dados}

A- Indicadores de desenvolvimento experimental

Neste ponto do processo, o plano original de trabalho já foi posto em prática e repetido algumas vezes, sem que os alunos tenham conseguido obter os dados necessários. Um aluno propõe uma mudança procedimental para facilitar a tomada de dados.

Eles tiveram a oportunidade de testar uma forma de experimentação e agora discutem uma nova forma, um novo procedimento para continuar o experimento. Segundo Guridi e Islãs, (2003) uma atividade didática experimental deve proporcionar 
aos estudantes esta oportunidade, aproximando-os do mundo real dos cientistas, o que deve ser um dos objetivos dos alunos de ciências (Driver et al., 2000).

A discussão a respeito de o caminho a seguir, na atividade experimental, leva os alunos a uma tomada de decisão a este respeito (AAAS, 1989), assim, a reformulação do plano de trabalho, que acontece neste episódio é um indicador de desenvolvimento experimental.

B- Indicadores de envolvimento com a atividade.

Neste episódio todas as falas gravadas dizem respeito à atividade, o que é um indicador do envolvimento dos alunos com a atividade, segundo Freitas da Silva (2008).

No presente episódio, também há uma discussão a respeito do melhor caminho a seguir, ou seja, os alunos estão dispostos a reformular o seu plano de trabalho, se for preciso, para melhor obter os dados necessários. Esta situação, típica do trabalho dos cientistas aproxima-os deste universo. Em outras palavras, os alunos se mostram dispostos a "fazer ciência" e não só "fazer lição" (Jiménez et al. 2000), o que segundo nossa análise é um indicador de envolvimento dos alunos com a atividade.

\subsubsection{Análise do Episódio 6}

Elaboração do novo plano de trabalho

\begin{tabular}{|l|l|lcc|}
\hline Turno & Tempo & Discurso & Observações/Ação \\
\hline 29 & $13: 25$ & Patrícia: já! & & \\
& & &
\end{tabular}




\begin{tabular}{|c|c|c|c|}
\hline 30 & $\begin{array}{l}13: 26 \\
13: 42\end{array}$ & Carla: Aqui. & Os dois carrinhos se chocam e Carla indica de onde \\
\hline 31 & $\begin{array}{l}13: 49 \\
14: 50\end{array}$ & $\begin{array}{l}\text { Carla: um cronometra } \\
\text { só aquele. Um } \\
\text { cronometra só este. }\end{array}$ & $\begin{array}{l}\text { Os alunos se organizam, para que os tempos sejam } \\
\text { medidos. Um aluno se responsabiliza por um } \\
\text { carrinho e outro por outro carrinho. }\end{array}$ \\
\hline 32 & $\begin{array}{l}14: 50 \\
14: 55\end{array}$ & $\begin{array}{l}\text { Patrícia: como vai } \\
\text { medir? }\end{array}$ & 15 \\
\hline 33 & $\begin{array}{l}14: 55 \\
15: 05\end{array}$ & $\begin{array}{l}\text { Carla: a hora que ele } \\
\text { parar, eu paro }\end{array}$ & $\begin{array}{l}\text { Carla sugere medir o tempo decorrido até que o } \\
\text { carrinho pare. }\end{array}$ \\
\hline
\end{tabular}




\begin{tabular}{|c|c|c|c|}
\hline 34 & $\begin{array}{l}15: 05 \\
15: 12\end{array}$ & $\begin{array}{l}\text { Patrícia: a hora que ele } \\
\text { bater, você dá uma } \\
\text { pausa. Depois, você } \\
\text { deixa rodando para ver } \\
\text { onde vai parar de vez. }\end{array}$ & $\begin{array}{l}\text { Patrícia diz a Carla que ela deve médio dois } \\
\text { tempos: o tempo que o carrinho leva para percorrer } \\
\text { certa distância antes e o tempo decorrido depois do } \\
\text { choque e não só o tempo total. }\end{array}$ \\
\hline 35 & $\begin{array}{l}15: 12 \\
16: 02\end{array}$ & $\begin{array}{l}\text { Carla: você vai } \\
\text { anotando as idéias, } \\
\text { heim. }\end{array}$ & $\begin{array}{l}\text { Uma pessoa fica responsável por anotar todas as } \\
\text { idéias que estão sendo discutidas. }\end{array}$ \\
\hline 36 & $\begin{array}{l}17: 26 \\
18: 06\end{array}$ & $\begin{array}{l}\text { Patrícia: Oh, Carol, } \\
\text { você tira esta régua } \\
\text { daqui. Vai Marcos. }\end{array}$ & $\begin{array}{l}\text { O local onde acontece o experimento é limpo de } \\
\text { outros objetos ou obstáculos. }\end{array}$ \\
\hline
\end{tabular}




\begin{tabular}{|c|c|c|c|}
\hline 37 & $\begin{array}{l}18: 06 \\
18: 14\end{array}$ & Daniela: E aí? & $\begin{array}{l}\text { Um carrinho é lançado contra o outro que estava } \\
\text { parado. }\end{array}$ \\
\hline 38 & $\begin{array}{l}18: 14 \\
18: 18\end{array}$ & $\begin{array}{l}\text { Patrícia: Você marcou } \\
\text { os dois tempos? }\end{array}$ & \\
\hline 39 & $\begin{array}{l}18: 18 \\
18: 20\end{array}$ & $\begin{array}{l}\text { Marcela: Não. Na hora } \\
\text { que ele bate, tem que } \\
\text { parar? }\end{array}$ & $\begin{array}{l}\text { Marcela não entendeu que deveria marcar dois } \\
\text { tempos (antes e depois do choque). }\end{array}$ \\
\hline 40 & $\begin{array}{l}18: 20 \\
18: 28\end{array}$ & $\begin{array}{l}\text { Patrícia: } \mathrm{Na} \text { hora em } \\
\text { que ele bate, tem que } \\
\text { parar uma vez. Na hora } \\
\text { em que ele parar, tem } \\
\text { que parar de novo. }\end{array}$ & $=4$ \\
\hline 41 & $\begin{array}{l}18: 28 \\
19: 10\end{array}$ & $\begin{array}{l}\text { Carla: vem aqui um } \\
\text { pouquinho. }\end{array}$ & \\
\hline
\end{tabular}




\begin{tabular}{|c|c|c|c|}
\hline 42 & $\begin{array}{l}19: 10 \\
19: 15\end{array}$ & Marcela: Deu? & $\begin{array}{l}\text { O carrinho é lançado novamente e desta vez cada } \\
\text { aluno cumpriu o seu papel e agora é possível se } \\
\text { obter os dados, de acordo com o plano dos } \\
\text { estudantes. }\end{array}$ \\
\hline
\end{tabular}

\section{Comentários}

Os alunos acatam a sugestão de Daniel e deixam um carrinho parado e lançam o outro em direção ao primeiro.

Agora, existem questões de organização que devem ser resolvidas:

1 - Quem vai medir o tempo decorrido por cada carrinho, no seu deslocamento? (T.32).

2 - Deve-se medir apenas o tempo total ou o tempo antes e depois do choque? (T.34, T48, T.40).

3 - O procedimento deve estar claro para todos os participantes do grupo. (T.39, T.40).

Observa-se também que a organização do plano de trabalho é realizada na prática. A idéia já estava posta (um carrinho fica parado e o outro é lançado), mas questões práticas, como quem mede o que e como estas medidas são realizadas são aprendidas na própria execução do plano. 
Isto se verifica em T.29, quando o carrinho é lançado e só depois se define quem vai medir o que (T.31).

Uma aluna (Patrícia) tem clareza de planos de trabalho, o que não acontece com todos, pois Carla (T.33) e Marcela (T.39) aprendem no processo, que devem medir o tempo que um carrinho leva para percorre certa distância, antes e depois do choque.

Neste episódio, os alunos realizam o procedimento (deixar um carrinho parado e lançar o outro em sua direção) três vezes.

Estas repetições são necessárias, pois a cada vez que isto acontece, eles aprendem alguma coisa.

\section{Análise de dados}

A- Indicadores de desenvolvimento experimental.

No episódio anterior, o plano de trabalho foi discutido e houve uma reformulação deste plano. Neste episódio, o novo plano é colocado em prática.

Tanto no episódio anterior, quanto neste, os alunos têm a oportunidade de trocar idéias entre si e decidir os rumos da atividade (Duschl e Osborne, 2002).

Neste episódio, esta troca de idéias acontece na organização do grupo para colocar em prática o novo plano de trabalho.

Desta forma, os alunos estão desenvolvendo a habilidade de resolver problemas experimentais, o que deve ser um dos objetivos das atividades experimentais, segundo Lunetta et al., (2007).

Segundo Pizzini et. al. (1989), enquanto os alunos colocam em prática um plano de trabalho, eles estão na fase de resolver um problema experimental. Como este plano é proposto e reformulado por eles mesmos, eles estão desenvolvendo habilidades cognitivas que não desenvolveriam se a atividade fosse fechada, ou seja, se os estudantes simplesmente seguissem um roteiro pré-estabelecido pelo professor (Gil e Castro, 1996). 
Segundo nossa análise, o fato de os alunos serem capazes de colocar em prática um plano de trabalho elaborado e reformulado por eles é um indicador de desenvolvimento experimental.

B - Indicadores de envolvimento com a atividade

Em todas as falas gravadas notamos a participação dos alunos na atividade, não percebendo conversas paralelas o que é um indicador de envolvimento da atividade, segundo Freitas da Silva (2008).

Notamos também expressões de satisfação (T.42), motivados pelo fato de os alunos conseguirem uma situação na qual eles podem obter os dados, vencendo uma etapa importante do problema experimental.

Estas expressões de satisfação decorrentes de parte da resolução da atividade estão de acordo com as observações de Guridi e Islãs (2003), segundo as quais, a motivação dos estudantes é maior numa atividade aberta do que numa atividade fechada.

Estas expressões de satisfação também são indicadoras de envolvimento dos alunos com a atividade, segundo Freitas da Silva (2008).

Neste episódio, para que se chegasse a uma situação favorável à obtenção de dados, os alunos tiveram que repetir o choque entre os carrinhos algumas vezes, e no final, ao invés de ficarem chateados com isso, comemoraram (T.42). Esta comemoração é visível por suas expressões de satisfação, como mostram as fotos abaixo.

O fato deles se disporem a repetir parte do experimento a fim de melhorá-lo, condição típica do trabalho dos cientistas é um indicador de envolvimento dos estudantes, segundo nossa análise.

No trabalho dos cientistas, refazer parte de um experimento é um processo que faz parte do seu trabalho. Se os alunos assim o fazem por conta própria e se mostram satisfeitos com isso, eles estão não só "fazendo lição", mas também, "fazendo ciências" (Jiménez et. al., 2000). 

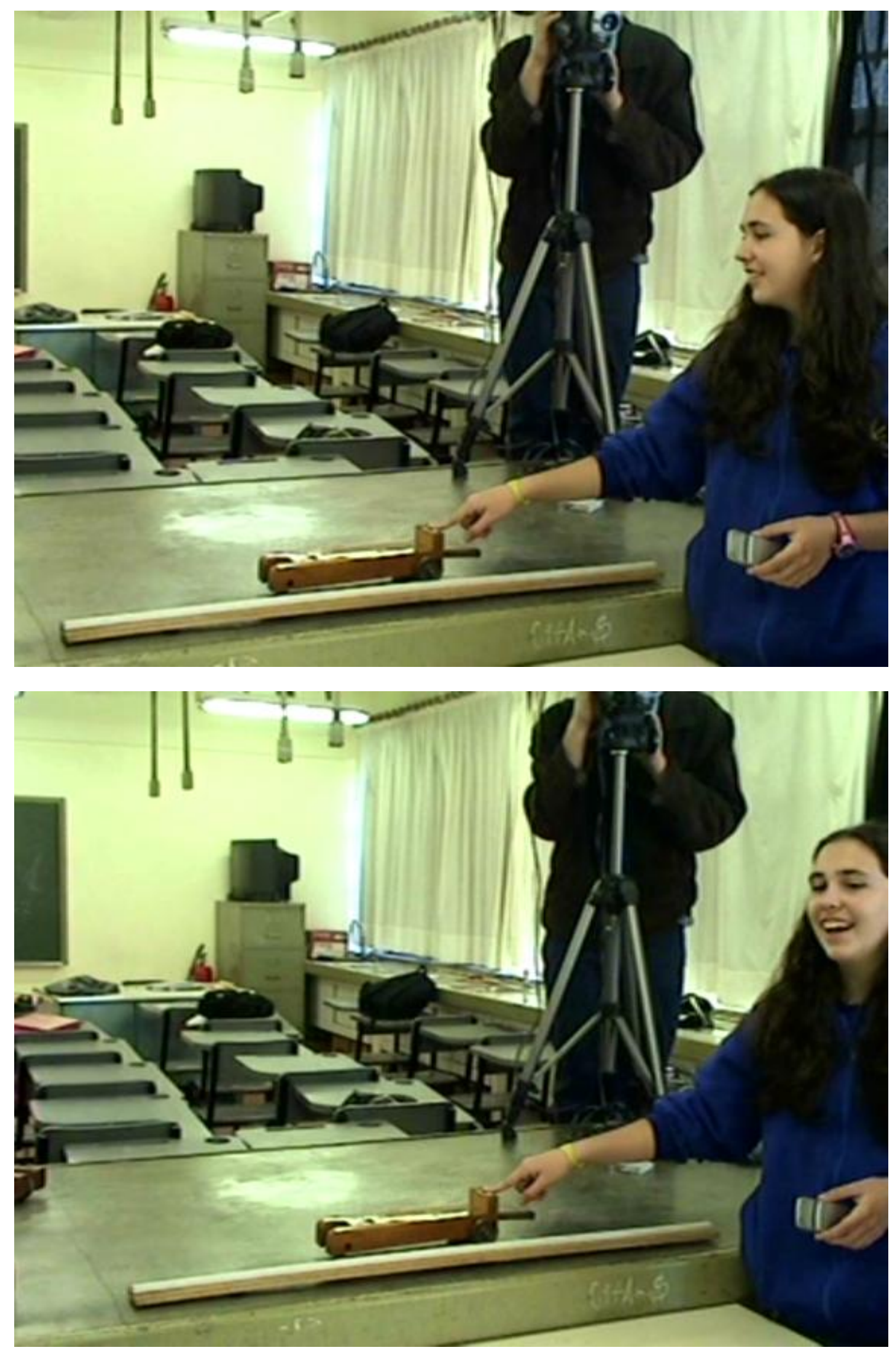


\subsubsection{Análise do Episódio 7}

Tomada de dados

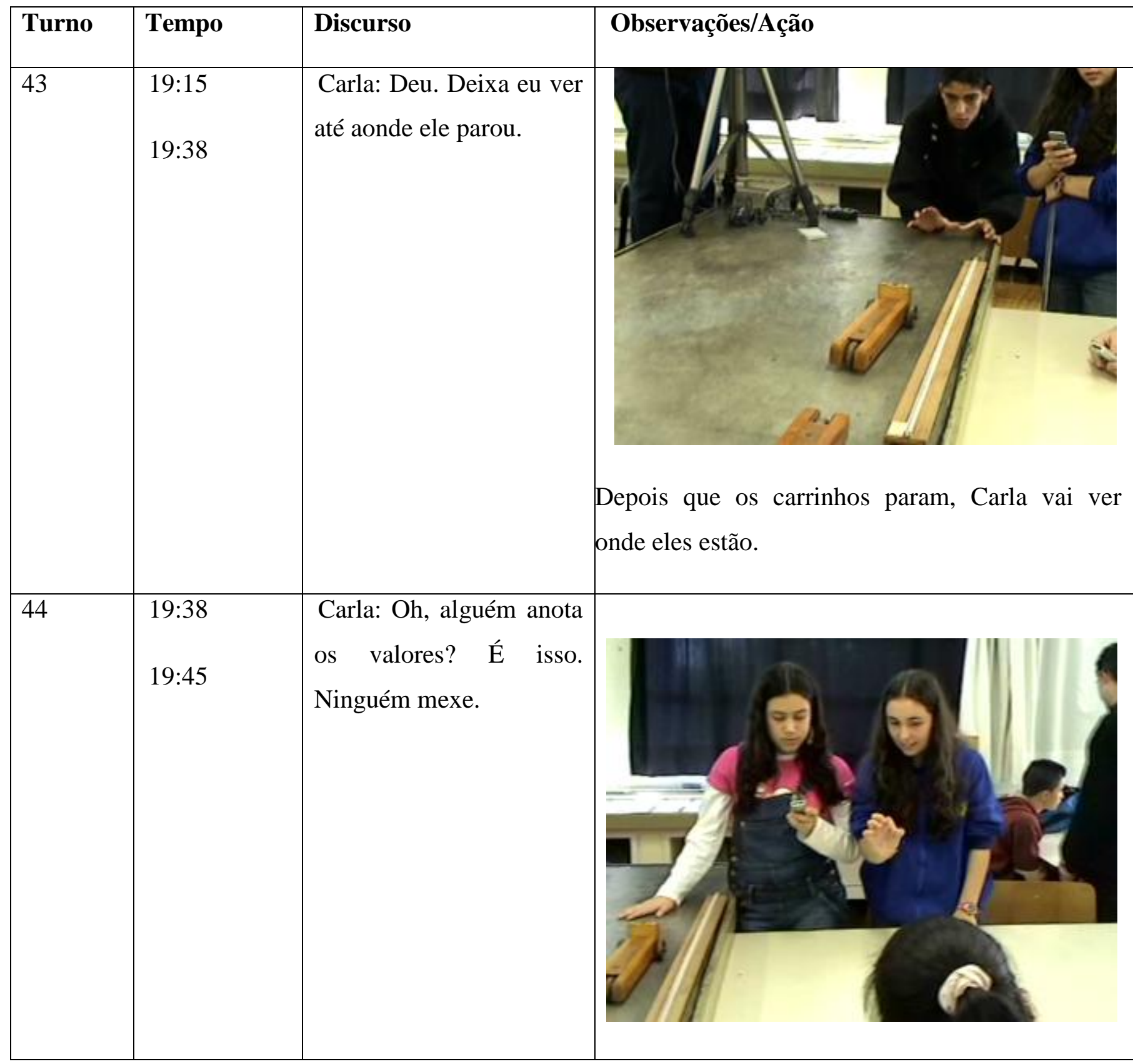




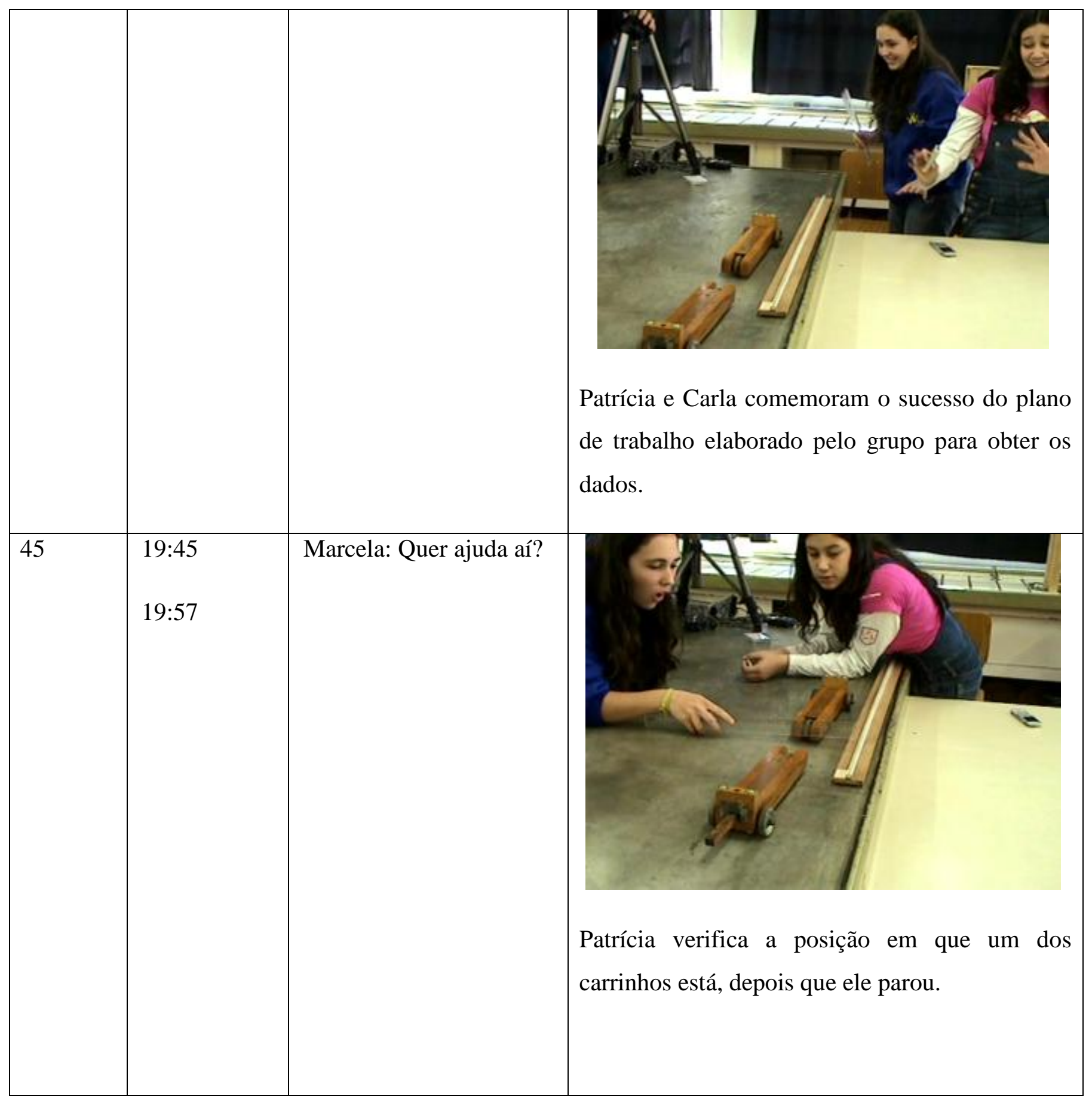




\begin{tabular}{|c|c|c|c|}
\hline 46 & $\begin{array}{l}20: 12 \\
20: 15\end{array}$ & $\begin{array}{l}\text { Carla: dá um lápis aí. } \\
\text { Espera aí. }\end{array}$ & Patrícia verifica a posição em que um dos \\
\hline 47 & $\begin{array}{l}20: 12 \\
20: 14\end{array}$ & $\begin{array}{l}\text { Patrícia: Carol escreve: } \\
\text { carrinho1 e carrinho } 2 .\end{array}$ & \\
\hline 48 & $\begin{array}{l}20: 15 \\
20: 25\end{array}$ & $\begin{array}{l}\text { Carla: Dá um lápis aqui, } \\
\text { Carol }\end{array}$ & 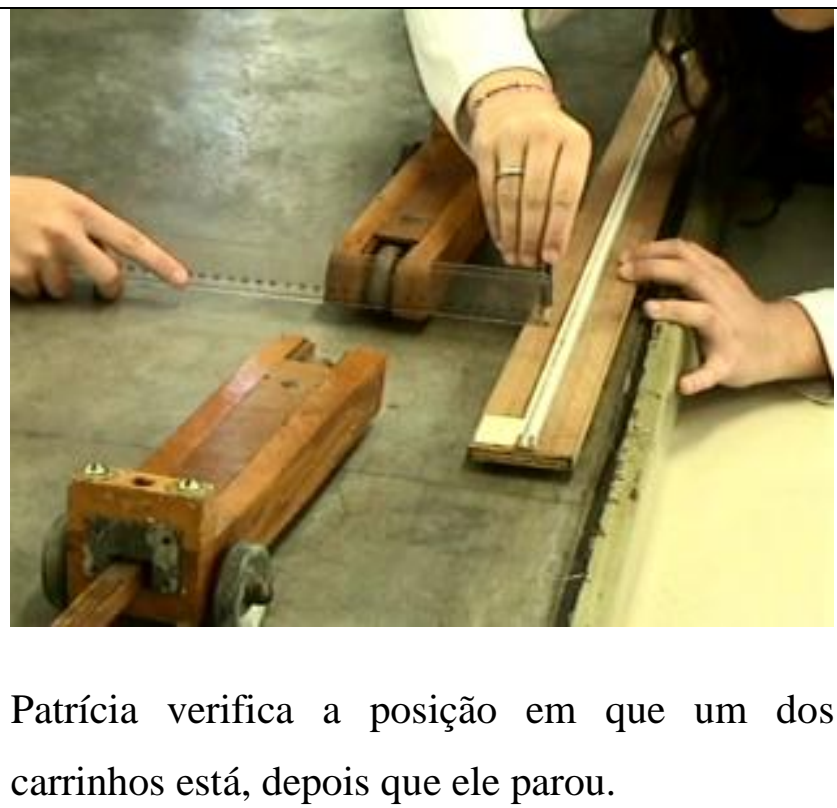 \\
\hline 49 & $\begin{array}{l}20: 25 \\
20: 39\end{array}$ & $\begin{array}{l}\text { Patrícia: agora, vou ditar: } \\
\text { põe carrinho } 1 .\end{array}$ & \\
\hline
\end{tabular}




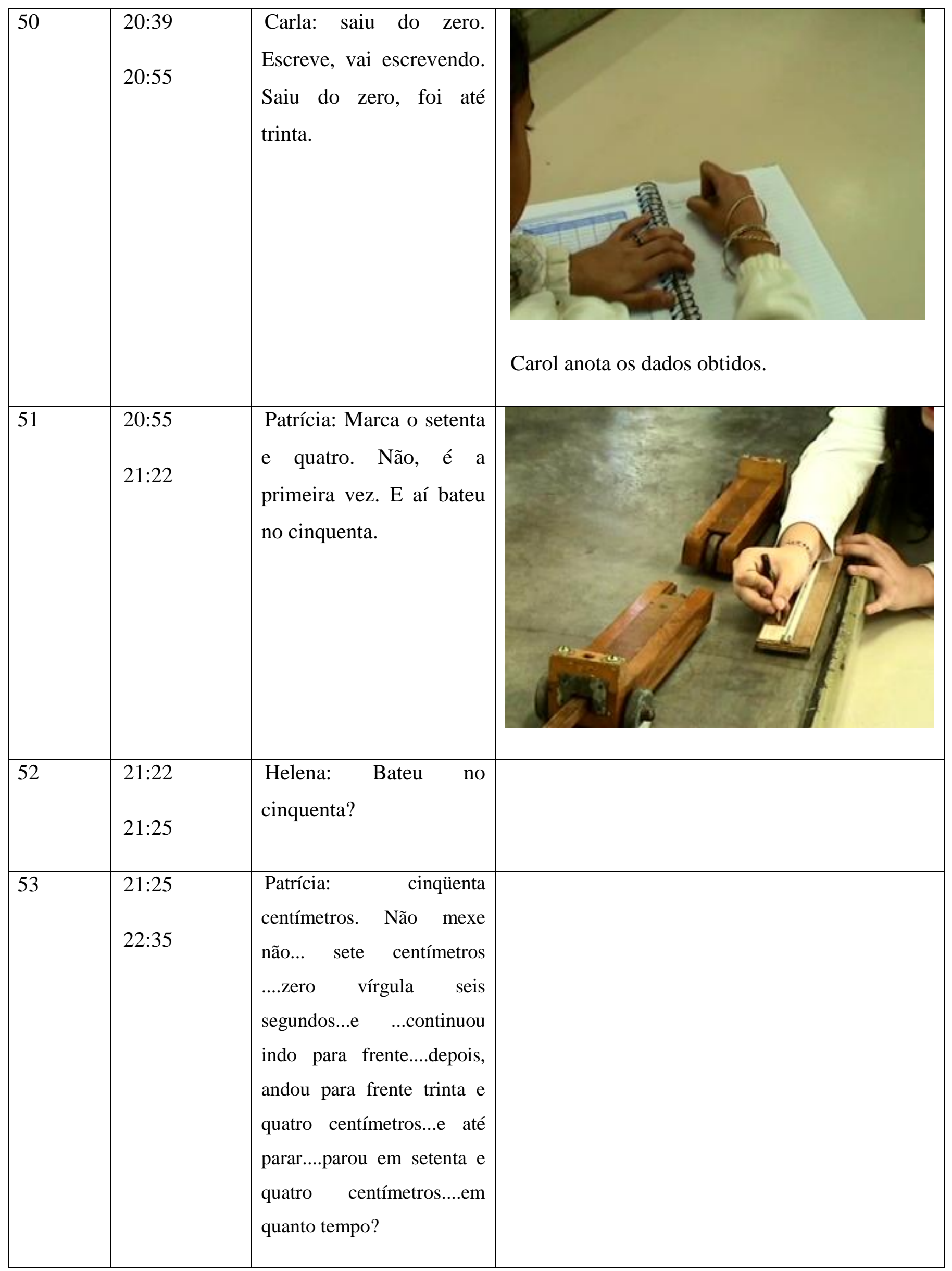




\begin{tabular}{|l|l|l|l|}
\hline 54 & $\begin{array}{l}\text { Marcela: zero vírgula } \\
\text { quatro segundos. }\end{array}$ & $\begin{array}{l}\text { Patrícia: zero vírgula } \\
\text { quatro segundos. ...é zero } \\
\text { vírgula quatro só... } \\
\text { Estava } \\
\text { cinqüenta centímetros....e } \\
\text { depois que bateu....trinta } \\
\text { e parado...a } \\
\text { centímetros....Depois que } \\
\text { bateu foi até oitenta e } \\
\text { nove...em um segundo } \\
\text { vírgula noventa e dois.... }\end{array}$ \\
\hline
\end{tabular}

\section{Comentários}

Neste episódio, os alunos têm um plano de trabalho organizado e factível com os recursos à disposição, o que permite que eles consigam fazer medições e tomar os dados necessários para a resolução do problema.

Os alunos conseguem obter um choque frontal entre os dois carrinhos, têm os tempos decorridos no movimento de cada carrinho, antes e depois do choque e estão medindo as posições em que os carrinhos param, para obter os seus deslocamentos.

Com estes deslocamentos e os tempos decorridos, eles podem medir as velocidades, antes e depois do choque.

Com os dados das velocidades e das massas dos carrinhos, os alunos podem verificar se a quantidade de movimento do sistema é a mesma, antes e depois do choque.

\section{Análise de dados}

A- Indicadores de desenvolvimento experimental. 
Lunetta et al. (2007), analisando a postura dos alunos durante uma atividade didática experimental fechada, notam uma grande preocupação por parte dos alunos em chegar a uma "resposta correta", o que não se percebe neste episódio.

Não se percebe aqui também o que Mattews (1994) apud Lunetta (2007) conclui, ou seja, que os alunos acreditam que só existe uma única resposta certa numa atividade experimental.

Aqui o que se percebe é o objetivo dos alunos de se conseguir uma forma de se obter os dados necessários, ou seja, este é o problema que se apresenta a eles e eles estão procurando resolvê-lo. Com estes dados, eles podem testar a hipótese da conservação da quantidade de movimento do sistema, antes e depois do choque.

Com este objetivo em mente por parte dos estudantes, percebemos a colaboração entre eles (T.45) e o grupo se transforma numa pequena comunidade cooperativa de aprendizagem (Lunetta et al., 2007).

Neste episódio, os alunos conseguem fazer com que o seu plano de trabalho para obter os dados se coroe de êxito.

Segundo a nossa análise, a capacidade de obter os dados necessários para se testar uma hipótese é um indicador de desenvolvimento experimental

B- Indicadores de envolvimento com a atividade.

Neste episódio, depois de diversas tentativas, da elaboração e reformulação de um plano de trabalho, os alunos conseguem deter os dados necessários para a resolução do problema. Assim, há várias expressões de satisfação por parte dos alunos. Este indicador de envolvimento com a atividade está presente.

Não percebemos conversas paralelas neste episódio, o que é um indicador de envolvimento dos alunos com a atividade, segundo Freitas da Silva (2008). 
ETAPA 2 - Aula 2 (exposição do grupo para a classe)

\subsubsection{Análise do Episódio 8}

\section{Orientação da apresentação pelo professor}

\begin{tabular}{|l|l|l|}
\hline Turno & Tempo & Discurso \\
\hline 1 & $01: 38$ & $\begin{array}{l}\text { Professor: No comecinho dessa } \\
\text { aula, nós pedimos para que } \\
\text { vocês } \text { pensassem num } \\
\text { experimento, desde a elaboração } \\
\text { dele, da idéia, tal, que vocês } \\
\text { tentassem constatar se havia ou } \\
\text { não conservação da quantidade } \\
\text { de movimento. Pra isso, vocês } \\
\text { devem ter discutido um } \\
\text { pouquinho sobre a conservação } \\
\text { da quantidade de movimento, e } \\
\text { quais as condições que elas se } \\
\text { conservam ou não. Certo? E aí, } \\
\text { vocês tiveram que bolar o } \\
\text { experimento. E a gente vai fazer } \\
\text { uma primeira rodada e os grupos } \\
\text { vão apresentar para a classe, } \\
\text { qual a idéia que vocês tiveram e } \\
\text { o que vocês anotaram. Tá? } \\
\text { Depois a gente abre para a } \\
\text { discussão de cada um deles. } \\
\text { Tudo bem? Pode começar } \\
\text { Débora. }\end{array}$ \\
\hline
\end{tabular}




\section{Comentários}

Neste episódio, o professor orienta os estudantes de como vai ser a exposição do experimento pelos grupos. Primeiramente, cada grupo fala o que fez para que depois, haja uma discussão com a classe. O que foi verificado é que só houve tempo de cada grupo expor o seu trabalho, sem ter sido possível uma discussão mais aprofundada com a classe.

G- As ações do professor.

O professor deu orientações de como vai ser a apresentação dos trabalhos.

As ações do professor segundo Penick et al. (1996), durante uma atividade experimental ou durante a sua discussão podem levar os estudantes a tomar consciência de alguns elementos do seu trabalho.

No inicio do episódio (T.1) o professor pede para que o grupo descreva o que fez para classe e é isto o que os alunos fazem.

Segundo a classificação de Penick et al (1996), esta ação remete os alunos a tomar consciência da história do experimento.

\subsubsection{Análise do Episódio 9}

Primeira tentativa de exposição

\begin{tabular}{|l|l|l|l|l|}
\hline Turno & Tempo & Discurso & Observações/Ação \\
\hline 2 & $16: 48$ & Patrícia: Então, a gente deixou \\
um carrinho parado a 50 \\
centímetros do outro...
\end{tabular}




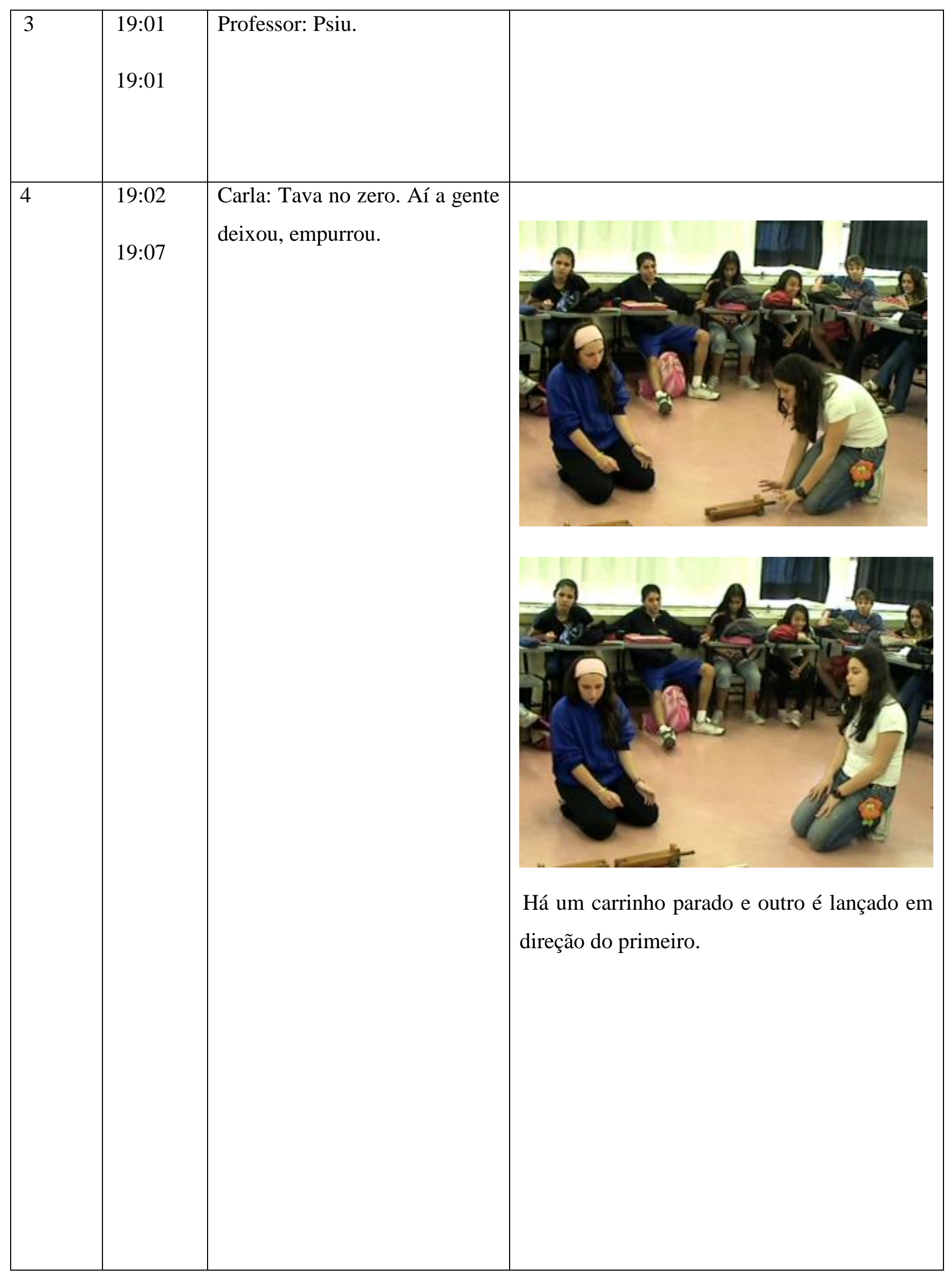




\begin{tabular}{|c|c|c|c|}
\hline 5 & $\begin{array}{l}19: 08 \\
19: 13\end{array}$ & $\begin{array}{l}\text { Carla: Aí, a gente viu a hora } \\
\text { em que ele bateu e a hora que } \\
\text { ele parou }\end{array}$ & $\begin{array}{l}\text { Foram verificados os instantes em que houve } \\
\text { pararam. }\end{array}$ \\
\hline 6 & $\begin{array}{l}19: 14 \\
19: 24\end{array}$ & $\begin{array}{l}\text { Patrícia: Então, a gente } \\
\text { cronometrou o tempo. Quanto } \\
\text { tempo demorava pra esse } \\
\text { carrinho chegar até bater e } \\
\text { quanto tempo demorou para os } \\
\text { dois pararem. }\end{array}$ & Os alunos mediram três intervalos de tempo. \\
\hline
\end{tabular}




\begin{tabular}{|l|l|l|l|}
\hline $19: 25$ & $\begin{array}{l}\text { Patrícia: Desse parar e esse } \\
\text { parar. Então, a } \text { gente } \\
\text { Cronometrou } \quad \text { esses três } \\
\text { tempos. E também mediu qual } \\
\text { foi a distância que eles que eles } \\
\text { se deslocaram depois da batida. } \\
\text { Aí a gente calculou qual era a } \\
\text { velocidade por segundo que } \\
\text { cada um estava antes e depois } \\
\text { da batida e calculou o peso de } \\
\text { cada um, a massa dois } \\
\text { carrinhos e vimos a quantidade } \\
\text { de movimento dos dois }\end{array}$ & $\begin{array}{l}\text { Foram medidas as distâncias e calculadas as } \\
\text { carrinhos, antes e depois da } \\
\text { batida. }\end{array}$ & $\begin{array}{l}\text { depois da batida. } \\
\text { Foi medida a massa de cada carrinho. }\end{array}$ \\
Foi calculada a quantidade de movimento do \\
sistema, antes e depois da batida.
\end{tabular}

\section{Comentários}

Neste episódio, os alunos procuram descrever o que aconteceu, durante o experimento.

\section{Análise de Dados}

E- A argumentação dos Alunos

Carvalho et al. (1998) dividem a exposição dos alunos a respeito de um experimento realizado por eles em duas fases: a fase do "como" e a fase do "porque". $\mathrm{Na}$ primeira fase, os alunos descrevem o experimento e na segunda, eles procuram explicar o que aconteceu.

Neste episódio, os alunos estão na fase do "como", ou seja, estão descrevendo o procedimento elaborado por eles e o que acontece nesta situação. 
Na perspectiva do modelo de Toulmin (1958), podemos dizer que a descrição do experimento são os dados que vão amparar uma reivindicação por parte dos alunos.

Parafraseando as falas de Patrícia (T.2, T.4, T.6, T.7), nós temos a seguinte descrição do experimento:

... A gente deixou um carrinho parado a $50 \mathrm{~cm}$ do outro... Ele estava no zero, $<\mathbf{e}>$ a gente o empurrou... $<\mathbf{e}>$ a gente viu a hora que ele parou... então a gente cronometrou o tempo, quanto tempo demorou para este carrinho bater e quanto tempo demorou para os dois pararem... e também mediu a distância que os dois se deslocaram após a batida <então> a gente calculou a velocidade que cada um estava, antes e depois da batida, $<$ e $>$ calculou o peso e viu a quantidade de movimento dos dois, antes e depois da batida.

Analisando a fala de Patrícia, segundo o modelo de Lawson, ainda não vemos o termo < portanto >, ou seja, não há ainda uma conclusão, o que é compatível da fase do "como", da descrição do experimento.

O termo $<\mathbf{e}>$ aparece diversas vezes, pois há diversos procedimentos adotados que se adicionam para formar a descrição do experimento.

O termo <então> aparece ligando as medidas realizadas com o cálculo da velocidade. Este cálculo é uma conseqüência das medidas realizadas anteriormente.

F- O entendimento dos conceitos envolvidos.

Os estudantes aplicaram, neste episódio, o conceito de velocidade média .

T.7- Patrícia: Desse parar e esse parar. A gente cronometrou esses dois tempos. E também mediu qual foi a distância que eles mexeram, que eles se deslocaram depois da batida, né. Aí a gente calculou qual era a velocidade, velocidade por segundo que cada um tava, que cada um tava, antes e depois da batida e depois calculou o peso, juntando a massa dos dois carrinhos e viu a quantidade de movimento dos dois, antes e depois da batida.

G- As ações do professor.

A única intervenção do professor, neste episódio, foi para pedir silêncio para a classe. 


\subsubsection{Análise do Episódio 10}

\section{Aperfeiçoamento da exposição}

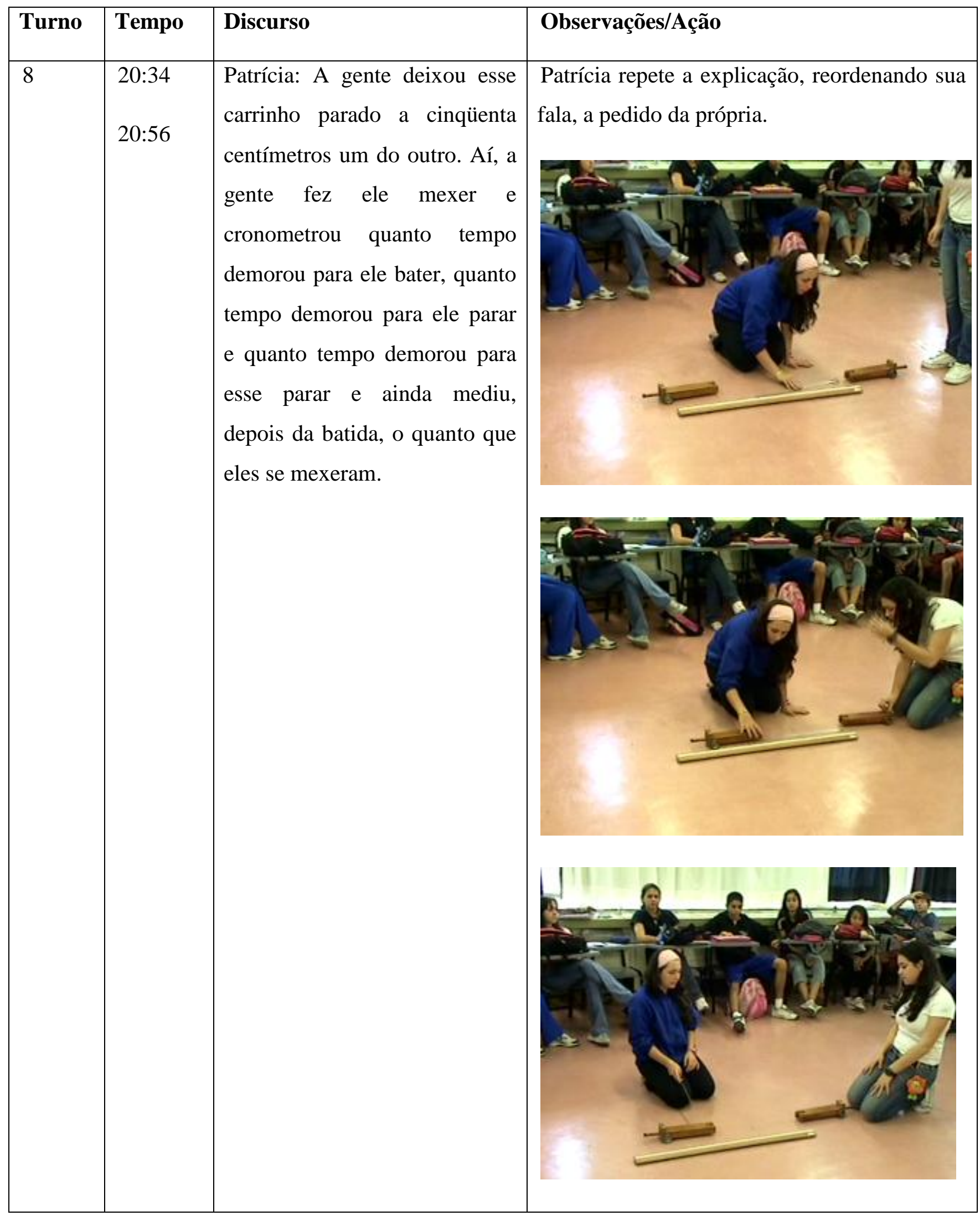




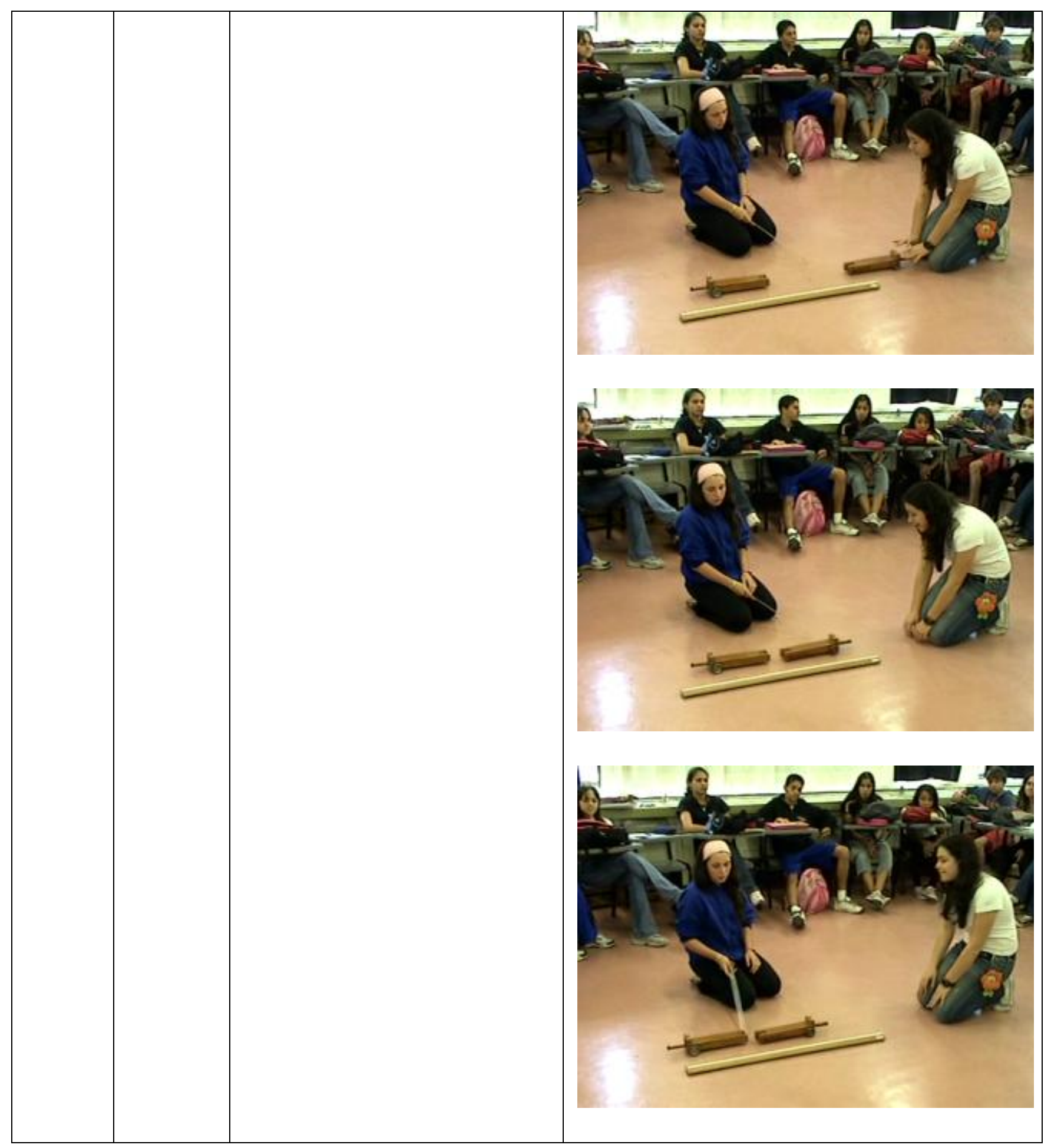




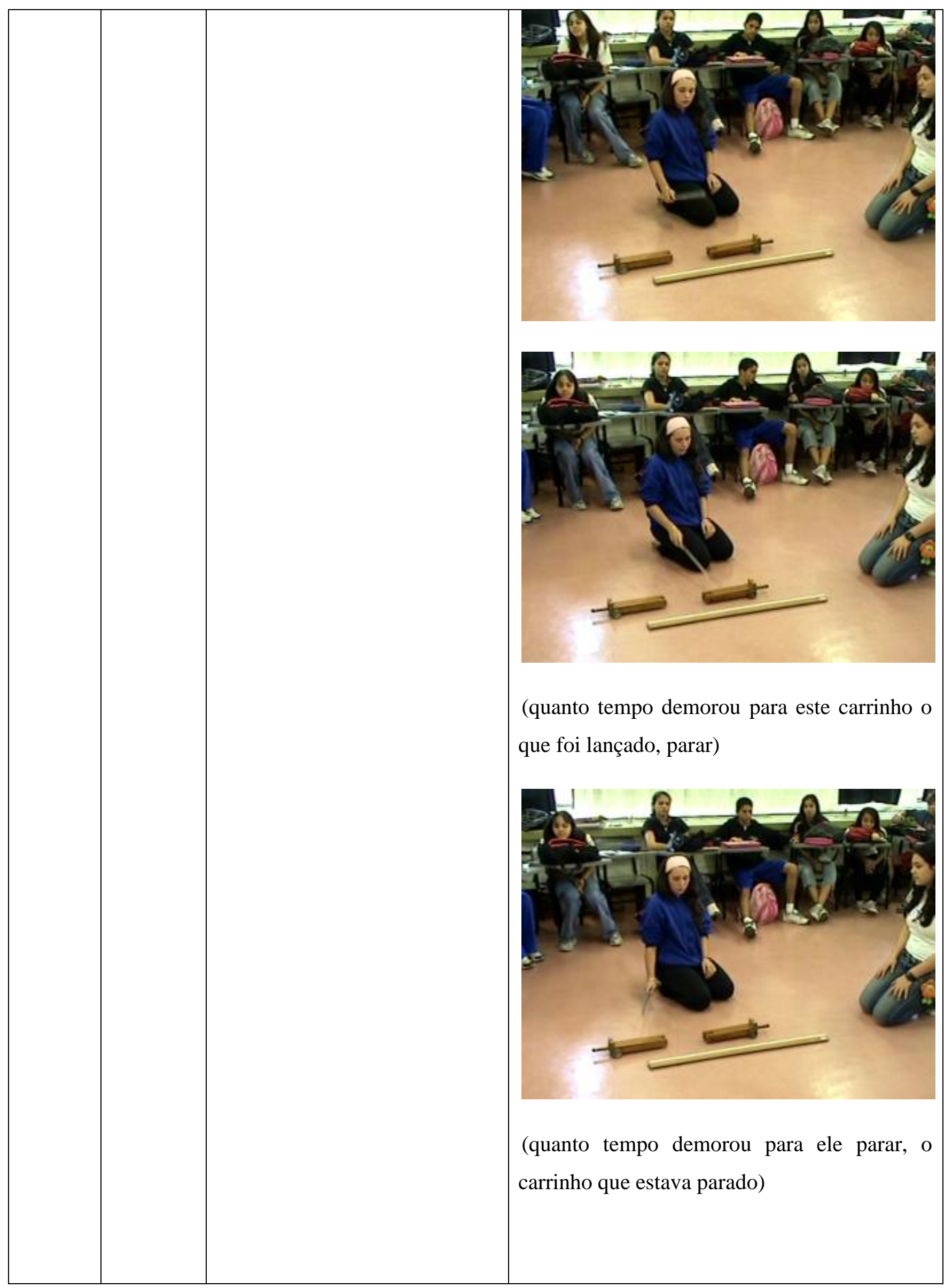




\begin{tabular}{|l|l|l|l|}
\hline 9 & $20: 57$ & $\begin{array}{l}\text { Carla: A gente mediu a massa } \\
\text { dos dois. }\end{array}$ & \\
\hline 10 & $20: 58$ & $\begin{array}{l}\text { Patrícia }: \text { E calculando assim, } \\
\text { qual é a quantidade de } \\
\text { segundos que eles estavam } \\
\text { antes e depois que houve a } \\
\text { colisão e a massa dos dois, a } \\
\text { quantidade de movimento que } \\
\text { eles estavam antes e depois. } \\
\text { Foi isso que a gente mediu. }\end{array}$ \\
\hline
\end{tabular}

\section{Comentários}

Neste episódio, os alunos repetem a descrição do experimento realizado, agora com mais detalhes e de maneira mais ordenada. Percebemos assim a importância de os alunos falarem o que fizeram e o que entenderam, pois à medida que eles falam, eles se ouvem e vão ordenando o seu conhecimento.

E- A argumentação dos Alunos

Os alunos estão descrevendo o experimento, sem tentar chegar a alguma conclusão, logo não aparece aqui a estrutura de pensamento de Lawson.

F- O entendimento dos conceitos envolvidos.

Os estudantes aplicaram, neste episódio, o conceito de velocidade média (T.8).

O conceito de quantidade de movimento e a sua conservação aparece nas falas das alunas, ainda que de uma maneira não muito bem ordenada (T.9) e (T.10).

G- As ações do professor.

Não aconteceram intervenções do professor neste episódio. 


\subsubsection{Análise do Episódio 11}

\section{Ordenação das falas dos alunos}

\begin{tabular}{|c|c|c|c|}
\hline Turno & Tempo & Discurso & Observações/Ação \\
\hline 11 & $\begin{array}{l}21: 16 \\
21: 19\end{array}$ & $\begin{array}{l}\text { Professor: Primeiro um estava } \\
\text { parado e o outro estava em } \\
\text { movimento. }\end{array}$ & $\begin{array}{l}\text { O professor procura ordenar a } \\
\text { explicação. }\end{array}$ \\
\hline 12 & $\begin{array}{l}21: 20 \\
21: 21\end{array}$ & Carla: É. & \\
\hline 13 & $\begin{array}{l}21: 21 \\
21: 23\end{array}$ & $\begin{array}{l}\text { Professor: Tá. Ai, vocês } \\
\text { mediram a velocidade do } \\
\text { primeiro carrinho. }\end{array}$ & \\
\hline 14 & $\begin{array}{l}21: 24 \\
21: 25\end{array}$ & $\begin{array}{l}\text { Carla: A gente só mediu de } \\
\text { um. }\end{array}$ & \\
\hline 15 & $\begin{array}{l}21: 26 \\
21: 27\end{array}$ & $\begin{array}{l}\text { Professor: Só desse carrinho } \\
\text { não é isso? }\end{array}$ & \\
\hline 16 & $\begin{array}{l}21: 27 \\
21: 28\end{array}$ & $\begin{array}{l}\text { Patrícia: } \mathrm{O} \text { outro estava } \\
\text { parado. }\end{array}$ & \\
\hline 17 & $\begin{array}{l}21: 29 \\
21: 30\end{array}$ & $\begin{array}{l}\text { Professor: Depois vocês } \\
\text { mediram até os dois pararem? }\end{array}$ & \\
\hline 18 & $\begin{array}{l}21: 31 \\
21: 32\end{array}$ & Carla: Não, assim... & \\
\hline 19 & $\begin{array}{l}21: 32 \\
21: 41\end{array}$ & $\begin{array}{l}\text { Patrícia: Mediu a velocidade } \\
\text { que eles estavam, gente } \\
\text { cronometrou quanto tempo } \\
\text { demorou para eles pararem, }\end{array}$ & \\
\hline
\end{tabular}




\begin{tabular}{|c|c|c|c|}
\hline & & $\begin{array}{l}\text { para saber, para calcular a } \\
\text { velocidade deles. }\end{array}$ & \\
\hline 20 & $\begin{array}{l}21: 42 \\
21: 45\end{array}$ & $\begin{array}{l}\text { Professor: Mas, aí, quando } \\
\text { eles pararam, a velocidade não } \\
\text { era zero? }\end{array}$ & $\begin{array}{l}\text { O professor procura ordenar a as } \\
\text { falas dos alunos, chamando a } \\
\text { atenção para o fato da velocidade } \\
\text { final dos carrinhos serem zero, ou } \\
\text { seja, para o fato dos alunos terem } \\
\text { medido a velocidade média e não } \\
\text { a velocidade de cada carrinho no } \\
\text { instante da batida }\end{array}$ \\
\hline 21 & $\begin{array}{l}21: 46 \\
21: 56\end{array}$ & $\begin{array}{l}\text { Patrícia: Não, sim, mas ai a } \\
\text { gente calculou quanto } \\
\text { centímetros por segundo eles } \\
\text { estavam, entendeu? Para saber } \\
\text { a velocidade. Quanto eles se } \\
\text { mexeram em tantos segundos. }\end{array}$ & \\
\hline 22 & $\begin{array}{l}21: 57 \\
22: 05\end{array}$ & $\begin{array}{l}\text { Professor: Tá. O que eu não } \\
\text { estou entendendo muito bem, } \\
\text { na verdade não to querendo } \\
\text { falar, mas, porque que vocês } \\
\text { mediram até que depois que os } \\
\text { dois parassem? }\end{array}$ & \\
\hline 23 & $\begin{array}{l}22: 06 \\
22: 13\end{array}$ & $\begin{array}{l}\text { Patrícia: Pra ver qual era a } \\
\text { distância que eles mexeram. } \\
\text { Pra calcular, depois qual era a } \\
\text { velocidade que eles estavam } \\
\text { depois da batida. }\end{array}$ & \\
\hline 24 & $\begin{array}{l}22: 14 \\
22: 15\end{array}$ & $\begin{array}{l}\text { Professor: Não, mas, se eles } \\
\text { pararam, a velocidade depois } \\
\text { não era zero? }\end{array}$ & \\
\hline
\end{tabular}




\begin{tabular}{|c|c|c|c|}
\hline 25 & $\begin{array}{l}22: 16 \\
22: 21\end{array}$ & $\begin{array}{l}\text { Patrícia: Sim professor, mas é } \\
\text { assim: a gente calculou quanto } \\
\text { tempo demorou pra eles } \\
\text { percorrerem esse caminho. }\end{array}$ & \\
\hline 26 & $\begin{array}{l}22: 22 \\
22: 23\end{array}$ & $\begin{array}{l}\text { Professor: Calcular a } \\
\text { velocidade média. }\end{array}$ & \\
\hline 27 & $\begin{array}{l}22: 24 \\
22: 25\end{array}$ & $\begin{array}{l}\text { Patrícia: É, calculou a } \\
\text { velocidade que ele estava. }\end{array}$ & Velocidade média \\
\hline 28 & $\begin{array}{l}22: 26 \\
22: 27\end{array}$ & $\begin{array}{l}\text { Professor: O tempo que eles } \\
\text { demoraram até parar? }\end{array}$ & \\
\hline 29 & $\begin{array}{l}22: 27 \\
22: 34\end{array}$ & $\begin{array}{l}\text { Patrícia: É, demorou zero } \\
\text { vírgula qualquer coisa para ele } \\
\text { parar. A gente viu o quanto que } \\
\text { ele mexeu, então, quantos } \\
\text { centímetros num segundo ele } \\
\text { andaria. }\end{array}$ & $\begin{array}{l}\text { 〈se〉 este aqui demorou zero } \\
\text { vírgula qualquer coisa para ele } \\
\text { parar 〈e〉a gente viu o quanto que } \\
\text { ele mexeu, então, (podemos } \\
\text { calcular sua velocidade) quantos } \\
\text { centímetros em um segundo, } \\
\text { quanto tempo ele varia, nos dois } \\
\text { casos. }\end{array}$ \\
\hline 30 & $\begin{array}{l}22: 35 \\
22: 36\end{array}$ & $\begin{array}{llll}\text { Professor: } & \text { Para } & \text { os } & \text { dois } \\
\text { carrinhos? } & & & \\
\end{array}$ & \\
\hline 31 & $\begin{array}{l}22: 36 \\
22: 37\end{array}$ & Patrícia: Nos dois carrinhos. & \\
\hline
\end{tabular}

\section{Comentários}

Neste episódio o professor procura ordenar o pensamento e a fala dos alunos, fazendo colocações com a intenção de provocar os alunos e fazê-los colocar com mais 
clareza a discussão do procedimento realizado por eles, os conceitos utilizados e as conclusões a que os estudantes chegaram.

\section{Análise de Dados.}

E- A argumentação dos alunos.

A estrutura de raciocínio proposta por Lawson (2000) está presente parcialmente no turno 29. “〈se〉 este aqui demorou dez vírgula qualquer coisa para ele parar 〈e〉 a gente viu o quanto que ele mexeu, então, (podemos calcular sua velocidade) quantos centímetros em um segundo, quanto tempo ele varia, nos dois casos."

Parafraseando a fala desta aluna, temos:

〈Se〉 este aqui demorou dez vírgula qualquer coisa para ele parar (medimos $e$ tempo que o carrinho demorou até parar) 〈e〉 a gente viu o quanto que ele mexeu (medimos a distância percorrida por ele) então, (podemos calcular sua velocidade) quantos centímetros em um segundo, quanto tempo ele varia, nos dois casos.

F- O entendimento conceitual dos alunos

O desenvolvimento conceitual por parte dos alunos é um dos objetivos de uma atividade experimental (Driver et al., 2000) e neste episódio, os professor procura verificar se os alunos conseguem diferenciar os conceitos de velocidade média e velocidade instantânea (T.20, T.22, T.24, T.26), porem não se nota esta diferença na fala dos alunos, pois eles apenas usam o termo velocidade, como uma relação entre distância percorrida e tempo decorrido (T.26, T.28, T.30, T.32).

Percebemos nestas falas o entendimento dos alunos de que para se determinar a velocidade de um corpo deve-se medir a distância percorrida por ele num determinado tempo, mas não se percebe o entendimento dos conceitos de velocidade média e instantânea.

Percebemos sim, uma confusão ente estes dois conceitos, pois os alunos medem a distância percorrida pelos carrinhos até que eles parem e o tempo que isto levou e calculam o que seria a velocidade de cada carrinho após o choque (T25, T.27). 
$\mathrm{G}-$ As ações do professor

Inicialmente, o professor procura resgatar o que os alunos fizeram e o que aconteceu durante o experimento (T.11, T.13, T.25, T.17), o que na classificação de Penick et al. (1996) significa que com esta ação, o professor quer que os alunos tomem consciência da história do experimento.

Nos turnos seguintes (T.20, T.22, T.24, T.26) a atenção do professor se volta para a concepção que os alunos têm do conceito de velocidade, procurando fazer com que os alunos tomem consciência da diferença entre velocidade instantânea e velocidade média.

Com isso, o professor quer que os alunos relacionem os dados detidos e os procedimentos adotados com os conceitos de velocidade média e velocidade instantânea.

Nesta fala (T.22), o professor já não está interessado na descrição do experimento e sim nas razões que levaram os alunos a fazer o que fizeram.

Aparece, pela primeira vez, na fala do professor, a palavra "porque" ("porque que vocês mediram até que os dois parassem?"). Com esta pergunta, o professor quer que os alunos demonstrem que conceitos foram mobilizados para que os alunos tomassem a decisão de medir a distância percorrida por cada carrinho, desde o choque até a sua parada.

Segundo Penick et al. (1996), esta ação do professor tem como sentido fazer com que os alunos tomem consciência das relações existentes no experimento. 


\subsubsection{Análise do Episódio 12}

\section{Conclusão da apresentação.}

\begin{tabular}{|c|c|c|c|}
\hline Turno & Tempo & Discurso & Observações/Ação \\
\hline 32 & $\begin{array}{l}22: 38 \\
22: 39\end{array}$ & $\begin{array}{l}\text { Professor: E aí, a que conclusão vocês } \\
\text { chegaram? }\end{array}$ & 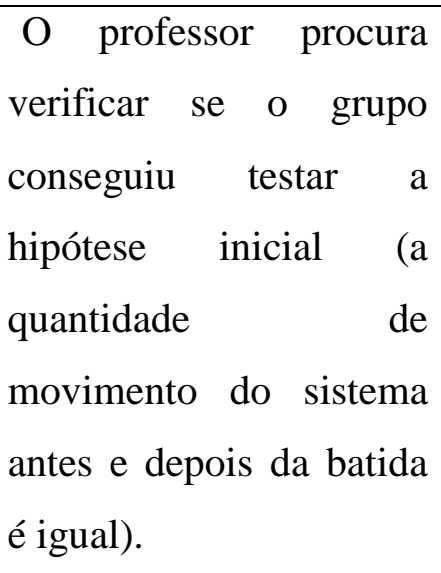 \\
\hline 33 & $\begin{array}{l}22: 40 \\
22: 51\end{array}$ & $\begin{array}{l}\text { Patrícia: Sim. O resultado que a gente } \\
\text { fez (obteve) depois da conservação } \\
\text { (batida), da quantidade de movimento, } \\
\text { antes e depois dos dois carrinhos, a } \\
\text { soma dos dois deu um pouco diferente. } \\
\text { Não era exatamente igual. A gente } \\
\text { calculou. }\end{array}$ & $\begin{array}{l}\text { A quantidade } \\
\text { movimento não } \\
\text { se } \\
\text { conserva. }\end{array}$ \\
\hline 34 & $\begin{array}{l}22: 52 \\
23: 01\end{array}$ & $\begin{array}{l}\text { Professor: Qual das duas quantidades } \\
\text { de movimento foi maior? Antes ou } \\
\text { depois? }\end{array}$ & \\
\hline 35 & $\begin{array}{l}23: 01 \\
23: 03\end{array}$ & Patrícia: A de antes foi maior. & \\
\hline 36 & $\begin{array}{l}23: 04 \\
23: 05\end{array}$ & Professor: Antes foi maior? & \\
\hline 37 & $\begin{array}{l}23: 05 \\
23: 07\end{array}$ & Patrícia: É antes foi maior. & \\
\hline
\end{tabular}




\begin{tabular}{|c|c|c|}
\hline 38 & $\begin{array}{l}23: 08 \\
23: 09\end{array}$ & Daniel: Antes foi maior. \\
\hline 39 & $\begin{array}{l}23: 09 \\
23: 10\end{array}$ & $\begin{array}{l}\text { Professor: Em todas as contas? Quantas } \\
\text { medidas vocês fizeram? }\end{array}$ \\
\hline 40 & $\begin{array}{l}23: 11 \\
23: 12\end{array}$ & Patrícia: Como é que é? \\
\hline 41 & $\begin{array}{l}23: 13 \\
23: 14\end{array}$ & Professor: Quantas medidas? \\
\hline 42 & $\begin{array}{l}23: 15 \\
23: 16\end{array}$ & $\begin{array}{l}\text { Patrícia: A gente fez uma única } \\
\text { medida, a gente fez uma vez só. }\end{array}$ \\
\hline 43 & $\begin{array}{l}23: 17 \\
23: 23\end{array}$ & $\begin{array}{l}\text { Professor: Fizeram uma única medida } \\
\text { e nessa única medida que vocês fizeram } \\
\text { né, o tempo antes. }\end{array}$ \\
\hline 44 & $\begin{array}{l}23: 23 \\
23: 24\end{array}$ & $\begin{array}{l}\text { Patrícia: A quantidade de movimento } \\
\text { era maior. }\end{array}$ \\
\hline 45 & $\begin{array}{l}23: 25 \\
23: 26\end{array}$ & $\begin{array}{l}\text { Professor: A quantidade de movimento } \\
\text { antes é maior que a quantidade de } \\
\text { movimento depois. }\end{array}$ \\
\hline 46 & $\begin{array}{l}23: 27 \\
23: 28\end{array}$ & Patrícia: (confirma com a cabeça) \\
\hline
\end{tabular}




\section{Análise de dados}

E- A argumentação dos alunos

Com este episódio se encerra a apresentação deste grupo do seu experimento e da conclusão a que os alunos chegam.

É possível, agora, com a apresentação completa do grupo, observar a estrutura de raciocínio de Lawson (se, e, mas, então, portanto).

Para apresentar esta estrutura de raciocínio, vamos parafrasear a fala dos alunos, utilizando trechos de diversos episódios, no início da sua apresentação até a conclusão.

$<$ Se> a gente deixou um carrinho parado a $50 \mathrm{~cm}$ do outro (T.2)... <e $>$ a gente empurrou (um carrinho contra o outro) (T.4)... 〈e> a gente viu a hora que ele bateu e a hora que ele parou (T.5)... <e> a gente cronometrou o tempo, quanto tempo demorava para este carrinho chegar até bater e quanto tempo demorou para os dois pararem (T.6)... <e> a gente mediu também a distância que eles se deslocaram depois da batida (T.7)... <então> a gente calculou qual era a velocidade que cada um estava antes e depois da batida e depois calculou o peso.

Juntando a massa dos dois carrinhos e viu a quantidade de movimento dos dois antes e depois da batida (T.7)... <portanto>, o resultado que a gente fez (obteve) da quantidade de movimento deu um pouco diferente (T.33)... A de antes foi maior (T.35)... A quantidade de movimento era maior (T.44).

Utilizando-se o modelo de Toulmin, podemos identificar, nesta argumentação, os elementos da estrutura de pensamento dos alunos:

- Dados: As medidas obtidas pelos alunos.

- Reivindicação: A quantidade de movimento do sistema antes do choque era maior que após o choque.

- Justificativa: os cálculos das velocidades e das quantidades de movimento e dos carrinhos, antes e depois do choque. 
- Apoios: Os conceitos de quantidade de movimento e conservação da quantidade de movimento.

Segundo o modelo de Toulmin, podemos dizer que os dados obtidos pelos estudantes, baseados no seu plano de trabalho para estudar a situação proposta por eles são justificadas pelos cálculos realizados pelos alunos para determinar as quantidades de movimento do sistema, antes e depois do choque entre os carrinhos.

Esta justificativa é apoiada pela teoria (Principio da Conservação da Quantidade de Movimento), ou pelo que os alunos entendem destes conceitos.

Esta justificativa (cálculos) baseada nos dados (dados obtidos pelos alunos baseados no seu plano de trabalho) é apoiada pelo entendimento dos alunos da teoria e permite que os alunos cheguem a seguinte reivindicação: "A quantidade de movimento do sistema era maior antes do choque do que depois".

Utilizando-se esta paráfrase, a argumentação dos alunos aparece de forma completa.

Nesta situação, utilizando-se o instrumento proposto por Driver e Newton (1997) para avaliar os argumentos dos alunos, percebemos que eles chegam ao nível 3 (Reivindicação com argumentos e qualificadores):

- Reivindicação: a quantidade de movimento do sistema era maior, antes do choque do que depois.

-Argumentação: o plano de trabalho, as medidas e os cálculos realizados pelos alunos.

-Qualificadores: o entendimento dos alunos dos conceitos a quantidade de movimento e sua conservação.

Carvalho et al.(1998) mostram quando crianças do ensino fundamental expõem um experimento realizado por eles, primeiro eles mostram "como" o experimento aconteceu, o que ocorreu e o que eles fizeram, ou seja, eles descrevem o experimento.

Passada a fase do "como", eles passam a fase do "porque", ou seja, mostram as suas conclusões com base no experimento. 
Podemos ver, nas falas dos alunos do grupo analisado, enquanto eles apresentam o seu experimento, estas duas fases: inicialmente, eles descrevem o seu plano de trabalho, os dados detidos e os cálculos realizados por eles, passando a maior parte do tempo nesta fase, a fase do "como" (T.2 a T.31). Apenas as últimas falas são dedicadas à conclusão a que o grupo chegou (T.33 a T.46).

A divisão das falas dos alunos do ensino médio na apresentação de um experimento é compatível à observada por Carvalho et al. (1998) com os alunos do ensino fundamental.

F - Análise do entendimento conceitual.

Neste episódio, os alunos mobilizam o seu entendimento da lei da conservação da quantidade de movimento.

Eles calcularam a quantidade de movimento do sistema, antes e depois do choque entre os carrinhos e concluíram que a quantidade de movimento do sistema era maior antes do choque, ou seja, que não houve conservação da quantidade de movimento (T.38, T.43, T.46).

Após este episódio, podemos mapear todos os conceitos mobilizados pelos alunos e o seu entendimento destes conceitos:

1 - Velocidade: os alunos sabem que a velocidade é uma relação entre espaço percorrido e tempo (T.7, T.13), entretanto não há a diferenciação entre os conceitos de velocidade média e instantânea, tanto que os alunos determinam a velocidade de cada carrinho após o choque medindo a distância percorrida por cada um desde o choque até sua parada e o tempo decorrido neste movimento. Em outras palavras, para eles, a velocidade de cada carrinho no instante após o choque é a sua velocidade média, do instante do choque até sua parada.

\section{2 - Quantidade de movimento}

Os alunos percebem que a quantidade de movimento de um corpo é dada pelo produto entre massa e velocidade (T.7), mas parece que o cálculo deles da quantidade de movimento do sistema foi feita somando-se a massa dos dois carrinhos e não as quantidades de movimento de cada carrinho (T.7). 


\section{3 - Conservação da Quantidade de Movimento}

Os alunos mediram a quantidade de movimento do sistema, antes e depois do choque entre os carrinhos e perceberam que a quantidade de movimento do sistema era maior antes do choque (T.40, T.42, T.43), ou seja, que a quantidade de movimento do sistema não se conserva.

Não percebemos, nas falas dos alunos nenhuma tentativa de explicação das causas deste resultado, ou seja, do porque a quantidade de movimento do sistema seria maior, antes do que depois do choque.

Notamos então a mobilização de alguns conceitos físicos para a resolução do problema proposto, mas também a existência de lacunas conceituais por parte dos alunos.

$\mathrm{G}$ - Análise das ações do professor

Neste episódio o professor procura fazer com que os alunos cheguem a alguma conclusão, baseada nas observações que eles fizeram do experimento (T.37).

Ele procura fazer com que os alunos relacionem os resultados detidos com o conceito de conservação da quantidade de movimento.

Segundo a classificação de Penick et al. (1996), o professor quer que (neste episódio) os alunos tomem consciência da relação entre o experimento realizado por eles e o Principio de Conservação de Quantidade de Movimento.

A classificação de Penick et al. (1996) para as ações do professor durante a exposição por parte dos alunos de uma atividade experimental, propõe que estas ações levem os alunos a tomar consciência de cinco elementos do seu trabalho:

1 - A história do experimento

2 - Relações

3 - Aplicações

4 - Contexto 


\section{5 - Explicações}

Segundo nossa análise, o professor, nesta atividade se concentrou nos dois primeiros elementos (a história do experimento e as relações entre o experimento e a teoria).

Em outras palavras, segundo Carvalho et al. (1998) o professor se concentra em fazer com que os alunos tomem consciência de "como" o experimento ocorreu e depois de "porque" se obteve tais resultados, ou seja, qual é a relação entre o experimento e a teoria.

Na classificação de Penick et al. (1996) existem três elementos que não aparecem como foco da atenção do professor: aplicações, especulações e contexto.

\section{Análise das fases do trabalho dos alunos.}

A nossa análise do trabalho realizado pelos alunos, desde a apresentação do problema pelo professor até o final da exposição dos estudantes, faz com que percebamos algumas fases neste trabalho.

Podemos dividir estas fases em etapas, como proposto por Pizzini et al. (1989)

1 - Pesquisar

2 - Resolver

$3-$ Criar

4 - Compartilhar

Cada etapa destas pode ainda, segundo nossa análise, ser divididas em algumas fases.

Fase 1 - Pesquisar

Nesta fase, os alunos procuram subsídios para começar o trabalho.

De início, notamos certa paralisia por parte dos alunos.

A proposta da atividade é não ter um roteiro estabelecido previamente para os alunos seguirem. Assim, de início, eles ficam sem saber o que fazer e neste momento, a 
contribuição do professor é fundamental, pois ele percebe o estado dos alunos e faz duas colocações que fazem com que os alunos comecem a desenvolver o trabalho: "aproveitem os materiais" (T.1) e "peguem a apostila" (T.1).

No grupo analisado, estas foram as únicas intervenções do professor, e foram suficientes para que os alunos realizassem todo o trabalho.

Podemos dizer que estas duas sugestões, "aproveitem os materiais" e "peguem a apostila" foram fundamentais para o início do processo.

Uma sugestão do professor, "peguem a apostila" gerou outra reação por parte dos alunos, a qual permitiu que eles saíssem do estado de paralisia. Alguns dos alunos do grupo estudado foram buscar na apostila usada nas aulas teóricas subsídios para a resolução do problema experimenta. Eles encontraram ali, um exemplo clássico de conservação da quantidade de movimento, que é o choque frontal entre dois corpos e foi este exemplo que os alunos escolheram para transformar em uma situação experimental.

\section{Etapa 2 - Resolver}

Nesta etapa, os alunos resolvem o problema proposto pelo professor.

A partir da sugestão do professor: "aproveitem os materiais" os alunos começam a "buscar" com os elementos colocados a sua disposição. No caso do grupo estudado, os alunos começam a jogar um carrinho contra o outro, de início despretensiosamente, mas aos poucos, começa a surgir um plano de trabalho.

Carvalho et al. (1998) já haviam mostrado que, quando alunos do Ensino Fundamental I, crianças entre 8 e 10 anos são colocados em contato com um desafio experimental, inicialmente, sua primeira reação também é manipular os materiais postos a sua disposição. Na nossa, pesquisa, vimos acontecer a mesma coisa com alunos do primeiro ano do ensino médio.

Da integração da manipulação dos materiais com a busca de subsídios teóricos, surge um plano de trabalho por parte dos alunos. 
Nesta fase, eles já conhecem os materiais a sua disposição, já têm subsídios teóricos para a resolução do problema e já reconhecem um exemplo teórico que pode ser colocado em prática por eles.

O que acontece agora é, a partir disto, a elaboração de um plano de trabalho para a resolução do problema proposto.

A situação explorada pelo grupo foi a seguinte:

Verificar se, num choque frontal entre dois carrinhos, a quantidade de movimento se conserva.

Para isto, os alunos percebem que eles devem determinar as massas dos carrinhos e suas velocidades, antes e depois do choque. Para tanto, eles devem medir as distâncias percorridas por cada carrinho, antes e depois do choque e o tempo que cada carrinho levou para percorrer tais distâncias.

Sabendo o que deve ser feito, os alunos se organizam, distribuindo tarefas entre si para executar o plano de trabalho elaborado.

- Alguns alunos medem as distâncias percorridas pelos carrinhos, antes e depois do choque.

- Alguns alunos medem o tempo necessário para cada carrinho percorrer as distâncias medidas, antes e depois do choque.

- Um aluno mede as massas dos carrinhos.

- Uma aluna faz as anotações necessárias.

Ao executar este plano, os alunos percebem algumas dificuldades, a saber:

- Às vezes, eles lançam os carrinhos e eles não se chocam.

- Às vezes, os carrinhos se chocam, mas o choque não é frontal.

- É difícil saber exatamente onde os carrinhos se chocam.

- É difícil medir os tempos com um cronômetro, pois o tempo decorrido antes do choque é muito pequeno. 
Estas dificuldades fazem os alunos repetir o procedimento algumas vezes até que eles resolvem alterar o plano de trabalho.

Os alunos tentaram várias vezes colocar o seu plano em prática e não conseguiram obter os dados necessários. Ao mesmo tempo, um aluno que não estava participando diretamente da execução do plano de trabalho percebe uma forma mais eficiente de colocá-lo em prática e consegue que sua idéia seja aceita.

Sua idéia é a seguinte: ao invés de dois carrinhos serem lançados um contra o outro, os alunos resolvem deixar um carrinho parado e lançar um deles contra o parado.

Ao fazem isto, eles conseguem tomar os dados necessários na primeira tentativa.

O novo plano de trabalho é um sucesso e os alunos conseguem tomar os dados necessários. Uma aluna mede a distância entre os carrinhos, e qual é a distância percorrida por um carrinho até o choque, com uma trégua.

Uma aluna mede o tempo decorrido desde o lançamento de um carrinho até o choque, com um cronômetro.

Outros alunos medem as distâncias percorridas pelos carrinhos após o choque, com uma régua.

Dois alunos medem o tempo necessário para os carrinhos percorrerem tais distâncias, com cronômetros.

A massa dos carrinhos é medida.

Com estes dados obtidos, o grupo é capaz de determinar a quantidade de movimento do sistema, antes e depois do choque e verificar se ela se conserva.

A Etapa 3 da classificação de Pizzini et al. (1989) não foi observada nesta atividade.

\section{Etapa 4 - Compartilhar}

Nesta etapa, nós observamos claramente duas fases distintas: a fase do "como" e a fase do "porque" (Carvalho et al., 1998). 
$\mathrm{Na}$ fase do "como", os alunos descrevem o que aconteceu, como já foi colocado anteriormente na nossa pesquisa.

Na fase do "porque", os alunos colocam a conclusão a que chegaram.

\section{Grupo B}

\section{ETAPA 1 - Aula 1 (exposição do grupo para a classe toda)}

Inicialmente, o professor coloca os alunos formando uma grande roda e pede para que cada grupo exponha a situação que construiu com os materiais à disposição e exponha como, na situação escolhida, os alunos verificaram se, nesta situação, a quantidade de movimento se conservou ou não.

Os alunos do grupo, ao qual chamamos de "grupo B", expõem o que fizeram, o que observaram e a que conclusão chegaram.

\subsubsection{Análise do Episódio 13}

\section{Demonstração}

\begin{tabular}{|l|l|l|l|}
\hline Turno & Tempo & Discurso & Observações/Ação \\
\hline 1 & $24: 14$ & $\begin{array}{l}\text { Carina: A gente fez a } \\
\text { experiência dos carrinhos } \\
\text { batendo na bancada com a } \\
\text { mola. }\end{array}$ & \\
\hline 2 & $24: 21$ & Professor: mostra aqui! & \\
\hline 3 & $24: 23$ & $\begin{array}{l}\text { Joana: Pode ser um só? } \\
\text { 24:24 }\end{array}$ & $\begin{array}{l}\text { Professor: Vocês usaram um } \\
\text { só? }\end{array}$ \\
\hline 4 & $24: 25$ & & \\
\hline
\end{tabular}




\begin{tabular}{|c|c|c|c|}
\hline 5 & $\begin{array}{l}24: 28 \\
24: 29\end{array}$ & $\begin{array}{l}\text { Joana: Na verdade a gente } \\
\text { acabou usando dois. }\end{array}$ & \\
\hline 6 & $\begin{array}{l}24: 30 \\
24: 35\end{array}$ & Carina: travou a mola. & Carina tenta travar a mola de um dos carrinhos. \\
\hline 7 & $\begin{array}{l}24: 36 \\
24: 37\end{array}$ & $\begin{array}{l}\text { Professor: demonstrem o que } \\
\text { vocês fizeram. }\end{array}$ & \\
\hline 8 & $\begin{array}{l}24: 38 \\
24: 40\end{array}$ & Pedro: coloque o obstáculo & $\begin{array}{l}\text { Pedro oferece um caderno à Carina para simular } \\
\text { um obstáculo. }\end{array}$ \\
\hline
\end{tabular}




\begin{tabular}{|c|c|c|c|}
\hline 9 & $\begin{array}{l}24: 41 \\
24: 52\end{array}$ & $\begin{array}{l}\text { Carina: a gente pôs dois } \\
\text { carrinhos ao mesmo tempo. } \\
\text { Só que, assim, este aqui tinha } \\
\text { mais...é maior. }\end{array}$ & Carina posiciona dois carrinhos juntos na frente \\
\hline 10 & $\begin{array}{l}24: 53 \\
24: 54\end{array}$ & $\begin{array}{l}\text { Professor: Espera aí. Um } \\
\text { estava com a mola } \\
\text { comprimida e o outro não. É } \\
\text { isso? }\end{array}$ & \\
\hline 11 & $\begin{array}{l}24: 55 \\
25: 13\end{array}$ & $\begin{array}{l}\text { Carina: É, só que em vez } \\
\text { deles chegarem ao mesmo } \\
\text { tempo, um deles estava } \\
\text { chegando mais rápido do que } \\
\text { o outro. Então a gente } \\
\text { deixava os dois assim e ... } \\
\text { "tecnicamente” eles batiam } \\
\text { na bancada e voltavam. Aí a } \\
\text { gente media qual é que } \\
\text { voltava mais rápido. }\end{array}$ & $\sqrt{6}$ \\
\hline
\end{tabular}




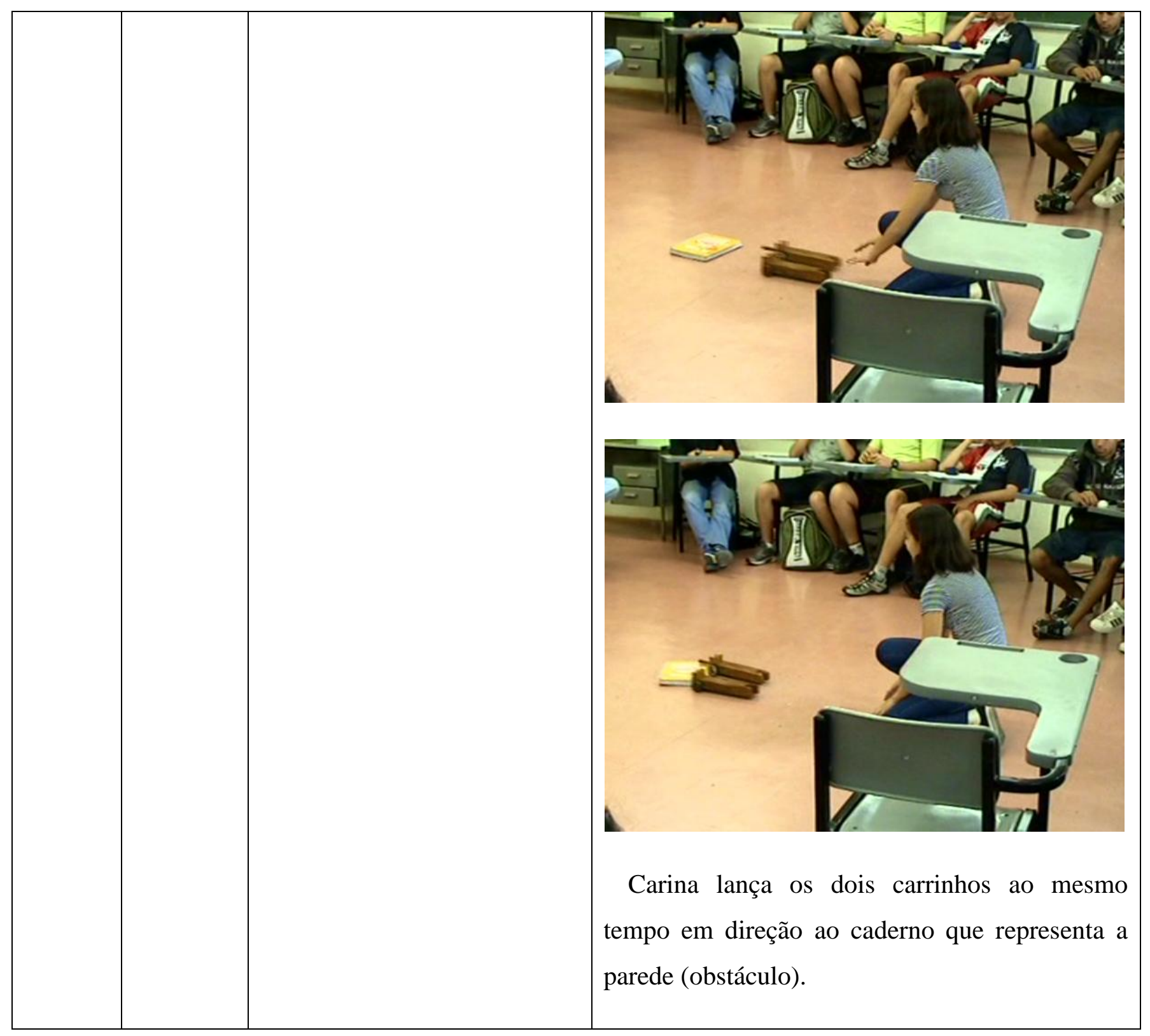

\section{Comentários}

Neste episódio, os alunos procuram demonstrar o que fizeram e o que aconteceu, durante o experimento.

\section{Análise de Dados}

\section{E- A argumentação dos alunos}

Carvalho et al.(1998) dividem a exposição dos alunos em duas fases, a fase do “como" e a fase do "porque". Neste episódio, os alunos estão na fase do "como", pois estão demonstrando como realizaram o experimento. 
Segundo o esquema de Toulmin, (1958), podemos dizer que esta descrição corresponde aos dados que vão suportar uma reivindicação posterior por parte dos alunos.

Parafraseando as falas das alunas Taís e Carina, nos turnos (T.1 a T.11) nós temos a seguinte descrição do experimento:

A gente fez a experiência dos carrinhos batendo na bancada com a mola. A gente lançou os dois carrinhos ao mesmo tempo, <e > eles batiam na bancada <e> voltavam, <mas> em vez deles chegarem ao mesmo tempo, um deles estava chegando mais rápido do que o outro, depois do choque... então a gente deixava os dois assim e eles batiam na bancada e voltavam...<então > a gente media qual é que voltava mais rápido.

F- O entendimento dos conceitos envolvidos

Os alunos, neste episódio, comparam valores de velocidades de dois corpos.

G- As ações do professor

Neste episódio, as ações do professor se concentraram em fazer com que os alunos tomassem consciência da história do experimento (Penick et al, 1996), como se vê nos turnos T.2, T.4, T.7, T.10, pois neste momento, o importante é os alunos descreverem como resolveram o problema proposto (Carvalho et al., 1998).

\subsubsection{Análise do Episódio 14}

Primeira tentativa de descrição do experimento

\begin{tabular}{|c|c|c|c|}
\hline 12 & $\begin{array}{l}26: 14 \\
26: 16\end{array}$ & $\begin{array}{l}\text { Taís: quando batia na } \\
\text { bancada .... quando o } \\
\text { carrinho que tinha a mola } \\
\text { comprimida batia na bancada, } \\
\text { ele voltava mais rápido que o } \\
\text { outro. }\end{array}$ & $\begin{array}{l}\text { Um dos carrinhos que foi lançado contra a } \\
\text { bancada tinha a mola comprimida e o outro tinha } \\
\text { a mola estendida. O que tinha a mola } \\
\text { comprimida batia na bancada (a sua mola } \\
\text { destravava) e voltava mais rápido que o outro. }\end{array}$ \\
\hline
\end{tabular}




\begin{tabular}{|l|l|l|l|}
\hline 13 & $26: 17$ & $\begin{array}{l}\text { Professor: eles percorriam a } \\
\text { mesma distância, é isso? }\end{array}$ & \\
\hline 14 & $26: 18$ & Taís: é. & \\
& $26: 20$ & & \\
\hline
\end{tabular}

\section{Comentários}

Neste episódio, os alunos, depois de terem descrito o que fizeram, relatam o que observaram do experimento (a comparação entre as velocidades dos dois carrinhos, depois do choque deles com a bancada).

\section{Análise de dados}

E- A argumentação dos alunos

A aluna Taís (T.12.) faz uma observação a respeito do experimento (o carrinho que tinha a mola comprimida voltou mais rápido que o que tinha a mola estendida). Esta observação será um dado no esquema de Toulmin (1958) que embasará uma reivindicação dos alunos.

F- O entendimento dos conceitos envolvidos

Os alunos ainda estão trabalhando com o conceito de velocidade, comparando as velocidades dos carrinhos.

G- As ações do professor

O professor continua fazendo com que os alunos tomem consciência da história do experimento (Penick et al., 1996), porém a sua pergunta no turno T.13, além disso, procurou fazer com que os alunos relacionassem as suas observações com o conceito de velocidade média. 


\subsubsection{Análise do Episódio 15}

\section{Descrição da reformulação do plano de trabalho}

\begin{tabular}{|c|c|c|c|}
\hline 15 & $\begin{array}{l}26: 21 \\
26: 24\end{array}$ & $\begin{array}{l}\text { Professor: então, com é que } \\
\text { é, como é que vocês fizeram } \\
\text { para lançar os carrinhos com } \\
\text { a mesma força? }\end{array}$ & \\
\hline 16 & $\begin{array}{l}26: 25 \\
27: 00\end{array}$ & $\begin{array}{l}\text { Taís: não, então, devido a } \\
\text { este grande problema, a gente } \\
\text { começou a lançar um de cada } \\
\text { vez. }\end{array}$ & \\
\hline 17 & $\begin{array}{l}27: 01 \\
27: 05\end{array}$ & $\begin{array}{l}\text { Joana: é, a idéia inicial foi } \\
\text { esta, só que... }\end{array}$ & \\
\hline 18 & $\begin{array}{l}27: 06 \\
27: 15\end{array}$ & $\begin{array}{l}\text { Taís: depois deste big } \\
\text { problema de um ir mais } \\
\text { rápido que o outro...a gente } \\
\text { tentou ao máximo tentar os } \\
\text { dois, mas não dá. A gente não } \\
\text { conseguia medir, então a } \\
\text { gente jogou um de cada vez. } \\
\text { E a gente viu que um voltava } \\
\text { com a mesma velocidade que } \\
\text { foi, mais ou menos no mesmo } \\
\text { tempo, que era o da mola } \\
\text { esticada e o outro, o da mola } \\
\text { comprimida, voltava mais } \\
\text { rápido. Ele ia numa } \\
\text { velocidade e voltava mais } \\
\text { rápido do que foi. } \\
\text { Então, a gente não levou em } \\
\text { consideração, a partir do }\end{array}$ & $\begin{array}{l}\text { Como os alunos não conseguiam lançar os dois } \\
\text { carrinhos com a mesma velocidade, eles } \\
\text { passaram a lançar um de cada vez e comparar } \\
\text { apenas a velocidade de cada carrinho, antes e } \\
\text { depois do choque e não mais comparar as } \\
\text { velocidades dos carrinhos, entre si. Eles } \\
\text { verificaram que, o carrinho em que a mola estava } \\
\text { comprimida voltava mais rápido do que antes do } \\
\text { choque. Verificaram, também, que no outro } \\
\text { carrinho, não havia diferença significativa entre } \\
\text { as velocidades, antes e depois do choque. }\end{array}$ \\
\hline
\end{tabular}




\begin{tabular}{|l|l|}
\hline momento em que a gente \\
jogou um de cada vez, a \\
gente não levou mais em \\
consideração a velocidade \\
dos dois serem a mesma, \\
como eles voltavam.
\end{tabular} \mid

\section{Comentários}

Neste episódio, percebemos que houve uma reformulação do plano de trabalho, o que é um indicador da capacidade do grupo de resolver um problema experimental, bem como um indicador de envolvimento dos alunos com a atividade (Freitas da Silva, 2008). A reformulação do plano de trabalho é possível num problema aberto, em que há a possibilidade de os alunos testarem diferentes formas de experimentação (Guridi e Islãs, 2003).

\section{Análise de dados}

E- A argumentação dos alunos

Neste episódio, os alunos estão descrevendo o que eles fizeram, bem como o que eles observaram. Eles ainda estão na fase do "como". Esta descrição, bem como as observações feitas, são os dados que darão base a uma reivindicação (Toulmin, 1958).

F- O entendimento dos conceitos envolvidos

Eles estão comparando os valores das velocidades, antes e depois do choque.

G- As ações do professor

O professor procura resgatar a história do experimento, fazendo com que os alunos tomem consciência da mesma (Penick et al. 1996). 


\subsubsection{Análise do Episódio 16}

Primeira tentativa de relacionar o experimento com a conservação da quantidade de movimento

\begin{tabular}{|c|c|c|}
\hline 19 & $\begin{array}{l}27: 16 \\
27: 18\end{array}$ & $\begin{array}{l}\text { Professor: como é que vocês } \\
\text { queriam demonstrar se estava } \\
\text { tendo ou não conservação da } \\
\text { quantidade de movimento? }\end{array}$ \\
\hline 20 & $\begin{array}{l}27: 18 \\
27: 21\end{array}$ & $\begin{array}{l}\text { Taís: se tivesse conservação, } \\
\text { ia bater e parar. }\end{array}$ \\
\hline 21 & $\begin{array}{l}27: 21 \\
27: 23\end{array}$ & $\begin{array}{l}\text { Professor: então, se não } \\
\text { houvesse conservação, ia } \\
\text { bater e parar? }\end{array}$ \\
\hline 22 & $\begin{array}{l}27: 24 \\
27: 25\end{array}$ & Taís: é, eu acho que é. \\
\hline 23 & $\begin{array}{l}27: 26 \\
27: 27\end{array}$ & $\begin{array}{l}\text { Professor: se houvesse } \\
\text { conservação, ia bater e voltar, } \\
\text { é isso? }\end{array}$ \\
\hline 24 & $\begin{array}{l}27: 28 \\
27: 29\end{array}$ & Taís: não sei... \\
\hline 25 & $\begin{array}{l}27: 30 \\
27: 33\end{array}$ & $\begin{array}{l}\text { Carina: } \text { se houvesse } \\
\text { conservação, ia continuar na } \\
\text {... Não, vou falar besteira. }\end{array}$ \\
\hline
\end{tabular}

\section{Análise de dados}

E- A argumentação dos alunos

Neste episódio, os alunos estão procurando relacionar o que fizeram com o seu entendimento do princípio da conservação da quantidade de movimento. Eles não estão 
descrevendo o que eles fizeram, nem o que eles observaram, mas buscam uma relação entre suas observações e os conceitos físicos envolvidos. Esta relação, que começa e ser construída neste episódio, é uma justificativa que vai ligar os dados com a reivindicação que será feita pelo grupo (Toulmin, 1958).

F- O entendimento dos conceitos envolvidos

Uma pergunta do professor (T.19) faz os alunos refletirem sobre o conceito da conservação da quantidade de movimento. A resposta da aluna Taís (T.20) mostra que este conceito ainda não está entendido pelos alunos.

\section{G- As ações do professor}

Neste episódio, o professor procura fazer com que os alunos percebam uma relação entre o seu plano de trabalho e suas observações com a proposta inicial que é verificar se, na situação escolhida por eles, há a conservação da quantidade de movimento (T.19, T.23). Agindo assim, o professor está fazendo com que os alunos busquem relações entre a atividade o princípio da conservação da quantidade de movimento. (Penick et al. 1996).

\subsubsection{Análise do Episódio 17}

Relação entre o experimento e a conservação da quantidade de movimento

\begin{tabular}{|c|c|c|}
\hline 26 & $\begin{array}{l}27: 34 \\
27: 44\end{array}$ & $\begin{array}{l}\text { Professor: eu quero saber o } \\
\text { seguinte. Qual foi a idéia, } \\
\text { qual foi a hipótese de vocês } \\
\text { para usar assim. O carrinho, } \\
\text { ele bate... dois carrinhos, } \\
\text { vocês usaram dois carrinhos } \\
\text { com a mesma massa, só que } \\
\text { um estava com a mola } \\
\text { estendida e o outro não, não é } \\
\text { isso? Lançam os dois } \\
\text { carrinhos, teoricamente com } \\
\text { a mesma velocidade até que } \\
\text { eles batem e voltam. Qual é a }\end{array}$ \\
\hline
\end{tabular}




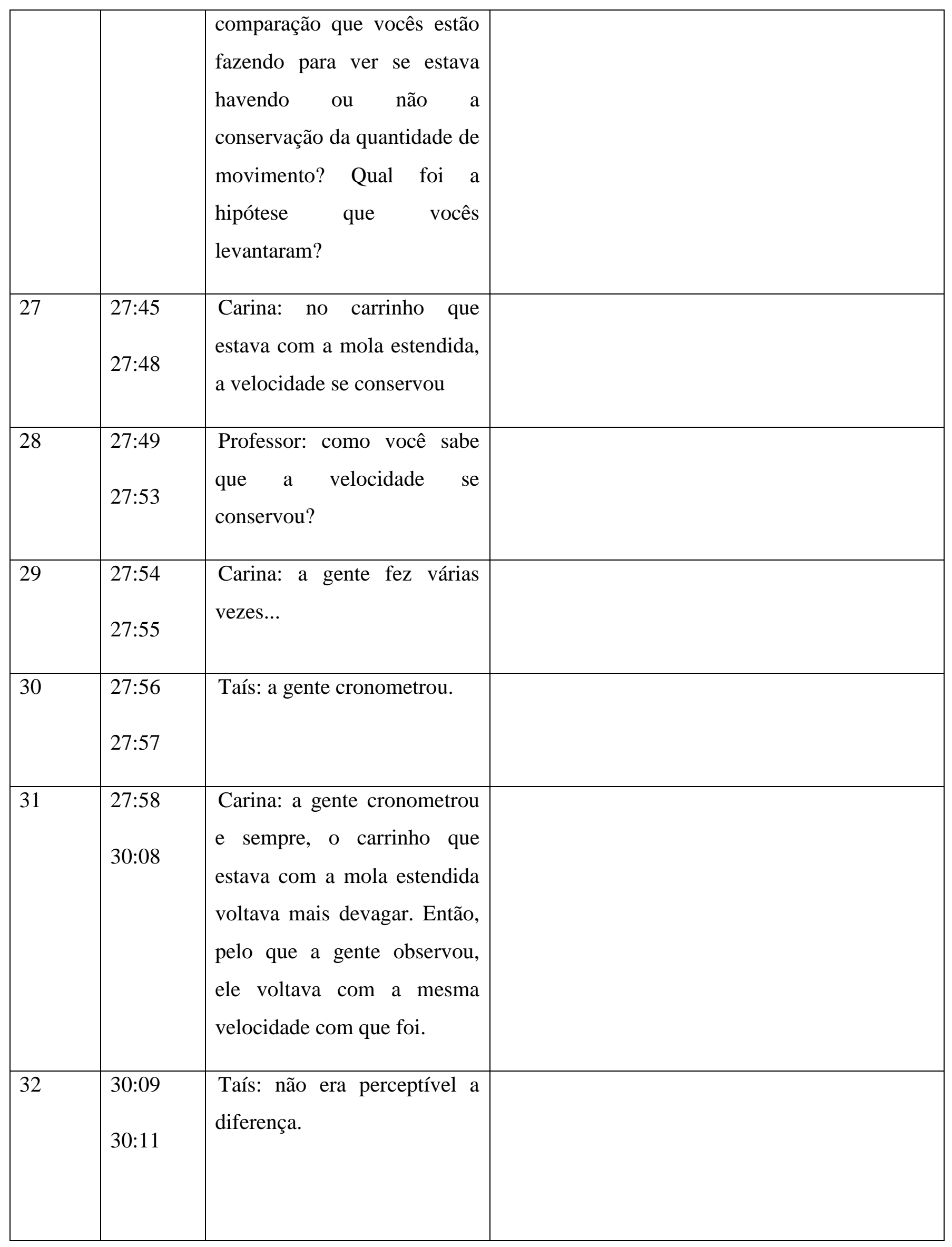




\begin{tabular}{|l|l|l|l|}
\hline 33 & $30: 12$ & $\begin{array}{l}\text { Professor: ele ia e voltava no } \\
\text { mesmo tempo? }\end{array}$ & \\
\hline 34 & $\begin{array}{l}30: 15 \\
30: 18\end{array}$ & Carina: é. & \\
\hline 35 & $30: 19$ & $\begin{array}{l}\text { Taís: e o outro ia no mesmo } \\
\text { tempo e voltava mais rápido. }\end{array}$ & \\
\hline 36 & $30: 22$ & $\begin{array}{l}\text { Professor: qual? } \\
\text { 30:23 }\end{array}$ & $\begin{array}{l}\text { Carina: } \\
\text { comprimida. }\end{array}$ \\
\hline 37 & $30: 25$ & mola & \\
\hline
\end{tabular}

\section{Comentários}

Neste episódio, o professor procura fazer com que os alunos organizem melhor as suas idéias e descrevam com mais detalhes o que eles fizeram, e quais foram as suas observações.

\section{Análise de dados}

E- A argumentação dos alunos

Neste episódio, os alunos descrevem o que eles fizeram (T.29, T.30, T.31), bem como o que eles observaram (T.27, T.31, T.35, T.37), agora com um pouco mais de detalhes. Eles ainda estão na fase do "como" (Carvalho et al., 1998). Esta descrição, bem como as observações feitas, são os dados que darão base a uma reivindicação (Toulmin, 1958).

Parafraseando as suas falas, e buscando nelas a estrutura de pensamento proposta por Lawson (2000), podemos dizer que a descrição do experimento bem como as observações feitas pelo grupo fica da seguinte maneira (o que está entre parêntesis não foi dito pelas alunas, mas subentendido por nós). 
A gente cronometrou (<e> mediu os tempos que cada carrinho levou para ir de um ponto definido até a bancada e o tempo que ele demorou para voltar ao mesmo ponto) $<\mathbf{e}>$, sempre, o carrinho que estava com a mola estendida voltava mais devagar (que o outro que estava com a mola travada e que era solta no choque). <Então>, pelo que a gente observou, ele (o carrinho da mola estendida) voltava com a mesma velocidade com que foi. <Portanto>, no carrinho que estava com a mola estendida, a velocidade se conservou, pois não era perceptível a diferença (da velocidade e da quantidade de movimento do carrinho, antes e depois do choque).

O outro, o de mola comprimida, ia no mesmo tempo (que o da mola estendida) <e> voltava mais rápido (do que foi).

F- O entendimento dos conceitos envolvidos

Neste episódio, as alunas dão uma descrição mais detalhada do experimento e das suas observações e chegam à conclusão que, no carrinho em que a mola estava estendida, o valor da sua velocidade não mudou. Carina falou isto (T.31) em resposta a uma pergunta do professor a respeito da conservação ou não da quantidade de movimento do sistema.

Podemos concluir que para o grupo, no caso do carrinho que estava com a mola estendida, houve conservação da quantidade de movimento, pois o valor da velocidade não mudou com o choque e no caso do carrinho que estava com a mola travada e se destrava com o choque, a quantidade de movimento não se conservou.

Notamos uma enorme evolução conceitual em relação ao episódio anterior, mas os alunos tratam este assunto sem considerar o aspecto vetorial da quantidade de movimento, o que era o esperado, pois o assunto "vetores" ainda não havia sido tratado em sala de aula.

Não se percebe, também, nas falas das alunas, se elas associam a quantidade de movimento com a massa de cada carrinho, apenas o professor (T.26) faz esta associação.

G- As ações do professor

Neste episódio, o professor procura, ao mesmo tempo, ordenar as falas das alunas, para que elas tenham uma consciência mais clara da história do experimento 
(T.26) (Penick et al., 1996 ), além de fazer com que os alunos consigam, efetivamente relacionar o experimento com o princípio da conservação da quantidade de movimento.

Nós notamos, então que o professor concentra as suas ações em dois aspectos da classificação de Penick et al. (1996):

Fazer com que os alunos tomem consciência de:

1) A história do experimento.

2) As relações entre o experimento e os conceitos físicos envolvidos.

Nós notamos, também, que o professor, neste episódio coloca os alunos na fase do "como" (Carvalho et al., 1998), ou seja, na descrição do experimento.

\subsubsection{Análise do Episódio 18}

\section{Conclusões dos alunos}

\begin{tabular}{|l|l|l|l|}
\hline 38 & $30: 40$ & $\begin{array}{l}\text { Taís: por causa da energia } \\
\text { que estava armazenada na } \\
\text { mola que era transferida para } \\
\text { o carrinho ele voltava mais } \\
\text { rápido. }\end{array}$ & \begin{tabular}{l} 
Professor: entendi. \\
\hline 39
\end{tabular} \\
\hline $30: 45$ & $\begin{array}{l}\text { João: o que estava com a } \\
\text { mola esticada amortecia, } \\
\text { agora o da comprimida, ele } \\
\text { funcionava. }\end{array}$ & \\
\hline 40 & $30: 49$ & \begin{tabular}{l} 
Professor: como assim? \\
\hline $30: 57$
\end{tabular} & \\
\hline
\end{tabular}




\begin{tabular}{|c|c|c|}
\hline 42 & $\begin{array}{l}30: 58 \\
30: 06\end{array}$ & $\begin{array}{l}\text { João: o que estava com a } \\
\text { mola esticada ia em direção e } \\
\text { amortecia e o outro não, a } \\
\text { mola impulsionava, era mais } \\
\text { lento. }\end{array}$ \\
\hline
\end{tabular}

E- A argumentação dos alunos

Neste episódio, a aluna Taís (T.38) e o aluno João (T.40) procuram fornecer uma explicação do porque, num carrinho a quantidade de movimento se conserva, segundo a concepção deles de quantidade de movimento. Eles saem da fase do "como" e entram na fase do "porque" (Carvalho et al., 1998).

Segundo o esquema de Toulmin (1958), os alunos realizaram um experimento e fizeram algumas observações. Este experimento e estas observações são os dados que vão embasar uma reivindicação por parte dos alunos. Esta reivindicação está também embasada nos conceitos de velocidade, energia e quantidade de movimento.

Podemos colocar este conjunto da seguinte forma:

\section{1) Dados:}

- Experimento: dois carrinhos são lançados em direção de uma bancada, chocam com ela e voltam.

- Observação 1: um dos carrinhos estava com uma mola estendida. Este carrinho voltou com a velocidade de mesmo valor, aproximadamente, com que foi.

- Observação 2: um dos carrinhos estava com a mola travada. Com o choque, esta mola se destravou e o carrinho voltou com velocidade maior do que antes do choque.

2) Justificativas: (razões propostas que mostram a correlação entre os dados e a conclusão).

Neste experimento, os alunos perceberam que quando a mola destrava, a velocidade do carrinho aumenta, com o choque e quando isto não acontece, não há uma mudança perceptível da sua velocidade. 


\section{3) Apoios}

No esquema de Toulmin, os apoios são suposições básicas que suportam uma justificativa. Neste caso, os apoios são os conceitos abaixo, segundo o entendimento dos alunos e alunas do grupo:

- Velocidade média.

- Quantidade de movimento

- Conservação da quantidade de movimento

- Energia potencial elástica

\section{4) Reivindicação}

O grupo chega à conclusão que a energia armazenada pela mola (no caso do carrinho em que a mola estava travada) impulsionou-o, aumentando sua velocidade.

F- O entendimento conceitual dos alunos

Neste episódio, os estudantes procuram relacionar os conceitos de velocidade e energia, lançando a seguinte hipótese: se a velocidade do carrinho que estava com a mola travada aumentou é porque esta mola destravou e colocou energia no seu movimento (T.38).

Percebe-se nas suas falas (T.38, T.40) que eles conseguem fazer esta relação, entre o aumento do valor da velocidade de um corpo e uma energia introduzida no sistema, no caso, a energia potencial elástica.

G- As ações do professor

Neste episódio, o professor procura ordenar as falas dos alunos no sentido de fazer com que elas tenham maior clareza. Aqui, sua ação não está mais voltada para a história do experimento e sim na relação do experimento com os conceitos físicos envolvidos (Penick et al., 1996 ). Notamos ainda, que não foi necessária nenhuma pergunta específica por parte do professor para que os alunos passassem da fase do "como" para a fase do "porque" (Carvalho et al., 1998). Foi o próprio desenvolvimento das explicações dadas pelos alunos e ordenadas pelo professor que os levou a isto. 


\section{CONCLUSÃO}

Como os alunos resolvem um problema experimental, no qual eles determinam a situação a ser analisada e o procedimento ou o plano de trabalho para resolver o problema? Esta pergunta pode ser transformada em algumas outras mais específicas: que habilidades são trabalhadas pelos alunos, nesta resolução? Que conceitos são mobilizados? Será que esta atividade aproxima os alunos do universo das ciências, ou seja, ajuda no processo de enculturação científica?

E durante a exposição dos alunos para a classe, como isto acontece? Como é a estrutura de pensamento dos alunos? Qual é o entendimento deles em relação aos conceitos envolvidos?

Carvalho et al. (1998) já haviam mostrado que no ensino fundamental, a elaboração de um plano de trabalho para a resolução de um problema experimental passa necessariamente pela manipulação dos materiais por parte dos alunos. Esta fase de manipulação também é observada nesta pesquisa com os alunos do ensino médio.

Podemos concluir que, para a resolução de um problema experimental, esta fase é importante tanto no ensino fundamental, quanto no médio, pois é ela que possibilita que os alunos relacionem os conceitos abstratos da Física com a situação concreta a ser trabalhada. É nesta fase que possibilidades são testadas e surgem as ideias para o plano de trabalho.

Depois da manipulação dos materiais, os alunos partem para a elaboração do plano de trabalho. Nesta fase, o entendimento dos conceitos (velocidade, quantidade de movimento e sua conservação) pelos alunos é mobilizado para a resolução do problema. Esta mobilização de conceitos é um dos objetivos a serem alcançados por uma atividade didática, segundo diversos autores (Lunetta et al., 2007; Guridi e Islãs, 2003). Isto acontece nesta atividade. Percebemos que o entendimento dos alunos a respeito de velocidade, quantidade de movimento e sua conservação é mobilizado na resolução do problema experimental. 
Agora, quando estes conceitos são mobilizados, a atividade exige o desenvolvimento da habilidade de resolução de problemas experimentais, como Lunetta et al. (2007) e Gil e Castro (1996) propõem que deve ser uma atividade experimental. Esta habilidade é exigida quando os alunos resolvem medir a velocidade dos corpos antes e depois do choque entre eles.

Nós percebemos que a aplicação de um conceito simples ganha uma nova dimensão quando ele é transportado para o mundo experimental. $\mathrm{O}$ "como medir estas velocidades" torna-se o foco da atenção dos estudantes durante boa parte da atividade, exigindo diversas repetições do procedimento escolhido e até a reformulação do plano de trabalho, reformulação esta que, como sugerem Gil e Castro (1996), uma atividade didática experimental deve possibilitar aos estudantes.

Os alunos conseguem vencer as dificuldades apresentadas, logo podemos concluir que há o desenvolvimento da habilidade de resolução de um problema experimental por parte dos alunos, nesta atividade.

A comemoração dos estudantes, quanto eles conseguem vencer esta dificuldade, bem como os indicadores de envolvimento com a atividade (Freitas da Silva, 2008) presentes, nos permite concluir que há um envolvimento efetivo dos estudantes com a atividade, ou como dizem Jiménez et al. (2000), os alunos não só "fazem lição". Eles também "fazem ciência". O desenvolvimento da habilidade de resolver um problema experimental coloca os alunos com uma situação típica dos cientistas que é justamente como obter dados confiáveis para testar uma hipótese, ou seja, concluímos que os alunos entram em contato com este universo (Driver et al., 2000) através desta atividade.

Durante a exposição de cada grupo para toda a classe, percebemos nitidamente que na maior parte do tempo, os alunos demonstram o que fizeram e descrevem o que observaram. Em um dos grupos analisados não se percebe em nenhum momento, uma discussão, por parte dos estudantes a respeito do porque a quantidade de movimento do sistema se conserva ou não. Assim, o foco do trabalho fica em como obter os dados necessários para o teste da hipótese levantada, e não no porque hipótese em si (a conservação da quantidade de movimento do sistema) é verdadeira ou falsa. No outro grupo, esta discussão aparece e surgem interessantes relações entre força, energia e 
velocidade nas falas dos alunos. Concluímos daí que, novamente acontece uma interessante similaridade entre as nossas observações e o que foi observado por Carvalho et al. (1998) com alunos do ensino fundamental. Tanto na nossa pesquisa, quanto na pesquisa de Carvalho et al., quando os alunos expõem o seu trabalho, necessariamente passam pela fase de "como", ou seja, da descrição do que aconteceu e alguns conseguem chegar à fase do "porque", ou seja levantam novas hipóteses para explicar o que aconteceu.

Durante a exposição dos trabalhos dos alunos, também percebemos pela nossa análise das falas e ações dos alunos, a estrutura de pensamento de proposta por Lawson e também a formatação lógica de Toulmin, portanto podemos dizer que os alunos, durante a atividade, tiveram a oportunidade de relacionar procedimentos experimentais e dados, ambos obtidos por eles, com conceitos físicos para justificar uma reivindicação.

Quanto ao entendimento conceitual dos estudantes, este é nitidamente percebido através das ações e falas dos estudantes. Podemos dizer, então, que esta atividade é um bom instrumento de avaliação do processo de ensino-aprendizagem. Entretanto, percebemos erros conceituais nas falas e ações dos alunos e estes erros não foram sanados durante a atividade.

Assim com tudo isso, podemos concluir que os grupos analisados se motivaram com o problema proposto, mobilizaram os seus conhecimentos e habilidades na sua resolução e concretizaram o seu entendimento conceitual numa situação palpável. Depois, eles conseguiram estruturar logicamente dados embasados pelo seu entendimento conceitual para justificar uma reivindicação.

Em outras palavras, podemos concluir que com esta atividade, os alunos se aproximaram um pouco mais do universo das ciências, ou seja, ela contribuiu para a enculturação científica dos estudantes. 


\section{REFERÊNCIAS BIBLIOGRÁFICAS}

AMERICANS ASSOCIATION FOR THE ADVANCEMENT OF SCIENCE. (AASP) Project 2061: Science for all americans, 1989.

ARAÚJO, M. S. T. \& ABIB, M. L. Atividades experimentais no ensino de física: diferentes enfoques, diferentes finalidades. Revista Brasileira de Ensino de Física, v. 25, n.2, 2003

BORGES, A. T.; BORGES O.;VAZ, A. Os planos dos estudantes para resolver problemas práticos. Revista Brasileira de Ensino de Física, v.27, n.3, 2005

BRYCE, T. G. K. \& ROBERTSON, I. J. What can they do? A review of practical assessment in science. Studies in Science Education, v.12, p. 1-24, 1985.

CAPECCHI, M. C. V.M \& CARVALHO, A. M. P,. Interações discursivas na construção de explicações para fenômenos físicos em sala de aula. Atas do VII EPEF, Florianópolis SC, 2000.

CARVAlHO A. M. P. et al. A História da Ciência, a Psicogênese e a resolução de problemas na construção do conhecimento em sala de aula. Revista da Faculdade de Educação (USP) v.19, n.2, 1993.

CARVALHO, A. M. P. et al. Ciências no Ensino Fundamental, Escrituras Editora, São Paulo, 1998.

CARVALHO, A. M. P. Uma metodologia para estudar os processos de ensino e aprendizagem em sala de aula. A Pesquisa em Ensino de Ciências no Brasil e suas Metodologias . Editora Unijuí, p. 13 a 48, 2006.

CARVALHO, A. M. P. Enculturação científica, uma meta do ensino de Ciências. XIV ENDIPE, 2007.

CHERNIKOFF et al. Una sencilla experiencia para estudar la Ley de Boyle. Caderno Catarinense de Ensino de Física., v.16 n.2. p. 176-179, 1999.

DRIVER, R.; NEWTON, P.; OSBORNE, J Establishing the norms of scientific argumentation in classrooms. Science \& Education, v. 84, n.3, 2000.

DRIVER, R.; NEWTON, P. Establishing the norms of scientific argumentation in classrooms. Paper prepared for presentation at the ESERA CONFERENCE, Rome, 1997.

DUSCHL, R.A. \& OSBORNE, J. Supporting and promoting argumentation discourse in science education. Studies in Science Education, v.38, p. 39-72, (2002). 
GIL \& CASTRO, La orientación da las prácticas de laboratório como investigación: um ejemplo ilustrativo. Enseñanza de las Ciências, v.14, n.2, 1996.

GIL et al. Tiene sentido seguir distinguindo entre aprendizaje de conceptos, resolución de problemas de lápiz y papel y realizacion de practicas de laboratório? Enseñanza de las Ciências, v.17, n.2, 1999.

GIL et al. Para uma imagem não deformada do trabalho científico. Ciência e Educação, v.7, n.2, 2001.

GREF (http://axpfep1.if.usp.br gref/mecanica.htm) ( mec1 pag13 a 28), 2008

GURIDI, V.M. \& ISLAS, S.M., Guias de laboratorio tradicionales y abiertas em física elemantal. Propuesta para diseñar guias abiertas y estúdio comparativo entre El uso de este tipo de guias y guias tradicionales. Investigações em Ensino de Ciências, 2003.

HOFSTEIN, A. et al. Assessment of the learning environment inquiry-type laboratories in high school chemistry. Learning Environments Research, vol. 4 p.193-207, 2001.

HOFSTEIN, A. \& LUNETTA, V.N. The laboratory in science education: Foundation for the $21^{\text {st }}$ century. Science Education, v.88, p.28-54, 2004.

JIMENEZ, A. et al. "Doing the lesson" or "doing science": Argument in high school genetics. Science Education, v.84, n.6, 2000.

KANNARI, Z. \& MILLAR, R. Reasoning from data: How students collect and interpret data in science investigations. Journal of Research in Science Teaching, v.41, p. 748-769, 2004.

KUHN, D. Science as argument: implications for teaching and learning scientific thinking. Science Education, v.77, n.3, p.319-337, 1993.

LABURU et al. Problemas abertos e seus problemas no laboratório de física: uma alternativa dialética que passa pelo discurso multivocal e univocal Investigações em Ensino de Ciências, v.8, n.3, 2003.

LAND, S. \& ZEMBAL-SAUL, C Scaffolding reflection and articulation of scientific explanations and cognitive learning environment: An investigation of Progress Portfolio. Education Technology Research \& Development, v.51, n.4, p.67-86, 2003.

LAWSON A. E. What does Galileo's Discovery of Jupiter's Moons Tell Us About the Process os Scientific Discovery? Science \& Education, v. 11, 2002.

LAWSON A. E. T. rex, the crater of doom, and the nature of scientific discovery. Science \& Education, v. 13, 2004.

LOCATELLI, R. J. Uma Análise do Raciocínio Utilizado pelos Alunos ao resolverem os Problemas Propostos nas Atividades de Conhecimento Físico Tese de Mestrado (IFUSP), 2006. 
LUNETTA, V.N. ; HOFSTEIN, A; CLOUGH, M.P. Learning and Teaching in the School Science Laboratory: An Analysis of Research, Theory and Practice. Hand Book, 2007.

OLSON, J.K. When hands-on science makes no sense: The role of abstraction and novelty of equipament on learning. Annual Meeting of North Central Association for the Education of Teachers in Science, Dubeque, IA, 2004.

PCN - PARÂMETROS CURRICULARES NACIONAIS - ENSINO MÉDIO. Ministério da Educação - Secretaria de Educação Média e Tecnológica. Brasília 1999.

PCN + ENSINO MÉDIO - Orientações Educacionais Complementares aos Parâmetros Curriculares Nacionais. Linguagens Códigos e suas Tecnologias. - Secretaria de Educação Média e Tecnológica. Brasília: MEC; SEMTEC, 2002.

PENICK, J. E.; CROW, L. W. \& BONNSTETTER, R. J. Questions are the answer. A logical questioning strategy for any topic. The Science Teacher, v. 63, n. 1, p. 27- 29, 1996.

PIZZINI, E.L. ; SHEPARDSON, D.P., ABEL, S.K. A rationale for and development of a problem solving model of instruction in science education. Science Education, v. 73, p. 523-534.

ROTH, W.M.; MCGINN; M.K.; BOWEN, G.M. Interpretations of graphs by university biology students and practicing scientists: Toward a social practice view of scientific representation practices. Journal of Research in Science Teaching, v.36, n.9, 1999.

ROTH, W-M. \& LAWLESS, D. Science, culture and the emergence of language. Science Education, v. 86, n. 3, p. 368-385, 2002.

SANDOVAL, W. A. \& MORRISON, K. High school students ideas about theories and theory change after a biological inquiry unit. Journal of Research in Science Teaching, Vol. 40, pag 369-392, 2003.

SCHWARTZ, R.S. \& LEDERMAN, N.G. "It's the nature of the beast": The influence and knowledge and intentions on learning and teaching the nature of science. Journal of Research in Science Teaching, vol. 39, pag 205-236, 2002.

TOBIN, K.G. Research on science laboratory activities: In pursuit of better questions and answers to improve learning. School Science and Mathematics, vol.90, p.403-418, 1990.

THOMAZ, M. F. A experimentação e a formação de professores: uma reflexão. Caderno Catarinense de. Ensino de. Físicas, V.17 n.3: pag. 360-369, 2000.

TOULMIN S. E. Os Usos do Argumento. São Paulo: Martins Fontes, 1958.

WINDSCHILT, M. Framing constructivism in practice as the negotiation of dilemmas: An analysis of the conceptual, pedagogical, cultural and political challenges facing teachers. Review of Education Research, v. 72, n. 2, p. 131-175, 2002. 


\section{TRANSCRIÇÕES}

\section{Turma 1 Aula 1}

0:00 4:00

Professor: hoje, na terça-feira, nós faremos o seguinte...Normalmente a gente monta um procedimento para que vocês constatem ou investiguem alguma hipótese ou algum conceito. Hoje a gente vai fazer o contrário. O nosso assunto é conservação da quantidade de movimento que a gente já estudou.E para verificar se há ou não conservação da quantidade de movimento, vocês vão se dividir em grupos de no máximo seis pessoas e aí é o seguinte: vocês é quem vão propor o experimento para a gente. A gente trouxe algumas coisas aqui, que podem ou não ser estas, vocês podem pensar em outras coisas...Vocês vão dar uma analisada no material que a gente trouxe e aí, vocês em grupo, vão discutir como é que vocês poderiam montar uma experiência para constatar se há ou não conservação da quantidade de movimento. Para isso, vocês vão ter que discutir no grupo o que é quantidade de movimento, em que situação que ela se conserva, quais são os fatores que vão influenciar no experimento de vocês. Então na aula de hoje, vocês vão observar o que a gente tem e eventualmente, sugerir outras coisas e elaborar um protocolo para constatar ou não a conservação da quantidade de movimento. E aí no final, vocês vão ter que ter um material para me entregar com: qual o procedimento que vocês utilizaram, passo a passo, quais as variáveis que vocês tiveram que controlar. $\mathrm{Na}$ aula que vem a gente vai levar isto para o grupo e aí vocês vão testar estas experiências de vocês e a gente vai discutir o que deu certo, o que não deu certo...Então a partir de agora...só reorganizando os grupos...Vocês podem começar. Há aqui algum material que vocês podem manusear ou se vocês acharem que não precisa, façam a discussão... Tem muita gente aqui. Cinco ou seis pessoas, no máximo. Vamos pessoal! Trabalhar!... vamos, gente! Está tudo paradinho... Aproveitem os materiais, peguem a apostila.

$4: 00 \quad 4: 20$

Carla: e se o outro para trás, com a mesma velocidade, quanto que volta de velocidade?Volta com a mesma medida, né? 
$4: 20 \quad 5: 11$

Patrícia: pega lá a apostila. É este aqui.

5:11 5:17

Carla: tem aí na apostila?

$5: 17 \quad 5: 20$

Daniel: vai. Você soltou

5:20 8:17

Patrícia: Vai

08:17 08:25

Patrícia:...ficou assim, ó.

08:22 08:24

João: o que você fez?

08:26 08:35

Patrícia:a gente pensou em...ver em quantos minutos ele vai chegar...eles vão bater ...e qual ...

08:36 08:37

Carla: a velocidade

08:36 08:39

Patrícia: onde foi que eles bateram

$08: 41 \quad 08: 43$

Carla: ... onde foi os dois?

08:44 08:46

Patrícia:...então alguém tem que marcar. 
08:47 08:52

Carla:...peraí, tem que marcar o tempo.

08:56 08:57

Patrícia: bem aqui..

09:00 09:01

Helena: tem que ser desta risca

09:02 09:03

Carla:dessa aí?

09:03 09:30

Helena: pega uma régua.

09:30 09:31

Patrícia: um, dois, três e já!

09:31 09:32

Aluna 5: parou?!

09:32 09:35

Patrícia: não bateu.

09:35 09:52

Patrícia: um, dois, três e já.

$11: 41 \quad 12: 00$

Marcela: bateram...

12:00 12:03

Patrícia: um, dois, três e já!

12:03 12:10 
Patrícia: faz de novo.

$12: 10 \quad 12: 47$

Daniel: por que não deixa um parado?Por que não deixa um parado?

$12: 47 \quad 12: 49$

Patrícia:está certo.

$12: 49 \quad 12: 52$

Daniel: por que não?

$12: 52 \quad 12: 53$

Daniel: acho...mais fácil.

$12: 53 \quad 12: 54$

Luis: mesma coisa.

$12: 54 \quad 12 ; 56$

Daniel: lógico que não.

$12: 56 \quad 13: 25$

Daniel: deixa um parado! É bem melhor.

$13: 25 \quad 13: 26$

Patrícia: já!

$13: 26 \quad 13: 49$

Marcela: Aqui.

$13: 49 \quad 14: 50$

Carla: um cronometra só aquele. Um cronometra só este.

$14: 50 \quad 14: 55$

Patrícia: como vai medir? 
14:55 15:05

Carla: a hora que ele parar, eu paro

15:05 15:12

Patrícia: a hora que ele bater, você dá uma pausa. Depois, você deixa rodando para ver onde vai parar de vez.

$15: 12 \quad 17: 26$

Carla: você vai anotando as idéias, heim.

17:26 18:06

Patrícia: Oh, Carol, você tira esta régua daqui. Vai Marcos.

18:06 18:14

Daniela: E aí?

$18: 14 \quad 18: 18$

Patrícia: Você marcou os dois tempos?

$18: 18 \quad 18: 20$

Marcela: Não. Na hora que ele bate, tem que parar?

$18: 2018: 28$

Patrícia: Na hora em que ele bate, tem que parar uma vez. Na hora em que ele parar, tem que parar de novo.

18:28 19:10

Carla: vem aqui um pouquinho.

19:10 19:15

Carla: Deu?

$19: 15 \quad 19: 45$ 
Carla: Deu.Deixa eu ver até aonde ele parou. Oh, alguém anota os valores? É isso. Ninguém mexe.

$19: 4519: 57$

Marcela: Quer ajuda aí?

19:57 20:12

Carla: dá um lápis aí. Espera aí.

20:12 20:15

Patrícia: Carol, escreve: carrinho1 e carrinho 2.

$20: 15 \quad 20: 25$

Carla: Dá um lápis aqui, Carol

$20: 25 \quad 20: 39$

Patrícia: agora, vou ditar: põe carrinho 1.

$20: 3920: 55$

Carla: saiu do zero. Escreve, vai escrevendo. Saiu do zero, foi até trinta.

$20: 55 \quad 21: 22$

Patrícia: Marca o setenta e quatro. Não, é a primeira vez. E aí bateu no cinqüenta.

$21: 22 \quad 21: 25$

Helena: Bateu no cinqüenta?

$21: 25 \quad 22: 35$

Patrícia: cinqüenta centímetros. Não mexe não...sete centímetros....zero vírgula seis segundos...e ...continuou indo para frente....depois, andou para frente trinta e quatro centímetros...e até parar....parou em setenta e quatro centímetros....em quanto tempo?

$22: 35 \quad 22: 36$

Marcela: zero vírgula quatro segundos. 
$22: 36 \quad 24: 36$

Patrícia: zero vírgula quatro segundos. ...é zero vírgula quatro só.....Estava parado....a cinquienta centímetros....e depois que bateu....trinta e nove centímetros....Depois que bateu foi até oitenta e nove...em um segundo vírgula noventa e dois....

$24: 36 \quad 25: 07$

Carla: professor, tem uma balança? Leo, tem uma balança? Empresta para nós? Olha aí a balança.

25:07 25:10

Patrícia: eu não sei mexer nesta balança.

$25: 10 \quad 25: 12$

Marcela: Você sabe mexer, Léo?

$25: 12 \quad 25: 13$

Carla :É assim, oh,eu sei.

$25: 1325: 15$

Patrícia: Precisa deste pratinho em cima?

$25: 15 \quad 25: 20$

Marcela: O pratinho é em cima. São três escalas.

$25: 2026: 10$

Patrícia: Põe bem mais para frente....Está certinho... Quinhentos mais trezentos, oitocentos....Carrinho $1,880 \mathrm{~g}$

$26: 1026: 12$

Carla: $180 \mathrm{~g}$ ?

27:12 29:00 
Patrícia: 880 g....Carrinho2...É mais pesado....Tem que mexer no que estava aqui.... Então é novecentos e quarenta gramas...

29:00 29:01

Daniel: Não dá para medir.

29:01 29:20

Carla: Dá sim, a gente acabou de medir...Eu ensino você.

\section{Turma 1 Aula 2}

\section{$1: 38 \quad 2: 20$}

Professor: No comecinho dessa aula, nós pedimos para que vocês pensassem num experimento, desde a elaboração dele, da idéia, tal, que vocês tentassem constatar se havia ou não conservação da quantidade de movimento. Pra isso, vocês devem ter discutido um pouquinho sobre a conservação da quantidade de movimento, e quais as condições que elas se conservam ou não. Certo? E aí, vocês tiveram que bolar o experimento. E a gente vai fazer uma primeira rodada e os grupos vão apresentar para a classe, qual a idéia que vocês tiveram e o que vocês anotaram. Tá? Depois a gente abre para a discussão de cada um deles. Tudo bem? Pode começar Débora.

$2: 20 \quad 2: 26$

Débora: Eu não.

$2: 26 \quad 2: 29$

Professor: Vai vamos lá, quem que é seu grupo Débora? Vamos começar aqui ó!

$2: 29 \quad 2: 31$

Débora: Eu não vou falar.

\section{$2: 31 \quad 2: 32$}

Professor: O Guto fala. 
$2: 32 \quad 2: 33$

Débora: Vai Guto.

$2: 33 \quad 2: 34$

Guto: Porque eu primeiro?

$2: 34 \quad 2: 35$

Professor: Porque nós vamos começar aqui para esquerda.

$2: 36 \quad 2: 37$

Guto: O que a gente fez...

$2: 37 \quad 2: 39$

Professor: Alto, pra todo mundo. Quer demonstrar?

$2: 39 \quad 2: 40$

Guto: Não.

$2: 40 \quad 2: 42$

Professor: Mais a classe precisa ver Guto.

$2: 42 \quad 2: 43$

Débora: Vai Guto.

$2: 43 \quad 2: 44$

Professor: Mostra o que você fez.

$2: 44 \quad 2: 46$

Guto: Faz aí você também!

$2: 46 \quad 2: 47$

Professor: Então vamos. Pega outro carrinho lá.

$2: 47 \quad 2: 48$ 
Douglas: É esse carrinho aqui.

$2: 48 \quad 2: 49$

Professor: Então vai.

2:53 3:02

Douglas: Vai professor, manda outro carrinho aí.

3:02 3:03

Guto: Você vai falando aí!

$3: 03 \quad 3: 18$

Professor: Explica o que vocês fizeram.

$3: 19 \quad 3: 42$

Douglas: Agente colocou o carrinho pra bater na parede e voltar, aí agente cronometrava o tempo antes e depois e via a velocidade que ele ia e a velocidade que ele voltava.

$3: 43 \quad 3: 45$

Professor: O que que vocês fixaram?

$3: 46 \quad 3: 50$

Guto: A distância era sempre a mesma eu queria saber se o tempo de ida e volta era o mesmo.

$3: 51 \quad 4: 00$

Professor: Tá...para aquela distância se o tempo era o mesmo? tá...mostra ai. ....E aí?

$4: 00 \quad 4: 16$

Guto: Sempre que ele ia, ele ia direito e voltava mais rápido. Ele ia com 1 e 42, e voltava com 1 e 40.

$4: 20 \quad 4: 21$ 
Professor: Voltava mais de vagar?

$4: 21 \quad 4: 22$

Guto: Isso!

$4: 22 \quad 4: 23$

Professor: Demorava mais tempo pra ele voltar?

$4: 23 \quad 4: 23$

Guto: Isso.

$4: 23 \quad 4: 25$

Professor: Vocês fizeram várias medidas?

$4: 25 \quad 4: 26$

Guto: Fizemos uma.

$4: 26 \quad 4: 29$

Professor: Tá tudo bem. Entenderam aí classe o que eles fizeram?

$4: 29 \quad 4: 29$

Leandro: Não.

$4: 29 \quad 4: 33$

Professor: Não? Então explica aí Guto!

$4: 33 \quad 4: 43$

Guto: Agente queria saber se o tempo quando saia daqui e batia na parede se era o mesmo entre bater e voltar.

$4: 44 \quad 4: 45$

Professor: O que vocês queriam saber do tempo?

$4: 46 \quad 4: 47$ 
Guto: Pra ver se a quantidade de movimento se conservava.

$4: 48 \quad 4: 50$

Professor: E porque o tempo servia pra mostrar isso?

$4: 51 \quad 4: 58$

Guto: Porque a distância dividida pelo tempo mostra a velocidade e agente queria saber se era igual.

$4: 59 \quad 5: 01$

Professor: Porque a distância era sempre a mesma?

$5: 01 \quad 5: 01$

Guto: Sim.

$5: 02 \quad 5: 06$

Professor: O Debora quer acrescentar mais alguma coisa?

5:06 5:07

Debora: Não.

$5: 07 \quad 6: 10$

Professor: Próximo grupo. Vamos aí! Mostra pra gente o que você tem e o que vocês fizeram.

$6: 12 \quad 6: 45$

Ricardo: A gente ia pegar o carrinho que estava sem peso, ia bater no que tá com peso, que tá com uns 3 quilos e 200gramas e agente ia medir a velocidade que ele bate a gente ia ver a velocidade que o carro que tá parado ia pegar e a velocidade que ele ia voltar.

$6: 46 \quad 6: 48$

Professor: Ai o que vocês mediram?

$6: 49 \quad 7: 07$ 
Ricardo: Ai agente mediu a velocidade primeiro, pegava a régua, media a velocidade, o espaço percorrido por tempo, e aí agente viu que deu mais ou menos, uma das medidas que agente tirou deu $6,72 \mathrm{~cm}$ por segundo.

$7: 07 \quad 7: 10$

Professor: Tá mais a velocidade do carrinho que esta sem os livros é isso?

$7: 10 \quad 7: 11$

Ricardo É.

$7: 11 \quad 7: 12$

Professor: Sempre vocês mediam dele?

$7: 12 \quad 7: 13$

Ricardo: É

$7: 14 \quad 7: 16$

Professor: Tá! Antes de bater?

07:16 $7: 17$

Ricardo: É

$7: 17 \quad 7: 18$

Professor: Depois o que vocês mediam?

$7: 18 \quad 7: 28$

Ricardo: Agente comparava o resultado do carrinho que tava parado na frente do outro e se o carrinho que bateu ele voltou pra esse ponto (inaudível).

$7: 28 \quad 7: 29$

Professor: Não entendi.

$7: 29 \quad 7: 49$ 
Ricardo: Agente via se a velocidade que o carrinho que ele foi bater, se era a mesma, por exemplo, se ele voltava se somasse a velocidade da outra à velocidade que o que tava parado pegou se dá a mesma, pra poder ver depois se a quantidade de movimento tá de volta.

\section{$7: 49 \quad 7: 54$}

Professor: Então se a soma das duas velocidades depois fossem iguais quer dizer aí que a quantidade de movimento conservava?

$7:: 55 \quad 7: 58$

Ricardo: Aí agente ia colocar na fórmula pra ver se tava certo.

$7: 58 \quad 7: 59$

Professor: Que fórmula?

\section{$7: 59 \quad 8: 12$}

Ricardo: É a que quantidade de movimento é igual a massa vezes a direção, e como você falou que anula a massa, a massa é nula os dois carrinhos tem a mesma massa, então agente só médio o peso por ...

\section{$8: 12 \quad 8: 13$}

Professor: Mas eles têm a mesma massa aí?

\section{$8: 13 \quad 8: 13$}

Ricardo: Têm

$8: 13 \quad 8: 14$

Professor: Têm?

$8: 14 \quad 8: 18$

Ricardo: Não! Mas o peso que tá em cima (inaudível).

$8: 18 \quad 8: 19$

Professor: Mas então! Então não é a mesma massa. 
$8: 19 \quad 8: 20$

Ricardo: Então, mas (inaudível).

$8: 20 \quad 8: 27$

Professor: Vocês deixaram um carrinho com a massa dele e o outro carrinho com a massa dele mais os livros?

$8: 27 \quad 8: 28$

Ricardo: É.

$8: 28 \quad 8: 30$

Professor: Aí inicialmente o que estava com os livros ficava parado?

Ricardo: É

$8: 31 \quad 8: 33$

Professor: E aí o outro estava em movimento?

$8: 33 \quad 8: 34$

Ricardo: É

$8: 34 \quad 8: 42$

Professor: Vocês mediam o movimento, a velocidade desse que tava sem peso em cima?

$8: 42 \quad 8: 43$

Ricardo: É.

$8: 43 \quad 8: 46$

Professor: E ai depois vocês mediram a velocidade dos dois carrinhos?

$8: 46 \quad 8: 47$

Ricardo: É.

$8: 47 \quad 8: 49$ 
Professor: Como é que vocês mediam as velocidades dos dois carrinhos?

$8: 49 \quad 9: 17$

Ricardo: Pegou a régua e media o espaço que ele percorria em centímetros e via o quanto tempo ele demorava em determinado espaço.

$9: 18 \quad 9: 26$

Professor: E aí vocês mediam a velocidade dos dois, como vocês acham as massas. E nessa situação tá havendo conservação ou não?

$9: 27 \quad 9: 28$

Ricardo: Tá.

$9: 28 \quad 9: 32$

Professor: Dá os mesmos valores?

$9: 33 \quad 10: 01$

Ricardo: Não mais depois....Bom aí não dava o mesmo, dava é... primeiro dava $8 \mathrm{~cm}$ por segundo e o outro dava $2,5 \mathrm{~cm}$ por segundo, então esses $8 \mathrm{~cm}$ menos esses 2 dava mais ou menos 72 .

10:02 10:03

Professor: De velocidade?

10:04 10:05

Ricardo: É

10:06 10:08

Professor: Mais aí como você constata se conversa ou não o movimento?

10:09 10:10

Ricardo: Porque deu a mesma.

10:11 10:43 
Professor: Tá pensa um pouquinho daqui a pouco agente volta. Quem é o outro grupo ali?

$10: 44 \quad 10: 53$

Carol: Agente pegou uma bolinha e mediu $30 \mathrm{~cm}, 60 \mathrm{~cm}$ e $90 \mathrm{~cm}$.

10:54 10:55

Amanda: Entre a parede.

10:56 10:57

Professor: Tá, a partir da parede vocês fizeram três marcas de distancia, é isso?

$10: 57 \quad 11: 14$

Carol: Aí agente pegou e jogava a bolinha na parede, aí ia ter o tempo né e quando voltava agente fazia o tempo também.

\section{$11: 15 \quad 11: 20$}

Amanda: Agente queria comparar se o mesmo tempo que ia era o mesmo tempo que voltava.

$11: 20 \quad 11: 28$

Professor: Tá, começava a medir o tempo a partir de quando você lançava até bater na parede e via se o tempo para voltar era o mesmo?

$11: 29 \quad 11: 38$

Carol: Na distancia de 30, 60 e 90cm e agente fez várias vezes e não deu.

$11: 39 \quad 11: 43$

Professor: Dava mais ou menos? O tempo para voltar era maior ou era menor? O tempo para voltar era maior?

11:44 11:45

Carol: Era maior. 
11:46 11:53

Amanda: Por causa do impacto, dela com a parede, eu acho!

11:54 11:56

Professor: O que vocês acham?

11:57 12:00

Carla: Por causa do impacto ela volta mais forte.

$12: 00 \quad 12: 01$

Professor: Então ela volta mais rápido?

12:01 12:02

Amanda: Mas ela perde!

12:02 12:03

Carla: Então.

12:04 12:09

Professor: Mais ela falou que era maior o tempo pra voltar! Então ela volta mais devagar. Ela volta mais devagar ou mais depressa?

$12: 09 \quad 12: 18$

Amanda: Mais devagar, porque quanto tem o impacto parece que ela perde a velocidade. No impacto com a parede ela perde.

$12: 19 \quad 12: 21$

Professor: Então ela sempre voltava mais devagar do que ela tinha ido, é isso?

$12: 22 \quad 12: 24$

Carol: Isso. Fala aí as medidas.

$12: 25 \quad 12: 41$ 
Ana: 50 de ida e 62 de volta pra 30cm, 41 de ida e 57 de volta pra $30 \mathrm{~cm}$ também, 32 de ida e 44 de volta pra 60.

$12: 42 \quad 12: 43$

Vitoria: Não é um pouco mais rápido não?

$12: 44 \quad 12: 46$

Professor: Não, esse é o tempo pra voltar. Ela tá falando os tempos. Não é isso?

$12: 46 \quad 12: 47$

Ana: É.

$12: 47 \quad 12: 50$

Professor: Não a velocidade, os tempos que ela demorava para voltar. É isso?

$12: 51 \quad 12: 52$

Ana: É.

12:53 13:07

Professor: Sempre o tempo era maior. E essa diferença era sempre igual? A diferença entre a ida e a volta, marcaram a constante?

13:08 13:09

Carol: Não porque a força não é a mesma.

13:09 13:12

Professor: Quantas vezes vocês mediram?

$13: 13 \quad 13: 28$

Carol: Marcado aí tem duas vezes de cada um, só que agente fez numa outra folha, que agente precisa buscar, que tem mais umas três vezes de cada um, só que também deu diferente, nenhum deu igual.

$13: 29 \quad 13: 30$ 
Professor: Nenhuma situação deu igual?

$13: 30 \quad 13: 32$

Carol: Não, a mais próxima tá aí ô, tem uma que...a não!

$13: 33 \quad 13: 34$

Professor: A vocês descartaram né? Vocês pegaram as que estavam mais próximas pra marcar?

$13: 34 \quad 13: 35$

Carol: É.

$13: 35 \quad 13: 47$

Amanda: É porque agente queria chegar o mais próximo do resultado.

$13: 47 \quad 13: 52$

Professor: Não tudo bem, só quero saber. Mas porque vocês concluem que o que tava mais próximo é que tá certo?

$13: 52 \quad 13: 53$

Amanda: Porque você falou que....

$13: 53 \quad 14: 22$

Professor: Eu não falei nada, eu to perguntando!

$14: 23 \quad 14: 25$

Carol: Não agente só separou!

$14: 25 \quad 14: 33$

Professor: Tem algo mais que vocês querem contar?

$14: 34 \quad 14: 38$

Carol: Agente tá vendo que a de $90 \mathrm{~cm}$ vai mais rápido e quando bate na parede volta muito mais devagar. 
$14: 39 \quad 12: 42$

Professor: Quanto maior a distancia, maior vai ser a diferença para voltar?

$14: 43 \quad 15: 20$

Carol: Isso. O de 90 cm dói com 0,34 centésimos e voltou com 1,9 centésimos, então foi uma diferença muito maior do que o de 30.

$15: 20 \quad 15: 29$

Amanda: Agente tira 20 milésimos que era o tempo que agente aperta, agente médio até isso ô!

$15: 30 \quad 15: 33$

Professor: Então vocês estavam descontando o tempo que tava demorando para ligar e desligar o cronometro?

$15: 34 \quad 15: 47$

Amanda: É lógico!

$15: 48 \quad 15: 49$

Professor: Que mais?

$15: 49 \quad 15: 50$

Carol: Só.

15:50 16:06

Professor: Então primeira conclusão que vocês tiraram então é que, quanto maior fosse a distancia maior a diferença e vocês concluíram então que a volta tá sendo num tempo maior porque o impacto fazia o que?

16:07 16:08

Carol: Parava um pouco a bolinha.

16:09 16:11 
Amanda: Pegava um pouco de movimento da bolinha.

\section{6:12 16:27}

Professor: Então na hora da colisão um pouco do movimento era perdido por conta da colisão, é isso? É? Pessoal quando bate diminui a velocidade, então na hora que tava batendo, uma parte do movimento se perdia por causa da batida, é isso?

$16: 27 \quad 16: 28$

Amanda: Com o impacto.

$16: 29 \quad 16: 30$

Professor: Com impacto, tá.

$16: 30 \quad 16: 33$

Amanda: Não? Tá errado?

$16: 33 \quad 16: 47$

Professor: Eu não disse nada, to só falando, to repetindo o que vocês tão falando, tá? Tem mais alguma coisa eu o grupo quer colocar? Próximo Grupo.

$16: 48 \quad 19: 00$

Patrícia: Então, a gente deixou um carrinho parado a 50 centímetros do outro.

19:01 19:01

Professor: Psiu.

19:02 19:13

Carla: Tava no zero. Aí a gente deixou, empurrou, aí agente viu a hora que ele bateu e que parou.

19:14 19:55

Patrícia: Então, a gente cronometrou o tempo. Quanto tempo demorava pra esse carrinho chegar até bater e quanto tempo demorou para os dois pararem. Desse parar e esse parar. Então, a gente Cronometrou esses três tempos. E também mediu qual foi a distância que eles que eles se 
deslocaram depois da batida. Aí a gente calculou qual era a velocidade por segundo que cada um estava antes e depois da batida e calculou o peso de cada um, a massa dois carrinhos e vimos a quantidade de movimento dos dois carrinhos, antes e depois da batida.

19:56 20:17

Professor: Você entendeu Marcelo? Explica o que elas fizeram, explica o que elas estavam fazendo mesmo. Você entendeu Laura? Não prestou atenção, né?

20:18 20:19

Patrícia: Quer que explique de novo?

$20: 20 \quad 20: 33$

Professor: Faça o favor. Explica mais uma vez e agora se vocês puderem prestar atenção.

$20: 34 \quad 20: 56$

Patrícia: A gente deixou esse carrinho parado a cinqüenta centímetros um do outro. Aí, a gente fez ele mexer e cronometrou quanto tempo demorou para ele bater, quanto tempo demorou para ele parar e quanto tempo demorou para esse parar e ainda mediu, depois da batida, o quanto que eles se mexeram.

$20: 57 \quad 20: 58$

Carla: A gente mediu a massa dos dois.

$20: 50 \quad 21: 15$

Patrícia: E calculando assim, qual é a quantidade de segundos que eles estavam antes e depois que houve a colisão e a massa dos dois, a quantidade de movimento que eles estavam antes e depois. Foi isso que a gente mediu.

$21: 16 \quad 21: 19$

Professor: Primeiro um estava parado e o outro estava em movimento.

$21: 20 \quad 21: 21$

Carla: É.

$21: 21 \quad 21: 23$

Professor: Tá. Ai, vocês mediram a velocidade do primeiro carrinho. 
$21: 24 \quad 21: 25$

Carla: A gente só mediu de um.

$21: 26 \quad 21: 27$

Professor: Só desse carrinho não é isso?

$21: 27 \quad 21: 28$

Patrícia: O outro estava parado.

$21: 29 \quad 21: 30$

Professor: Depois vocês mediram até os dois pararem?

$21: 31 \quad 21: 32$

Carla: Não, assim...

$21: 32 \quad 21: 41$

Patrícia: Mediu a velocidade que eles estavam, gente cronometrou quanto tempo demorou para eles pararem, para saber, para calcular a velocidade deles.

$21: 42 \quad 21: 45$

Professor: Mas, aí, quando eles pararam a velocidade não era zero?

$21: 46 \quad 21: 56$

Patrícia: Não, sim, mas ai a gente calculou quanto centímetros por segundo eles estavam, entendeu? Para saber qual era a velocidade. Quanto eles se mexeram em tantos segundos.

$21: 57 \quad 22: 05$

Professor: Tá. O que eu não estou entendendo muito bem, na verdade não to querendo falar, mas, porque que vocês mediram até que depois que os dois parassem?

22:06 22:13

Patrícia: Pra ver qual era a distância que eles mexeram. Pra calcular, depois qual era a velocidade que eles estavam depois da batida.

$22: 14 \quad 22: 15$ 
Professor: Não, mas, se eles pararam, a velocidade depois não era zero?

$22: 16 \quad 22: 21$

Patrícia: Sim professor, mas é assim: a gente calculou quanto tempo demorou pra eles percorrerem esse caminho.

$22: 22 \quad 22: 23$

Professor: Calcular a velocidade média.

$22: 24 \quad 22: 25$

Patrícia: É, calculou a velocidade que eles estavam.

$22: 26 \quad 22: 27$

Professor: O tempo que eles demoraram até parar?

$22: 27 \quad 22: 34$

Patrícia: É, demorou zero vírgula qualquer coisa para ele parar. A gente viu o quanto que ele mexeu, então, quantos centímetros num segundo ele andaria.

$22: 35 \quad 22: 36$

Professor: Para os dois carrinhos?

$22: 36 \quad 22: 37$

Patrícia: Nos dois carrinhos.

$22: 38 \quad 22: 39$

Professor: E aí, a que conclusão vocês chegaram?

$22: 40 \quad 22: 51$

Patrícia: Sim. O resultado que a gente fez depois da conservação da quantidade de movimento, antes e depois dos dois carrinhos, a soma dos dois, deu um pouco diferente. Não era exatamente igual.

22:52 23:01

Professor: Qual das duas quantidades de movimento foi maior? Antes ou depois?

23:01 23:03 
Patrícia: A de antes foi maior.

23:04 23:05

Professor: Antes foi maior?

23:05 23:07

Patrícia: É antes foi maior.

23:08 23:09

Daniel: Antes foi maior

23:09 23:10

Professor: Em todas as contas? Quantas medidas vocês fizeram?

$23: 11 \quad 23: 12$

Patrícia: Como é que é?

$23: 13 \quad 23: 14$

Professor: Quantas medidas?

$23: 15 \quad 23: 16$

Patrícia: A gente fez uma medida única, a gente fez uma vez só.

$23: 17 \quad 23: 23$

Professor: Fizeram uma única medida e nessa única medida que vocês fizeram, né, o tempo antes...

$23: 23 \quad 23: 24$

Patrícia: A quantidade de movimento antes era maior.

$23: 25 \quad 23: 37$

Professor: A quantidade de movimento antes era maior do que a quantidade de movimento depois. Quer dizer que o antes foi maior, não é isso? Mais velocidade do que a soma dos dois depois? É isso?

$23: 37 \quad 23: 38$ 
Patrícia: É.

$23: 38 \quad 23: 40$

Professor: E a que conclusão vocês chegaram?

$23: 41 \quad 23: 44$

Carla: A gente não tem conclusão professor!

$23: 45 \quad 23: 50$

Professor: O que vocês acham? Porque vocês acham que aconteceu isso?

$23: 51 \quad 23: 53$

Patrícia: Eu acho que teve meio interferência xxxx.

$23: 54 \quad 23: 55$

Professor: Não sei!

$23: 55 \quad 23: 56$

Patrícia: Eu não sei também!

$23: 56 \quad 24: 12$

Professor: Então vamos pensar enquanto eu passo com os outros grupos.

$24: 13 \quad 24: 14$

Alex: Agente fez, mas agente não sabe se tem alguma coisa a haver.

$24: 15 \quad 24: 16$

Professor: Não, mas agente vai colocar para a classe e a classe vai achar a dúvida.

$24: 17 \quad 24: 20$

Alex: Não, mais vai que tá errado e agente vai pagar mico!

$24: 20 \quad 24: 39$

Professor: Não tem importância, certo ou errado a gente ta aqui para aprender. Explica para a classe. 
$24: 39 \quad 24: 40$

Alex: Tem?

$24: 41 \quad 24: 42$

Professor: O que?

$24: 43 \quad 24: 45$

Alex: Energia cinética e potencial tem alguma coisa haver?

$24: 46 \quad 24: 47$

Professor: Não sei!

$24: 47 \quad 24: 48$

Alex: Ah professor fala aí!

$24: 48 \quad 24: 50$

Professor: Vocês têm que mostrar o que vocês fizeram para agente discutir.

$24: 51 \quad 24: 52$

Alex: Mais vai que não tem nada haver.

$24: 53 \quad 24: 54$

Professor: Qual foi o experimento que vocês começaram a fazer e depois vocês mudaram?

$24: 55 \quad 24: 57$

Beto: Igual o do Andre.

24:57 25:00

Professor: Qual era o experimento do Andre?

25:00 25:06

Beto: Media o tempo que o carrinho demorava pra... 
25:07 25:08

Jean: Batia na parede e depois ele voltava.

$25: 09 \quad 25:: 11$

Professor: Vocês estavam medindo o tempo que demorava para bater na parede e depois voltar?

$25: 12 \quad 25: 14$

Jean: Pra ver se voltava com a mesma velocidade.

$25: 15 \quad 25: 18$

Professor: Vocês marcaram a distancia ou cavaram uma distancia diferente?

$25: 18 \quad 25: 20$

Jean: Não, agente marcou lá com régua um metro.

$25: 21 \quad 25: 24$

Professor: Um metro. E aí vocês desistiram desse experimento por quê?

$25: 25 \quad 25: 27$

Beto: O Alex não quis!

$25: 27 \quad 25: 28$

Alex: O Alex não quis o......

$25: 29 \quad 25: 31$

Professor: Porque vocês mudaram?

$25: 32 \quad 25: 33$

Alex: Porque não ia dar tempo.

$25: 34 \quad 25: 38$

Professor: Qual era a idéia? Porque vocês acharam que esse experimento não estava dando muito certo? 
$25: 39 \quad 25: 42$

Beto: Porque o tempo tava toda hora mudando.

$25: 43 \quad 25: 44$

Professor: Tanto pra ir como pra voltar?

$25: 45 \quad 25: 46$

Beto: É.

$25: 47 \quad 25: 49$

Professor: Vocês nunca conseguiam lançar com a mesma velocidade?

$25: 49 \quad 25: 50$

Beto: É.

$25: 51 \quad 25: 53$

Professor: Aí vocês mudaram para qual experimento?

$25: 54 \quad 25: 55$

Beto: Aí o Alex vai explicar.

$25: 56 \quad 25: 57$

Professor: Fala Alex.

$25: 57 \quad 25: 59$

Alex: Então fala se tem alguma coisa haver.

26:00 26:02

Professor: O que? Eu não sei qual é o experimento! Mostra, fala oque que é!

26:03 26:04

Alex: Aquele ali ô.

26:05 26:06 
Professor: Aquelas três bolinhas ali?

26:06 26:07

Alex: É.

26:07 26:07

Professor: Ham!

26:08 26:11

Alex: .... e energia tem alguma coisa haver?

$26: 12 \quad 26: 20$

Professor: Tem, mais a gente vai discutir só a quantidade de movimento. Também serve para explicar a conservação de energia, mas a gente vai explicar só a conservação de movimento.

$26: 21 \quad 26: 22$

Alex: Viu, não é?

$26: 22 \quad 26: 23$

Beto: Não. Tá certo!

$26: 24 \quad 26: 25$

Alex: Não, não, não ta não!

$26: 25 \quad 26: 26$

Professor: Eu não disse que não serve.

$26: 27 \quad 26: 27$

Beto: Viu!

$26: 28 \quad 26: 31$

Jean: Vai fala agora.

$26: 32 \quad 26: 33$ 
Professor: Vamos!

$26: 33 \quad 26: 37$

Alex: Passa aí. Não, não vou!

$26: 38 \quad 26: 49$

Professor: Mostra aí! O Alex tá pouco tempo de gravação pra gente mostra pra Tati vai!

$26: 50 \quad 26: 52$

Alex: Ah professor!

$26: 52 \quad 27: 21$

Professor: Fala o que você quer fazer vai, o Pedro mostra aqui vai. Fala o que vocês quiserem e eles repetem o que vocês estão pedindo.

$27: 22 \quad 27: 23$

Alex: Ergue uma bolinha.

$27: 24 \quad 27: 26$

Professor: Ergue uma bolinha, vai Fernando.

$27: 27 \quad 27: 30$

Alex: Daí ta zero.

$27: 30 \quad 27: 31$

Professor: Ham!

$27: 32 \quad 27: 35$

Alex: Daí a energia potencial, alterou.

$27: 36 \quad 27: 37$

Professor: Nós estamos pensando em quantidade de movimento.

$27: 38 \quad 27: 44$ 
Alex: Ta. Daí...(inaudível)

$27: 45 \quad 27: 50$

Professor: Aí você solta como ele fez, e você médio o que? Aí você solta a bolinha e mede o que?

$27: 51 \quad 27: 52$

Alex: O movimento se conserva lá ô!

27:52 27:55

Alex: Aí aquela lá que tava ali ô.

$27: 56 \quad 27: 57$

Professor: A da sua esquerda.

27:58 28:01

Alex: É, daí ela vai com a mesma velocidade e da mesma altura.

28:02 28:05

Professor: Como é que você sabe isso? Como é que você mediu isso?

28:06 28:14

Alex: Visão. Não é, porque o ângulo da certo e a gente fez essa angulação.

$28: 15 \quad 28: 29$

Professor: Então vamos lá ô! Ergue a primeira lá. Vocês ergueram isso, não solta vem com a mão, levou até bater, é isso?

$28: 29 \quad 28: 30$

Alex: É

$28: 31 \quad 28: 33$

Professor: Aí vocês mediram que tempo? O tempo que demorou pra bater?

$28: 33 \quad 28: 38$ 
Alex: Não, não medimos nada.

$28: 39 \quad 28: 44$

Professor: Então o que vocês fizeram? O que vocês queriam fazer com isso?

$28: 45 \quad 46$

Alex: A gente queria fazer...

$28: 46 \quad 28: 47$

Professor: Mas o que vocês queriam fazer?

$28: 47 \quad 28: 53$

Alex: Queria mostrar que a outra lá tinha a mesma velocidade e altura.

$28: 54 \quad 28: 55$

Professor: E como é que vocês fariam isso?

$28: 55 \quad 28: 56$

Alex: Medindo.

$28: 56 \quad 28: 57$

Professor: Medindo o que?

$28: 57 \quad 28: 58$

Alex: O tempo.

28:59 29:00

Professor: O tempo pra que?

29:00 29:04

Alex: Pra aquela ali bater na bolinha do meio, e o tempo daquela dali subir até a altura que soltamos a outra.

29:05 29:10 
Professor: Então a hipótese de vocês era essa? Vai lá Flavio. Vocês iam fixar uma altura?

29:10 29:11

Alex: É

29:11 29:15

Professor: Solta. Não solta não, desce. Isso! Aí media esse tempo, é isso?

$29: 16 \quad 29: 17$

Alex: É. Até bater na bolinha.

$29: 18 \quad 29: 23$

Professor: Ta, aí vocês iam medir depois o tempo que outra bolinha, que o Guto ta mexendo agora, pra chegar na altura que largava a outra?

$29: 23 \quad 29: 24$

Alex: É.

$29: 24 \quad 29: 26$

Professor: E como é que vocês provariam que estava conservando?

$29: 26 \quad 29: 27$

Alex: Ham?

$29: 27 \quad 29: 28$

Professor: Como é que vocês provariam que estava conservando?

$29: 28 \quad 29: 29$

Beto: Se fosse a mesma.

$29: 29 \quad 29: 34$

Professor: Se fosse o mesmo tempo que ela ia demorar pra atingir a mesma altura? É isso? 
$29: 34 \quad 29: 35$

Beto: É.

$29: 35 \quad 29: 36$

Professor: Sempre ia ser assim?

$29: 37 \quad 29: 38$

Beto: Não a condição...

$29: 39 \quad 29: 50$

Professor: Que condição tinha que tá acontecendo para isso ser verdade? OQue que tinha que acontecer com a primeira bolinha? A que vocês soltaram. Oque que tinha que acontecer?

29:51 29:52

Beto: Ela tinha que ficar parada.

29:53 29:55

Professor: Ela tinha que ficar parada. E se ela não ficasse parada?

29:56 29:57

Beto: Aí ia mudar tudo.

$29: 58 \quad 30: 01$

Professor: E o que, que ia acontecer com a terceira bolinha aqui?

30:02 30:03

Beto: Ia mudar a velocidade.

30:03 30:04

Professor: Mais ou menos?

30:04 30:08

Jean: Depende. 
30:08 30:09

Professor: Depende do que?

30:09 30:12

Jean: Como vai saber?

$30: 13 \quad 30: 14$

Professor: Ué mais vocês não estão medindo?

$30: 14 \quad 30: 15$

Alex: Mais ela fica parada professor.

$30: 16 \quad 30: 17$

Professor: E se não ficar?

$30: 18 \quad 30: 19$

Alex: Não mais ela fica!

$30: 20 \quad 30: 28$

Professor: Solta uma vez pra ver se ela para. Ela fica parada?

$30: 29 \quad 30: 32$

Alex: Não pode levantar tanto.

$30: 33 \quad 30: 35$

Professor: A não pode levantar tanto? Quer dizer que a altura interfere então?

$30: 35 \quad 30: 37$

Alex: Não, mas também porque tá tudo torto aí!

$30: 38 \quad 30: 40$

Jean: Esses fiozinhos aí também não ajudam!

$30: 40 \quad 30: 41$ 
Professor: A então o fato de estar torto também interfere?

$30: 41 \quad 30: 42$

Alex: A distancia também.

$30: 42 \quad 30: 43$

Beto: As bolinhas estão ovais.

$30: 44 \quad 30: 47$

Jean: A nossa hipótese estava querente!

$30: 48 \quad 31: 16$

Professor: Não, não sei! Eu estou pergunto só para a classe. Tem mais algum grupo? Esse aqui já mostrou né? Bom gente, agora vamos discutir os trabalhos de vocês. Vocês acham que todas as propostas de vocês, atenderam as nossas hipóteses? Qualquer experimento dava para demonstrar? Porque ninguém conseguiu medir então o mesmo valor?

$31: 17 \quad 31: 23$

Patrícia: Eu acho que tem alguma coisa que interfere, por exemplo, no chão, eu ser que tenha o atrito que interfira na velocidade.

$31: 24 \quad 31: 28$

Jorge: O chão pode ter uma inclinação também, o atrito do carrinho, da bolinha também....

$31: 29 \quad 31: 31$

Patrícia: O carrinho quando passa vai diminuindo a velocidade.

$31: 32 \quad 3: 34$

Professor: Aí acontece o que depois, aumenta ou diminui?

$31: 35 \quad 31: 36$

Patrícia: Diminui. 
$31: 37 \quad 31: 45$

Professor: Então sempre depois menos. Tem alguém que a resposta depois deu maior que a anterior? $\mathrm{O}$ antes?

$31: 46 \quad 31: 46$

Jorge: Não!

$31: 47 \quad 31: 48$

Professor: Que mais interfere?

$31: 49 \quad 31: 53$

Beto: $\mathrm{O}$ vento.

$31: 54 \quad 31: 55$

Professor: Tá ventando aqui na sala?

$31: 56 \quad 31: 56$

Beto: Ta!

$31: 56 \quad 31: 57$

Professor: Tá né?

$31: 58 \quad 32: 01$

Beto: A janela tava aberta ali!

32:01 32:09

Professor: Sei! Aquele experimento que os meninos fizeram dos dois carrinhos de massas diferentes?

$32: 10 \quad 32: 11$

Jorge: O chão! O atrito!

$32: 12 \quad 32: 16$

Professor: Como é que eles poderiam xxxx? 
$32: 17 \quad 32: 18$

Jorge: Tira o asfalto.

$32: 18 \quad 32: 19$

Professor: Ham?

$32: 20 \quad 32: 21$

Jorge: A parede ta áspera.

$32: 22 \quad 32: 35$

Professor: Não, nós estamos baseando dois carrinhos com massa diferente. Um estava com livro e o outro não. Como é que dava para saber se estava conservando ou não?

$32: 36 \quad 32: 37$

Beto: Medindo.

$32: 37 \quad 32: 40$

Professor: Medindo o que?

$32: 40 \quad 32: 41$

Beto: A conservação.

$32: 41 \quad 32: 42$

Professor: Você mede a conservação?

$32: 42 \quad 32: 46$

Beto: Dependo do ponto de vista!

$32: 46 \quad 32: 50$

Alex: Velocidade e a massa.

$32: 50 \quad 33: 02$ 
Professor: Escreve aí que estava com dois carrinhos diferentes, um com os livros e o outro sem, como é que dava para observar se estava tendo conservação ou não? Bastava medir só as velocidades?

33:03 33:04

Alex: As massas.

33:04 33:29

Professor: A massa você já não tinha fixado. Então, a gente já tinha fixado as massas, um tinha massa maior que o outro, como é que dava pra eu saber se estava conservando ou não classe?

$33: 30 \quad 33: 43$

Priscila: Massa vezes velocidade.

$33: 44 \quad 33: 55$

Professor: Isso tinha que calcular a quantidade de movimento total, não é isso? E aí verificar se dava o mesmo valor, xxxxx. Fazia diferença se o carrinho parava ou não?

$33: 55 \quad 33: 56$

Dulce: Sim!

$33: 56 \quad 33: 57$

Dulce: Lógico!

$33: 58 \quad 34: 00$

Professor: Se ele parasse o que acontecia?

34:01 34:02

Rita: A velocidade ia à zero.

34:03 34:08

Professor: Desse carrinho? E aí o que acontecia com o movimento do que estava com o livro? 
34:09 $34: 10$

Patricia: Tinha que aumentar.

\section{$34: 11 \quad 34: 18$}

Professor: Ia ser maior né? Ta! Porque aí ia receber todo o movimento do outro, não é isso? Mais e essa $\mathrm{xxxxx}$ de velocidade $\mathrm{xxxxx}$ ?

$34: 18 \quad 34: 19$

Patricia: Não.

$34: 19 \quad 34: 20$

Professor: Por quê?

$34: 21 \quad 34: 23$

Patricia: Porque a massa dele é maior.

$34: 24 \quad 34: 58$

Professor: No caso do experimento de vocês, medir até o ponto que para, ou fixar uma distancia mediana, faria diferença? Vocês fizeram assim, um carrinho parado, um carrinho em movimento, bateu, aí vocês mediram até que os dois parassem, certo? Se, ao invés de medir, até que os dois parassem vocês fixassem uma distancia, por exemplo assim, quanto tempo vai demorar para andar, sei lá, $30 \mathrm{~cm}, 40 \mathrm{~cm}$, ia dar diferença no resultado de vocês?

34:59 35:03

Patrícia: A se a gente solvesse a velocidade...

35:04 35:07

Professor: Não vocês iam calcular a velocidade, vocês não mediram o tempo?

$35: 07 \quad 35: 08$

Patrícia: Sim.

$35: 09 \quad 35: 10$ 
Professor: Daria diferença?

$35: 11 \quad 35: 16$

Patrícia: Não, se a gente soubesse qual seria a velocidade dele até chegar nessa distancia...

$35: 17 \quad 35: 19$

Professor: Mais com é que você saberia a velocidade dele até chegar nessa distancia?

$35: 20 \quad 35: 22$

Patrícia: Então a gente...

$35: 23 \quad 35: 25$

Professor: Não dá para por a expressão no quadro?

$35: 26 \quad 35: 27$

Patrícia: A gente cronometrou.

$35: 28 \quad 35: 36$

Professor: Põe lá Flavio, faz favor.

$35: 37 \quad 35: 41$

Patrícia: Mais é que assim, eu acho que teria que saber já qual seria a velocidade dele.

$35: 42 \quad 35: 44$

Professor: E como é que você saberia a velocidade? Em algum momento você sabe a velocidade?

$35: 45 \quad 35: 46$

Patrícia: Não, só depois.

$35: 47 \quad 35: 50$

Professor: Mais aí vocês mediram o que para saber a velocidade?

$35: 51 \quad 35: 56$ 
Patrícia: A gente mediu quanto tempo, tempo em relação a distancia.

35:56 36:09

Professor: Então que você acha, se fixasse a distancia depois de ter medir também o tempo? Se ao invés de vocês medirem até o impacto, que foi o que vocês fizeram, vocês tivessem falado assim ô, vamos ver quanto tempo ele demora para andar $30 \mathrm{~cm}$, não dava pra saber a velocidade?

$36: 10 \quad 36: 11$

Patrícia: Se ele chegasse a $30 \mathrm{~cm}$.

$36: 12 \quad 36: 19$

Professor: Ou 20 ou 10, to dizendo assim, fixar um valor de uma distancia, ia fazer diferença na media de vocês?

$36: 20 \quad 36: 21$

Patrícia: Acho que não.

$36: 21 \quad 36: 26$

Professor: Não? O que vocês acham classe?

$36: 2 \quad 36: 28$

Patrícia: A professor, talvez sim.

$36: 29 \quad 36: 1030$

Professor: Por quê?

$36: 31 \quad 36: 34$

Patrícia: Porque ele ia diminuindo a velocidade dele.

$36: 35 \quad 36: 45$

Professor: Se vocês esperassem até ele parar, não é, cada hora a velocidade estaria menor até chegar a zero, não é isso? A perda não seria maior, do que vocês olharem um pedaço mais curto? 
Patrícia: É.

$36: 46 \quad 38: 22$

Professor: Gente na verdade eu to chamando atenção para isso, porque quando a gente mede a quantidade de movimento, agente mede assim, no instante que ta colidindo e exatamente depois, quanto mais tempo a gente demorar, maior vai ser a interferência que tem, não é? Eles esperaram até o carrinho parar, eu ainda chamei a atenção, mais aí não chegou na velocidade zero? É outra situação, então de repente a gente medir enquanto a velocidade ainda esta mais ou menos constante, antes dele começar a perder velocidade, ta? Talvez facilitasse mais, tem algum comentário que vocês queiram fazer? Professor: O que que vocês acham? Bom, eu vou pedir para vocês então, tentarem concluir, a partir da discussão do grupo tá, quais fatores que influenciam na conservação na quantidade de movimento, como é que vocês poderiam fazer para aprimorar cada um dos experimentos que vocês fizeram, na sexta-feira que vem que é nossa próxima aula, cada grupo vai me trazer tá, pra gente fazer a avaliação do que propôs o experimento e a partir disse o que que precisa alterar.

\section{Turma 2 Aula 1}

0:00 1:08

Professor: ... no final da aula, vocês vão me entregar um papel, dizendo qual foi o caminho que vocês fizeram. Na próxima aula, vocês vão testar os experimentos e aí a gente vai discutir se deu certo, se não deu certo, porque, etc. Tudo bem? Então, mãos à obra. O material que a gente está trazendo é este aqui. Se vocês tiverem outros que vocês imaginarem, vocês podem utilizar. Entenderam? Tem alguns materiais aqui e eventualmente, vocês podem ter outros. Qual é a idéia? Vocês, em grupo, vão elaborar um protocolo para uma experiência para provar ou não se existe a conservação da quantidade de movimento. Vocês vão elaborar um experimento para que vocês testem a hipótese da conservação da quantidade de movimento. Num primeiro momento, vocês olharam e agora vocês vão discutir o que vocês querem fazer.

$1: 09 \quad 1: 36$

Débora: professor!

$1: 37 \quad 2: 22$

Professor: calma, calma. 
$2: 23 \quad 2: 24$

Carlos: e se a mola travar?

$2: 25 \quad 2: 27$

Carina: o professor falou para a gente travar.

$2: 28 \quad 2: 33$

Carlos: então aperta aí.

$2: 34 \quad 2: 49$

Janice: neste caso, a mola da frente é comprimida

$2: 50 \quad 2: 52$

Artur: pega a apostila.

$2: 52 \quad 2: 57$

Cláudia: esta aí eu lembro.

$2: 57 \quad 3: 01$

Artur: pega lá a apostila. Lá tem.

3:02 5:59

Pedro: Léo, pega o outro aí. Manda aí.

$6: 00 \quad 6: 10$

Professor: como hipótese, pode constar aí. Como você prova uma hipótese condicional? Como você vai saber se é mais rápido?

$6: 11 \quad 6: 15$

Carina: porque chegou mais rápido ali.

$6: 16 \quad 6: 25$

Professor: não. Você tem que pegar o cronômetro, para anotar o tempo, aí você calcula a velocidade.

$6: 26 \quad 6: 30$

Carina: a gente pode usar este tempo?

$6: 31 \quad 6: 36$

Professor: pode. Vocês podem usar a técnica que vocês quiserem.

$6: 37 \quad 6: 39$

Cláudia: pode escrever. 
$6: 40 \quad 6: 43$

Cláudia: Guilherme, é assim que escreve.

$6: 44 \quad 7: 05$

Cláudia: professor, tem uma fita crepe?

$7: 06 \quad 7: 10$

Jéferson: vai rápido e vai lento.

$7: 12 \quad 7: 15$

Cláudia: ei, professor? O professor foi pegar a fita?

$7: 17 \quad 7: 35$

Júlio: quem atravessa?

$7: 36 \quad 7: 40$

Cristina: acho que você fez certo.

$7: 41 \quad 8: 05$

Lauro: professor!

8:06 $\quad 8: 15$

Pedro: aqui, aqui.

$8: 16 \quad 8: 20$

Pedro: é só travar. Trava aqui.

$8: 21 \quad 8: 25$

Carina: a gente pode fazer este também?

$8: 26 \quad 8: 29$

Cláudia: o professor já sabe.

$8: 30 \quad 8: 41$

Pedro: tem que completar.

$8: 42 \quad 9: 38$

Carina: deu um minuto.

$9: 39 \quad 9: 41$

Pedro: um minuto?

$9: 42 \quad 10: 17$ 
Professor: como é que você prova isso? Você tem que medir a massa de cada vez e a velocidade de caca vez. Podem testar. Aí vocês usam o cronômetro. Meçam para ver qual é a velocidade, para ver se está certo ou não.

$10: 18 \quad 10: 20$

Carina: professor, a gente estava certo!

$10: 21 \quad 10: 25$

Júlio: vamos usar as bolinhas.

$10: 26 \quad 10: 32$

Carina: vai de novo, vai de novo.

$10: 33 \quad 10: 44$

Cristina: da madeira, a primeira bolinha vai...quando você faz assim na bolinha. Vai parar na outra. Ficou parada.

$10: 45 \quad 11: 15$

Carina: outra vez. Um, dois, três e vai! Não deu esse aqui. Deixa primeiro aquele que a gente acertou, que era esse aqui.

\section{$11: 16 \quad 11: 17$}

Cláudia: Mas a velocidade deve ser esta aqui.

$11: 18 \quad 11: 26$

Carina: e este aqui agora é que passa. Deixa eu ver este aqui.

$11: 27 \quad 11: 29$

Cláudia: faz de novo, espera.

11: $30 \quad 11: 32$

Carina: tem que ser com a mesma força.

$11: 33 \quad 11: 34$

Cláudia: espera.

$11: 35 \quad 11: 38$

Carina: se não o que vale é o primeiro que fez.

$11: 39 \quad 11: 45$

Cláudia: espera aí. Deixa eu cronometrar. Um, dois, três e vai.

$11: 46 \quad 11: 47$

Carina: boa. 
$11: 48 \quad 11: 51$

Cláudia: vai, vai.

$11: 52 \quad 12: 18$

Carina: vai devagar. Um, dois, três e vai.

$12: 19 \quad 12: 20$

Cláudia: dois segundos.

$12: 21 \quad 12: 30$

Cláudia: professor, não destrava.

$12: 31 \quad 12: 37$

Cristina: quebrou. Agora vai ter uma posição.

$12: 38 \quad 12: 56$

Carina: vamos ver o que acontece.

$12: 57 \quad 12: 59$

Pedro: vamos com esse.

13:00 13:05

Cristina: muda a primeira coisa que a gente fez.

$13: 06 \quad 13: 26$

Carina: um, dois, três e ...

$13: 27 \quad 13: 29$

Cláudia: trava.

$13: 30 \quad 13: 37$

Cláudia: a gente tem que ser agitada.

$13: 38 \quad 13: 55$

Carina: um, dois, três e...

$13: 56 \quad 14: 07$

Carina: um, dois, três e vai!

$14: 08 \quad 14: 10$

Carina: um e três.

$14: 11 \quad 14: 40$ 
Cláudia: qual que é a fórmula?

$14: 41 \quad 14: 45$

Carina: está certo, tem menos força.

$14: 46 \quad 15: 14$

Cláudia: o que você escreveu?

$15: 15 \quad 16: 35$

Pedro: solta a bolinha.

$16: 36 \quad 16: 37$

Lauro: deixa ele aqui.

$16: 38 \quad 17: 25$

Carina: está em contato.

$17: 26 \quad 17: 43$

Pedro: falei que era um metro e meio!

17:44 19:03

Carina: tenta de novo.

19:04 19:28

Pedro: joga aí.

$19: 29 \quad 19: 59$

Professor: como você vai medir? Aí você vai medir, como vai sair do zero. De repente, vocês vão medir .

$20: 00 \quad 20: 33$

Cláudia: é, vai.consegue chegar lá.

$20: 34 \quad 20: 46$

Carina: faz aqui.

$20: 47 \quad 21: 15$

Cláudia: este volta mais rápido.

$21: 16 \quad 21: 40$

Carina: presta atenção, presta atenção. Este vai mais devagar ou não?

$21: 41 \quad 21: 51$

Cláudia: a força. 
$21: 52 \quad 21: 55$

Carina: não estou falando da força. Ele vinha mais rápido que este.

$21: 56 \quad 22: 04$

Cláudia: está vendo?

22:05 22:08

Carina: este aqui perde a força. Este aqui ganha a força.

22:09 22:10

Cláudia: como?

$22: 11 \quad 22: 13$

Carina: eu joguei ali.

$22: 14 \quad 22: 42$

Carina: presta atenção. Ele volta mais rápido. Olha.

$22: 43 \quad 22: 45$

Lauro: parece.

$22: 46 \quad 23: 10$

Carina: é um ou outro.

$23: 11 \quad 23: 14$

Cláudia: é, acho que tem que jogar os dois.

$23: 15 \quad 23: 16$

Carina: qual dos dois, mais.

$23: 17 \quad 23: 35$

Cláudia: pega você.

$23: 36 \quad 23: 49$

Carina: este volta.

$23: 50 \quad 23: 51$

Cláudia: eu acho.

$23: 52 \quad 24: 07$

Carina: um, dois, três.

$24: 08 \quad 24: 13$ 
Cláudia: vai, joga você os dois.

$24: 14 \quad 24: 29$

Cristina: primeiro, segundo.

$24: 30 \quad 24: 45$

Carina: devagar, Cristina.

$24: 46 \quad 24: 57$

Cláudia: este aqui trava.

$24: 58 \quad 25: 24$

Cristina: amortece.

$25: 25 \quad 25: 29$

Carina: então na hora, ele deveria voltar mais lento para trás.

$25: 30 \quad 25: 34$

Cláudia: é porque ele é mais pesado.

$25: 35 \quad 25: 36$

Professor: por que ele está voltando mais rápido?

$25: 37 \quad 25: 38$

Cláudia: a gente só viu que ele está chegando mais rápido.

$25: 39 \quad 25: 48$

Carina: tem que ver só o que trava. Ele volta com uma velocidade maior que ele próprio estava.

$25: 49 \quad 25: 50$

Cláudia: mas

$25: 51 \quad 25: 52$

Carina: mas a gente não está conseguindo mandar os dois com a mesma velocidade. A velocidade não é igual.

$25: 53 \quad 25: 54$

Professor: como é que vocês sabem?

$25: 55 \quad 26: 00$

Carina: a velocidade é a distância pelo tempo. 


\section{Turma 2 aula 2}

$0: 05 \quad 0: 24$

Professor: A atividade proposta para a terça passada era montar um protocolo para verificar a conservação da quantidade de movimento. Ninguém terminou?

$0: 25 \quad 0: 26$

Carina: você falou que podia terminar hoje.

$0: 27 \quad 1: 00$

Professor: eu disse a vocês o seguinte: vocês iriam começar a montar na aula passada e a gente iria verificar a possibilidade de vocês terminarem naquela aula e trazerem o relatório pronto para a gente discutir agora. Gostaria de saber quem conseguiu terminar, para a gente entrar na discussão. Caso não seja possível, eu vou dar mais quinze minutos para vocês terminarem. Alguém terminou?Não? Oh, oito e meia e vocês têm quinze minutos exatos para terminar.

$1: 01 \quad 1: 02$

Lauro: professor, cadê o pêndulo?

$1: 03 \quad 1: 04$

Cristina: para que você fez isso?

$1: 05 \quad 1: 06$

Lauro: cadê a velocidade?

$1: 07 \quad 1: 48$

Lauro: que medida?

$1: 49 \quad 1: 527$

Professor: como você faz para medir? O que você deve medir e como você faz para medir.

$1: 58 \quad 2: 06$

Lauro: a gente mediu a velocidade da bolinha, quando a bolinha parava,.

2:07 $2: 13$

Cristina: quando a bolinha...

$2: 14 \quad 3: 04$ 
Lauro: até a amarela ficar novamente ...

3:05 3:08

Cristina: a bolinha

$3: 09 \quad 3: 11$

Lauro: ...leva para subir e cair novamente com as outras. Tinha um momento em que ela para.

$3: 12 \quad 3: 21$

Cristina: eu já escrevi isso.

$3: 22 \quad 03: 24$

Lauro: cai para a posição final...

$3: 25 \quad 3: 52$

Carla: vem cá, aqui o pesinho bate na bolinha. Isso porque é assim. O pesinho impulsiona a bolinha e aí ela vai na direção onde o pesinho estava com a mesma força.

$3: 53 \quad 4: 05$

Júlia: aí o negócio não vai...a gente coloca o negócio quadrado.

4:06 5:05

Maria: não tem fórmula.

5:06 5:08

Cristina: a gente vai fazer o pesinho? O que vai ter que ser feito?

$5: 09 \quad 5: 10$

Maria: por que?

$5: 10 \quad 5: 32$

Cristina: para bater.

$5: 33 \quad 5: 40$

Márcia: está anotando tudo?

$5: 41 \quad 5: 47$

Carina: este é dois...

$5: 48 \quad 6: 23$ 
Carina: tem que explicar o experimento.

$6: 24 \quad 6: 47$

Taís: o experimento é dois carrinhos, um comprimida outro com a mola estendida.

$6: 48 \quad 7: 01$

Lucas: quase bateram.

7:02 8:02

Lucas: estamos com problemas técnicos, o carrinho não quer destravar. Dois carrinhos, a gente vai lançar um carrinho, ele vai empurrar o outro e vai sair com a mesma velocidade que o outro e o outro vai parar.

$8: 03 \quad 8: 13$

Tiago: ele está com a velocidade assim.

$8: 14 \quad 8: 21$

Pedro: problema é ele estar com a mesma velocidade

$8: 22 \quad 8: 23$

Tiago: dois metros é o corredor?

$8: 24 \quad 8: 25$

Pedro: espaço de tempo.

$8: 26 \quad 8: 39$

Jonas: um deles tem a velocidade e vai manter a velocidade.

Tiago: vai parar.

$8: 40 \quad 8: 53$

Jonas: 1 e cinqüenta.

$8: 54 \quad 9: 45$

Tiago: professor, aqui professor, oh. A gente vai jogar o carrinho assim e quando ele bater, a gente vai medir o quanto que andou.

$9: 46 \quad 9: 50$

Professor: quanto ele andou ou qual a velocidade com que ele saiu? Ela estava parado? $9: 51 \quad 9: 52$ 
Tiago: a velocidade que percorreu um espaço.

$9: 53 \quad 9: 54$

Jonas: então ...

$9: 55 \quad 9: 56$

Tiago: o tempo que ele percorreu um espaço .

$9: 57 \quad 9: 58$

Jonas: velocidade.

$9: 59 \quad 10: 26$

Tiago: joga para cá. Vamos lá.

$10: 27 \quad 10: 35$

Jonas: quanto você acha que tem aqui?

$10: 36 \quad 10: 38$

Tiago: precisa ver quantas vezes é maior.

$10: 39 \quad 10: 49$

Jonas: qual é o tamanho disso aqui?

$10: 50 \quad 10: 57$

Tiago: duzentos e cinqüenta.

$10: 58 \quad 10: 59$

Cristina: não é melhor a gente ver?

11:00 11:02

Lucas: vamos lá, professor?

$11: 03 \quad 11: 45$

Professor: todo mundo vai ter que explicar com mais detalhes.

$11: 46 \quad 13: 26$

Tiago: o nosso está fora. Tem que ir descontando.

$13: 27 \quad 14: 59$

Lucas: para. Vai! 
Professor: a idéia era que vocês conseguissem constatar a conservação da quantidade de movimento e a gente pediu para que vocês pensassem desde a elaboração do roteiro, do procedimento que vocês iam fazer até como vocês iriam obter as medidas e quais as medidas que deveriam ser feitas. Agora agente vai fazer o que? Vocês vão apresentar a idéia para a classe,que vocês tiveram. Então, a gente num primeiro momento vai deixar todo mundo falar, apresentar as idéias, depois a gente vai discutir o que é adequado, o que não é adequado, como é que a gente consegue ou não demonstrar ou não se tem conservação ou não e quais os fatores que vão influenciar. A gente pode começar a minha esquerda. $\mathrm{O}$ primeiro grupo pode falar. Explica para a classe o que vocês fizeram.

\section{$16: 15 \quad 17: 08$}

José: a gente viu que a velocidade tinha se conservado, só a tração das forças a gente chegou....Foi para trás.

\section{$17: 09 \quad 17: 13$}

Professor: vocês pegaram um carrinho e lançaram o carrinho contra a parede e aí vocês mediram o quê?

\section{$17: 14 \quad 17: 24$}

Tiago: eles foram e voltaram.

\section{$17: 24 \quad 17: 30$}

Professor: vocês mediram um ponto lá na parede, mediram a distância até a parede e viram para voltar?

\section{$17: 31 \quad 17: 32$}

Lucas: é.

$17: 32 \quad 17: 34$

Professor: o que vocês perceberam? Os valores eram iguais?

$17: 35 \quad 17: 50$

Lucas: eram diferentes. Foi com 79 metros e ....

$17: 51 \quad 17: 52$

Professor: demora mais tempo para voltar, é isso? 
$17: 53 \quad 17: 54$

Lucas; é.

17:55 18:07

Professor: que mais vocês notaram na experiência? È isso? Próximo.

18:08 18:09

Carina: é para mostrar?

$18: 10 \quad 18: 12$

Professor: se quiser mostrar, é melhor.

$18: 13 \quad 18: 20$

Lauro: a gente usou o pêndulo. Nossa idéia é que ...

$18: 21 \quad 18: 23$

Professor: não tem importância. É só para ter uma idéia.

$18: 24 \quad 18: 36$

Lauro: nossa hipótese é que a bolinha vai ter a mesma velocidade ou força que a última.

$18: 37 \quad 18: 38$

Professor: velocidade ou força?

$18: 39 \quad 18: 41$

Lauro: velocidade.

$18: 42 \quad 18: 48$

Professor: como é que vocês fizeram? Mostrem aí. Vocês lançaram a bolinha....

$18: 49 \quad 18: 50$

Andressa: ela saía, chegava e batia na outra. Ela parava e voltava.

18: $50 \quad 19: 09$

Lauro: e aí quando ela batia de novo, parava no alto.

$19: 10 \quad 19: 27$ 
Professor: então, vocês fixaram um ponto para vocês soltarem, não é isso? Mediram o tempo que demorou deste ponto até bater na bolinha da frente. Depois, no instante em que ela batia na bolinha do meio, e depois vocês mediam o tempo que ela demorava até subir.

$19: 28 \quad 19: 30$

Lauro: até o ponto em que ela parava de subir e começava a voltar.

$19: 31 \quad 19: 37$

Professor: então, vocês mediram da hora que ela saía até subir ou até descer?

$19: 38 \quad 19: 40$

Andressa: demorou o mesmo tempo da primeira.

$19: 41 \quad 19: 42$

Professor: entendi.

$19: 43 \quad 19: 46$

Andressa: quando ela saía...

$19: 47 \quad 19: 52$

Lauro: quando ela começava a voltar, a gente começava a marcar o tempo. Quando ela batia, a gente parava.

!9:53 20:04

Professor: ergue a bolinha, vai com a mão. E aí vocês mediram este tempo em que ele está descendo.

$20: 05 \quad 20: 18$

Andressa: e aí quando ela bateu na bolinha parada, aí esta parava, e esta bolinha saía e parava em cima.

20:19: $20: 20$

Professor: então ela estava voltando.

$20: 20 \quad 20: 25$

Andressa: não. Ela parava aqui.

$20: 26 \quad 20: 39$ 
Professor: parava junto? E quem disse para vocês que a distância que elas tinham percorrido era a mesma? Era na mesma altura que parava? Vocês não mediram isto?

$20: 3920: 40$

Andressa: a gente só mediu o tempo.

$20: 41 \quad 20: 47$

Professor: o tempo que uma demorava para descer e o tempo que a outra demorava para subir.

Andressa: é.

$20: 48 \quad 20: 52$

Professor: e como é que vocês constataram se estava conservando ou não? Qual foi a idéia?

20:53 21:03

Lauro: a gente mediu.

$21: 04 \quad 21: 22$

Professor: a gente volta na discussão daqui a pouco. Vamos ver outro grupo. Quem é o próximo? Seu grupo já foi?

$21: 23 \quad 21: 24$

Vanessa: agora é o grupo da Paula.

\section{$21: 25 \quad 21: 26$}

Professor: agora é o grupo da Paula?

\section{$21: 27 \quad 22: 21$}

Paula: a gente fez uma marca. A gente não fez o experimento. A gente previu o experimento. A gente fez algo como se fosse um teto com uma bolinha. É como se fosse um teto, com a bolinha e a bolinha na frente. A gente disse que se o movimento é do térreo, a velocidade é do térreo vezes a massa dele, vai ser o mesmo da massa da bolinha vezes a velocidade.

$22: 22 \quad 22: 23$

Professor: como vocês mediriam esta velocidade?

$22: 24 \quad 22: 56$ 
Paula: primeiro, a gente vai medir a distância, deve ser a mesma do térreo desta bolinha...movimento....A gente vai medir o tempo.

$22: 57 \quad 23: 29$

Professor: e quais os valores que vocês estão medindo então?

$23: 30 \quad 23: 57$

Paula: massa, distância, tempo, que é a velocidade, que é o tempo e a distância.

$23: 58 \quad 24: 13$

Professor: muito bem. Próximo grupo.

$24: 14 \quad 24: 21$

Carina: A gente fez a experiência dos carrinhos batendo na bancada com a mola.

$24: 2224: 23$

Professor: mostra aqui!

$24: 2424: 25$

Joana: Pode ser um só?

$24: 2624: 27$

Professor: Vocês usaram um só?

$24: 2824: 29$

Joana: Na verdade a gente acabou usando dois.

$24: 3024: 35$

Carina: travou a mola.

$24: 36 \quad 24: 37$

Professor: demonstrem o que vocês fizeram.

$24: 3824: 40$

Pedro: coloque o obstáculo

$24: 4124: 52$

Carina: a gente pôs dois carrinhos ao mesmo tempo. Só que, assim, este aqui tinha mais...é maior.

$24: 5324: 54$ 
Professor: Espera aí. Um estava com a mola comprimida e o outro não. É isso?

$24: 55 \quad 25: 13$

Carina: É, só que em vez deles chegarem ao mesmo tempo, um deles estava chegando mais rápido do que o outro. Então a gente deixava os dois assim e ... "tecnicamente" eles batiam na bancada e voltavam. Aí a gente media qual é que voltava mais rápido.

\section{$25: 1425: 16$}

Taís: quando batia na bancada .... quando o carrinho que tinha a mola comprimida batia na bancada, ele voltava mais rápido que o outro.

$25: 17 \quad 25: 18$

Professor: eles percorriam a mesma distância, é isso?

25:19 25:20

Taís: é.

$25: 21 \quad 25: 24$

Professor: então, com é que é, como é que vocês fizeram para lançar os carrinhos com a mesma força?

25:25 26:00

Taís: não, então, devido a este grande problema, a gente começou a lançar um de cada vez.

26:01 26:05

Joana: é, a idéia inicial foi esta, só que...

26:06 26:15

Taís: depois deste big problema de um ir mais rápido que o outro...a gente tentou ao máximo tentar os dois, mas não dá. A gente não conseguia medir, então a gente jogou um de cada vez. E a gente viu que um voltava com a mesma velocidade que foi, mais ou menos no mesmo tempo, que era o da mola esticada e o outro, o da mola comprimida, voltava mais rápido. Ele ia numa velocidade e voltava mais rápido do que foi.

Então, a gente não levou em consideração, a partir do momento em que a gente jogou um de cada vez, a gente não levou mais em consideração a velocidade dos dois serem a mesma, como eles voltavam.

$26: 16 \quad 26: 18$ 
Professor: como é que vocês queriam demonstrar se estava tendo ou não conservação da quantidade de movimento?

\section{$26: 18 \quad 26: 21$}

Taís: se tivesse conservação, ia bater e parar.

\section{$26: 21 \quad 26: 23$}

Professor: então, se não houvesse conservação, ia bater e parar?

$26: 24 \quad 26: 25$

Taís: é, eu acho que é.

$26: 26 \quad 26: 27$

Professor: se houvesse conservação, ia bater e voltar, é isso?

$26: 28 \quad 26: 29$

Taís: não sei...

$26: 30 \quad 26: 33$

Carina: se houvesse conservação, ia continuar na ... Não, vou falar besteira.

$26: 34 \quad 26: 44$

Professor: eu quero saber o seguinte. Qual foi a idéia, qual foi a hipótese de vocês para usar assim. O carrinho, ele bate... dois carrinhos, vocês usaram dois carrinhos com a mesma massa, só que um estava com a mola estendida e o outro não, não é isso? Lançam os dois carrinhos, teoricamente com a mesma velocidade até que eles batem e voltam. Qual é a comparação que vocês estão fazendo para ver se estava havendo ou não a conservação da quantidade de movimento? Qual foi a hipótese que vocês levantaram?

$26: 45 \quad 26: 48$

Carina: no carrinho que estava com a mola estendida, a velocidade se conservou

$26: 49 \quad 26: 53$

Professor: como você sabe que a velocidade se conservou?

$26: 54 \quad 26: 55$

Carina: a gente fez várias vezes...

$26: 56 \quad 26: 57$

Taís: a gente cronometrou. 
26:58 27:08

Carina: a gente cronometrou e sempre, o carrinho que estava com a mola estendida voltava mais devagar. Então, pelo que a gente observou, ele voltava com a mesma velocidade com que foi.

27:09 27:11

Taís: não era perceptível a diferença.

$27: 12 \quad 27: 15$

Professor: ele ia e voltava no mesmo tempo?

$27: 16 \quad 27: 18$

Carina: é.

$27: 19 \quad 27: 22$

Taís: e o outro ia no mesmo tempo e voltava mais rápido.

$27: 23 \quad 27: 25$

Professor: qual?

$27: 26 \quad 27: 29$

Carina: o de mola comprimida.

$27: 40 \quad 27: 45$

Taís: por causa da energia que estava armazenada na mola que era transferida para o carrinho ele voltava mais rápido.

$27: 46 \quad 27: 48$

Professor: entendi.

$27: 4928: 25$

João: o que estava com a mola esticada amortecia, agora o da comprimida, ele funcionava.

$28: 26 \quad 28: 37$

Professor: como assim?

$28: 38 \quad 29: 46$

João: o que estava com a mola esticada ia em direção e amortecia e o outro não, a mola impulsionava, era mais lento. 
$29: 47 \quad 29: 48$

Professor: voltava mais lento?

$29: 49 \quad 29: 51$

Carina: que o outro.

29:52: $29: 54$

Professor: Em algumas horas, vocês comparam um carrinho com outro e algumas horas, vocês comparam o carrinho com ele mesmo.

29:55 29:57

Carina: é uma variação.

$29: 58 \quad 29: 59$

Professor: tem que ficar claro

$30: 00 \quad 30: 13$

Carina: a gente começou com um por causa da dificuldade de jogar os dois ao mesmo tempo, com a mesma velocidade, com a mesma força.. A gente começou a comparar, na verdade, um com o outro, mas no tempo que ele voltava, independente de como ele voltava e não no tempo que ele voltava. Entendeu?

$30: 14 \quad 30: 15$

Professor: mais ou menos.

$30: 16 \quad 30: 17$

Taís: eu não entendi o que você falou.

$30: 18 \quad 30: 47$

Carina: porque se a gente tivesse jogado os dois com a mesma velocidade, a gente poderia medir o tempo com que eles voltavam, qual chegou mais rápido e qual chegou mais lento. Com a gente não tinha certeza da velocidade, a gente mediu ele com ele mesmo , comparando com o outro. Voltava mais rápido e o outro, não era perceptível a diferença. De vez em quando, a gente percebeu mas não dava para comprovar se era mais lento de verdade.

$30: 48 \quad 31: 04$

Professor: tudo bem. Vamos para o próximo. 
Fernando: nossa pergunta é que ...

$31: 13 \quad 31: 17$

Júlio: com uma régua...

$31: 18 \quad 31: 21$

Professor: marcaram uma distância, é isso?

$31: 21 \quad 31: 27$

Júlio: é.E....funciona com o carrinho.

$31: 28 \quad 31: 53$

Professor: mostrem aí. Peguem a régua lá. Peguem o carrinho. A régua grande, também se vocês quiserem.

$31: 54 \quad 32: 11$

Júlio: o outro carrinho?

$32: 13 \quad 32: 22$

Professor: põe mais no meio, para todo mundo ver.

$32: 23 \quad 33: 28$

Júlio: a gente estava medindo ... a gente impulsionava um carrinho desse que pegava força e esse carrinho batia nesse carrinho e ....antes, a gente fez uma medição que ... os carrinhos, com a mesma força. Ele percorreu um metro em oitenta e três milésimos.

$33: 29 \quad 33: 30$

Francisco: centésimos.

$33: 31 \quad 33: 35$

Júlio: é mesmo, centésimos.

$33: 36 \quad 33: 37$

Francisco: sessenta centésimos.

$33: 38 \quad 33: 40$

Professor: décimos, centésimos...

$33: 41 \quad 33: 49$

Júlio: eu tentei tirar tempo. Tentei três vezes e o carrinho andou cinco metros. 
Jorge: caramba, que ....

$33: 55 \quad 34: 16$

Júlio: aí com a mesma força que ele tinha, impulsionava este carrinho batendo nesse e para comprovar se tinha ou não a conservação de movimento, este carrinho tinha que percorrer a distância de um metro ao mesmo tempo que o outro fez.

$34: 17 \quad 34: 18$

Professor: quando batia, o outro carrinho parava?

$34: 19 \quad 34: 22$

Júlio: a gente não teve tempo de medir.

$34: 23 \quad 34: 24$

Professor: quando este carrinho batia, esse parava?

$34: 25 \quad 34: 26$

Francisco: não.

$34: 27 \quad 34: 30$

Júlio: a gente não teve tempo de fazer.

$34: 31 \quad 34: 49$

Professor: vocês só imaginaram. Então a idéia é que vocês pensaram uma distância, medindo o tempo que este carrinho ia bater. Cronometraram este tempo e ...

$34: 50 \quad 34: 52$

Júlio: o tempo desse aqui até aqui e deste aqui até aqui.

$34: 53 \quad 35: 21$

Professor: mediram a distância e quiseram saber o tempo. Se percorresse ...Se não percorresse, com certeza não tem conservação. Que condição vocês imaginam para o carrinho?

$35: 22 \quad 35: 35$

Francisco: na imaginação, ele tinha que parar.

$35: 36 \quad 35: 38$ 
Professor: a hipótese de vocês é que o primeiro carrinho ia parar?

$35: 39 \quad 35: 40$

Francisco: é.

$35: 41 \quad 35: 42$

Professor: se ele parasse...

$35: 43 \quad 35: 45$

Francisco: a gente ia medir a velocidade porque a massa era igual.

$35: 46 \quad 35: 47$

Professor: e se não parasse?

$35: 48 \quad 35: 53$

Francisco: aí, somava as velocidades ...

$35: 54 \quad 35: 55$

Professor: e como?

$35: 56 \quad 36: 27$

Professor: depois que batesse, a velocidade de um mais a velocidade do outro tinha que dar a velocidade que o outro estava, porque as massas são iguais.

$36: 28 \quad 36: 53$

Francisco: por exemplo, Emília tem três quilos e aí tem a colisão e vão os dois juntos.

$36: 54 \quad 36: 56$

Professor: porque a soma das duas tem que ser oitenta e três, lá da hipótese e vocês garantem que tem conservação?

$36: 57 \quad 37: 06$

Júlio: pela massa.

$37: 07 \quad 37: 17$

Professor: tem mais grupo? Algum grupo não explicou? Então, vamos abrir para discussão.

$37: 18 \quad 39: 21$ 
Taís: A gente lembrou da hipótese. Assim, o que a gente tinha pensado no começo, era que quando uma pessoa, um carro e a frente dele é mais rígida, no impacto, não tem um amortecimento

$39: 22 \quad 39: 24$

Carolina: ou vai para frente ou vai para cima.

$39: 25 \quad 39: 37$

Taís: quando a frente do carro é mais mole, isso amortece

39: $38 \quad 39: 39$

Professor: é o carro que absorve o impacto

$39: 40 \quad 39: 52$

Carina: essa era a nossa idéia, só que a gente não tinha , não sabia como fazer isso, então ele foi se transformando e dando naquilo.

39:53 40:05

Professor: qual que era a proposta? Cada um pensando no experimento que fez. O que a gente queria demonstrar? Se há ou não conservação da quantidade de movimento. Do que depende a quantidade de movimento?

40:06 40:07

Carla: da massa, da velocidade

40:08 40:11

Professor: quais as variáveis que eu tenho que controlar?

$40: 12 \quad 40: 25$

Beatriz: massa

40:26 40:31

Professor: tempo e a distância vocês estão medindo por que? Para achar a velocidade, não é isso? Todos vocês pensaram em maneiras de vocês medirem estas coisas? Como é que vocês constatavam se tinha conservação da quantidade de movimento? As massas tinham que ser iguais?

$40: 32 \quad 41: 35$

Beatriz: não.

41:36 43:20 
Professor: tinha alguma interferência externa ou isso não importa?

$43: 2144: 00$

Tinha. 